Prepared in cooperation with the City of Lincoln, Nebraska, and the Lower Platte South Natural Resources District

\title{
An Assessment of Hydrology, Fluvial Geomorphology, and Stream Ecology in the Cardwell Branch Watershed, Nebraska, 2003-04
}

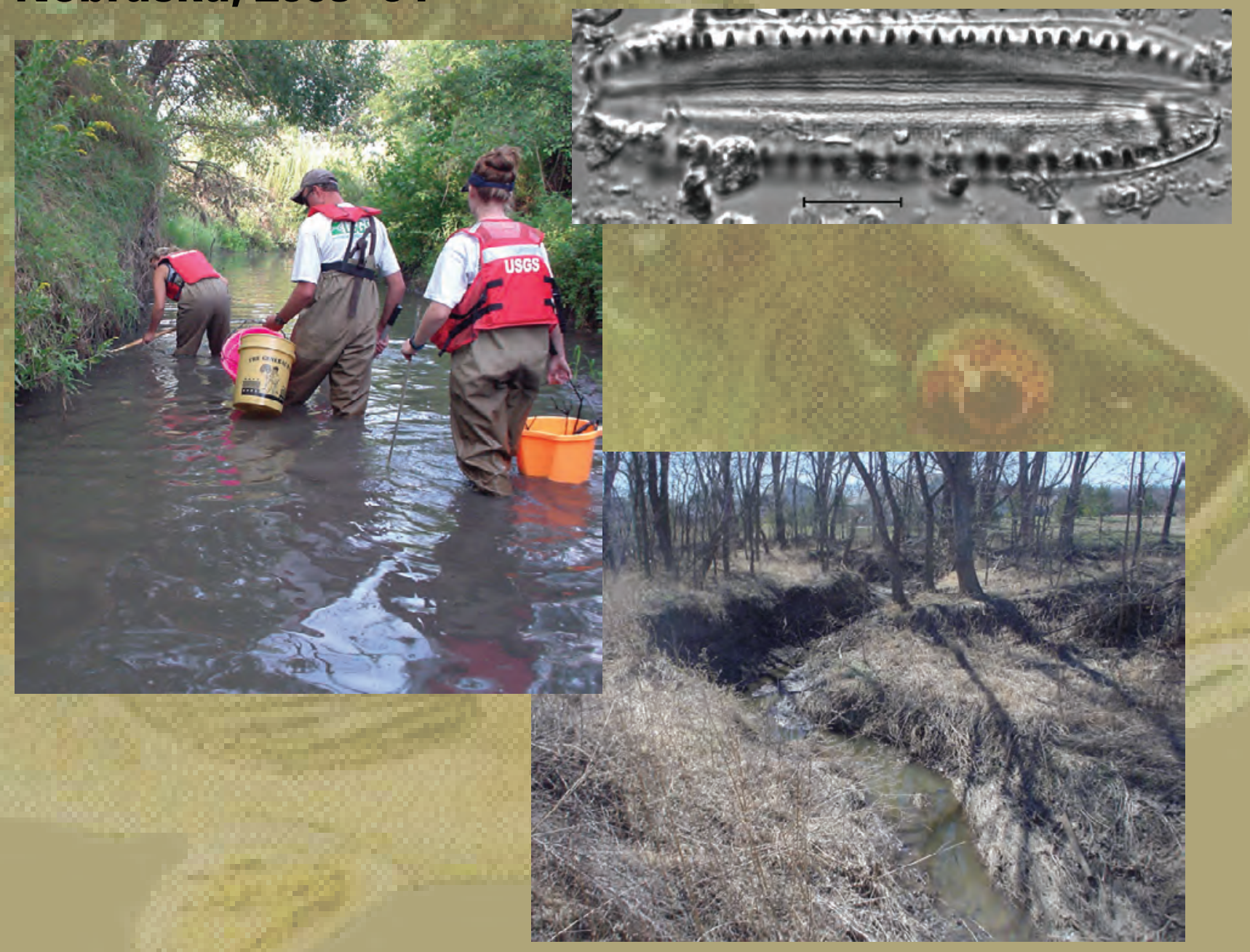

Scientific Investigations Report 2007-5177 


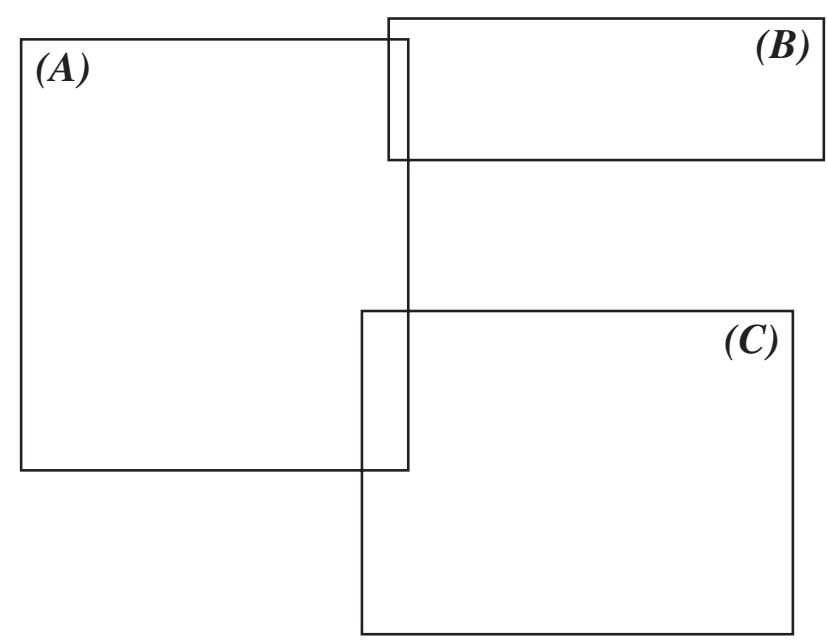

Front cover: (A)U.S. Geological Survey personnel collecting biota from overhanging vegetation habitat. (B) The diatom Nitzschia was collected in Cardwell Branch (photograph by Loren Bahls, Hannae, Helena, Montana). (C) A representative stream channel in the Cardwell Branch watershed. 


\section{An Assessment of Hydrology, Fluvial Geomorphology, and Stream Ecology in the Cardwell Branch Watershed, Nebraska, 2003-04}

By David L. Rus, Benjamin J. Dietsch, Brenda K. Woodward, Beth E. Fry, and Richard C. Wilson

Prepared in cooperation with the

City of Lincoln, Nebraska, and the Lower Platte South Natural Resources District

Scientific Investigations Report 2007-5177 


\section{U.S. Department of the Interior DIRK KEMPTHORNE, Secretary}

\section{U.S. Geological Survey \\ Mark D. Myers, Director}

\section{U.S. Geological Survey, Reston, Virginia: 2007}

For product and ordering information:

World Wide Web: http://www.usgs.gov/pubprod

Telephone: 1-888-ASK-USGS

For more information on the USGS — the Federal source for science about the Earth, its natural and living resources, natural hazards, and the environment:

World Wide Web: http://www.usgs.gov

Telephone: 1-888-ASK-USGS

Any use of trade, product, or firm names is for descriptive purposes only and does not imply endorsement by the U.S. Government.

Although this report is in the public domain, permission must be secured from the individual copyright owners to reproduce any copyrighted materials contained within this report.

Suggested citation:

Rus, D.L., Dietsch, B.J., Woodward, B.K., Fry, B.E., and Wilson, R.C., 2007, An assessment of hydrology, fluvial geomorphology, and stream ecology in the Cardwell Branch watershed, Nebraska, 2003-04: U.S. Geological Survey Scientific Investigations Report 2007-5177, 70 p. 


\section{Contents}

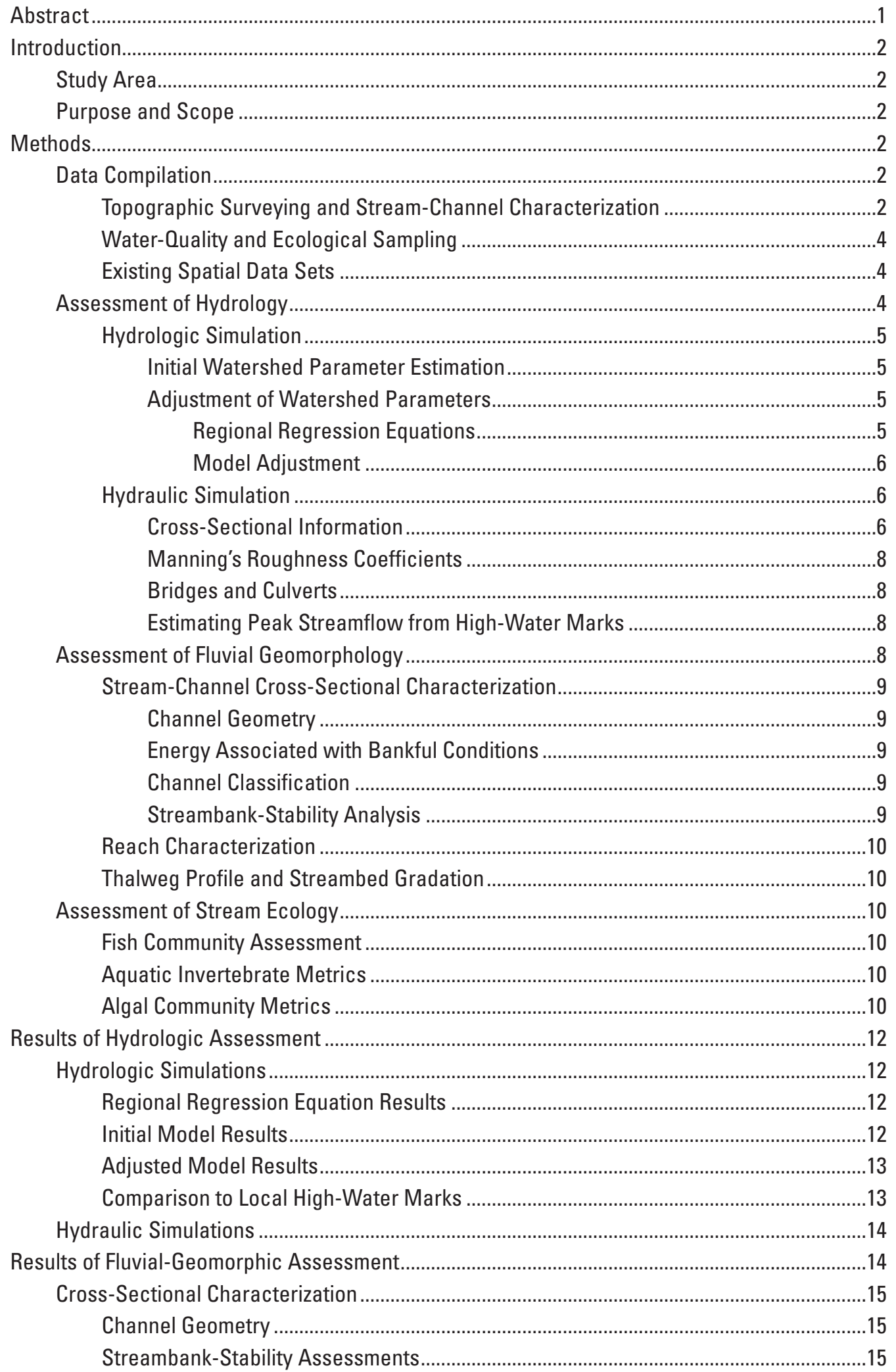




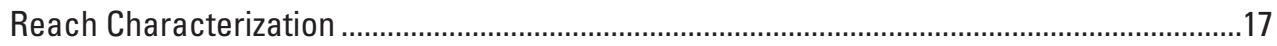

Summary of Cross-Sectional Characterizations ..........................................................17

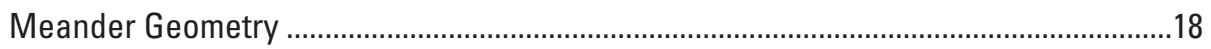

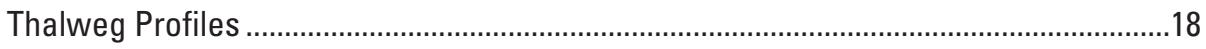

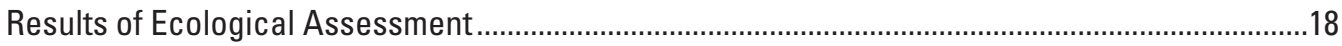

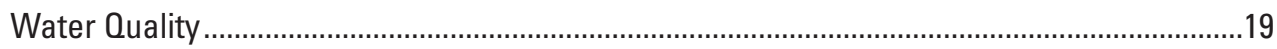

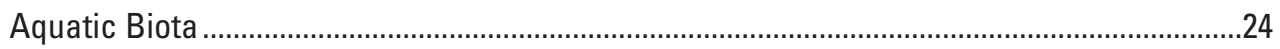

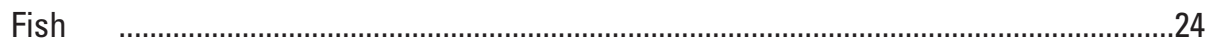

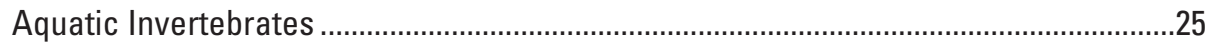

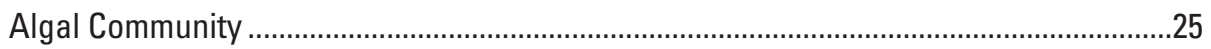

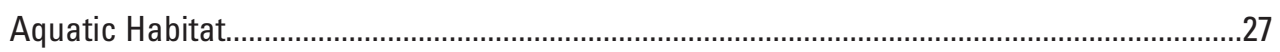

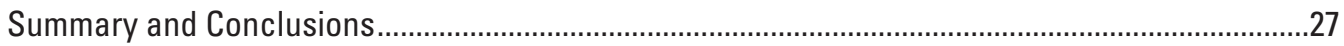

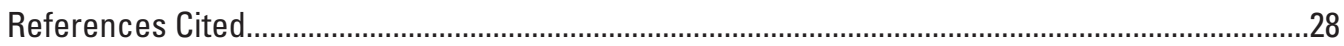

Appendix 1. Channel geometry characteristics for cross sections between November 2003 and March 2004 in the Cardwell Branch study area .............................................................

Appendix 2. Field observations and assessments for cross sections surveyed between November 2003 and March 2004 in the Cardwell Branch study area .................................40

Appendix 3. Classification of channels in the Cardwell Branch study area ....................................44

Appendix 4. Meander geometry measured at selected meanders in the Cardwell Branch

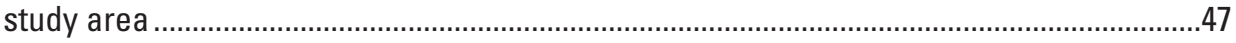

Appendix 5. Water-quality constituents in samples from Cardwell Branch, Nebraska, 2003-04 ..48

Appendix 6. Fish taxa collected at the ecological monitoring site on August 26, 2003, Cardwell

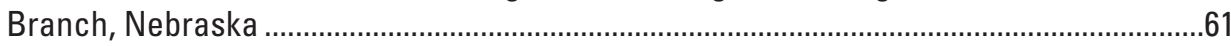

Appendix 7. Aquatic invertebrate taxa collected at the ecological monitoring site on August 26,

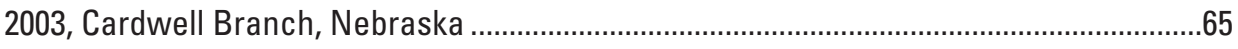

Appendix 8. Algal taxa collected at the ecological monitoring site on August 26, 2003, Cardwell

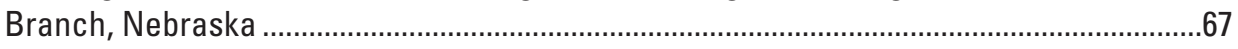

Appendix 9. Potential aquatic habitat observed in the Cardwell Branch study area, 2003-04 ......69

\section{Figures}

1-3. Maps showing:

1. Location of Cardwell Branch watershed and corresponding study area, Lancaster County, Nebraska.

2. Locations where regional regression equations were computed and subwatershed groupings for which the hydrologic model was systematically adjusted, Cardwell Branch watershed

3. Geomorphically distinctive reaches .....................................................................11

4. Photograph of runoff in the Cardwell Branch watershed following an estimated

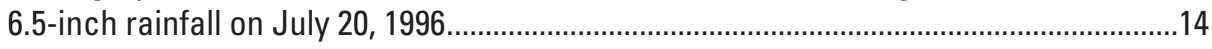

5-7. Graphs showing:

5. Channel geometries observed in the Cardwell Branch watershed in which bankfull geometries were obtained from the field indicators

6. Streambank geometry and bank-failure envelope curves for the Cardwell Branch study area showing threshold values for planar failures and rotational failures... 
7. Meander geometry comparisons for reaches 1, 2, 3, and 4 in the Cardwell Branch study area, Nebraska.....

8. Graphs and photographs showing Thalweg profiles and supporting information for the Cardwell Branch study area, Nebraska.

9. Graphs showing number of fish collected at the Cardwell Branch monitoring site, Nebraska, August 26, 2003

\section{Tables}

1. Regression equations applicable to the Cardwell Branch watershed, Nebraska ............6

2. Basin characteristics of the Cardwell Branch watershed, Nebraska, 2003-04 ...............8

3. Summary of peak streamflow estimates for the Cardwell Branch watershed, Nebraska, 2003-04.

4. Summary of parameter estimates used in the initial hydrologic model of the Cardwell Branch watershed, Nebraska, 2003-04.

5. Systematic adjustments made to selected parameters of the initial hydrologic model for the adjusted hydrologic model of the Cardwell Branch watershed, Nebraska, 2003-04

6. Summary of differences in water-surface elevation estimates derived from the two hydrologic models of the Cardwell Branch watershed, Nebraska, 2003-04.

7. Comparison of thalweg elevations between 1978 and 2003-04 in Cardwell Branch,

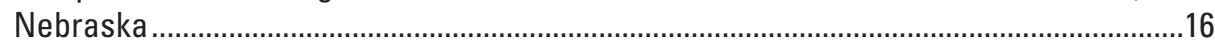

8. Summary of channel geometry in the Cardwell Branch study area, Nebraska...............18

9. Summary of energy terms related to bankfull flows in the Cardwell Branch study area, Nebraska ..18

10. Summary of field assessments in the Cardwell Branch study area, Nebraska...............18

11. Summary of channel classifications in the Cardwell Branch study area, Nebraska......18

12. Summary of meander geometry in the Cardwell Branch study area, Nebraska .............19

13. Summary of field conditions and water properties at the time of sampling at the Cardwell Branch monitoring site, Nebraska, 2003-04.......................................................22

14. Average specific conductance at selected sites near Cardwell Branch, Nebraska......23

15. Summary of selected water-quality constituents at the Cardwell Branch monitoring site, Nebraska, 2003-04

16. Richness metrics associated with aquatic invertebrates sampled from the Cardwell Branch monitoring site, Nebraska, August 26, 2003

17. Summary of algal metrics determined for Cardwell Branch monitoring site, Nebraska, August 26, 2003.

18. Summary of aquatic habitat inventory in the Cardwell Branch study area, Nebraska, 2003-04 


\section{Conversion Factors, Abbreviations, and Datums}

\begin{tabular}{|c|c|c|}
\hline Multiply & By & To obtain \\
\hline \multicolumn{3}{|c|}{ Length } \\
\hline inch (in.) & 2.54 & centimeter $(\mathrm{cm})$ \\
\hline foot $(\mathrm{ft})$ & 0.3048 & meter $(\mathrm{m})$ \\
\hline mile (mi) & 1.609 & kilometer (km) \\
\hline \multicolumn{3}{|c|}{ Slope } \\
\hline foot per foot $(\mathrm{ft} / \mathrm{ft})$ & 1 & meter per meter $(\mathrm{m} / \mathrm{m})$ \\
\hline foot per mile ( $\mathrm{ft} / \mathrm{mi})$ & 0.1894 & meter per kilometer $(\mathrm{m} / \mathrm{km})$ \\
\hline \multicolumn{3}{|c|}{ Area } \\
\hline acre & 0.4047 & hectare (ha) \\
\hline square mile $\left(\mathrm{mi}^{2}\right)$ & 2.590 & square kilometer $\left(\mathrm{km}^{2}\right)$ \\
\hline \multicolumn{3}{|c|}{ Volume } \\
\hline gallon (gal) & 3.785 & liter $(\mathrm{L})$ \\
\hline million gallons (Mgal) & 3,785 & cubic meter $\left(\mathrm{m}^{3}\right)$ \\
\hline \multicolumn{3}{|c|}{ Flow rate } \\
\hline foot per second (ft/s) & 0.3048 & meter per second $(\mathrm{m} / \mathrm{s})$ \\
\hline cubic foot per second $\left(\mathrm{ft}^{3} / \mathrm{s}\right)$ & 0.02832 & cubic meter per second $\left(\mathrm{m}^{3} / \mathrm{s}\right)$ \\
\hline inch per hour (in/h) & 0.0254 & meter per hour $(\mathrm{m} / \mathrm{h})$ \\
\hline \multicolumn{3}{|c|}{ Pressure } \\
\hline $\begin{array}{l}\text { pound-force per square inch } \\
\left(\left(\mathrm{lbf} / \mathrm{in}^{2}\right)\right.\end{array}$ & 6.895 & kilopascal (kPa) \\
\hline pound per square foot $\left(\mathrm{lb} / \mathrm{ft}^{2}\right)$ & 0.04788 & kilopascal (kPa) \\
\hline pound per square inch $\left(\mathrm{lb} / \mathrm{in}^{2}\right)$ & 6.895 & kilopascal $(\mathrm{kPa})$ \\
\hline \multicolumn{3}{|c|}{ Density } \\
\hline pound per cubic foot $\left(\mathrm{lb} / \mathrm{ft}^{3}\right)$ & 16.02 & kilogram per cubic meter $\left(\mathrm{kg} / \mathrm{m}^{3}\right)$ \\
\hline \multicolumn{3}{|c|}{ Power } \\
\hline $\begin{array}{l}\text { pound per foot per second } \\
{[(\mathrm{lb} / \mathrm{ft}) / \mathrm{s}]}\end{array}$ & 1.356 & watt (W) \\
\hline
\end{tabular}

Temperature in degrees Celsius $\left({ }^{\circ} \mathrm{C}\right)$ may be converted to degrees Fahrenheit $\left({ }^{\circ} \mathrm{F}\right)$ as follows:

$$
{ }^{\circ} \mathrm{F}=\left(1.8 x^{\circ} \mathrm{C}\right)+32 .
$$

Vertical coordinate information is referenced to the North American Vertical Datum of 1988 (NAVD 88).

Horizontal coordinate information is referenced to the North American Datum of 1983 (NAD 83).

Specific conductance is given in microsiemens per centimeter at 25 degrees Celsius $(\mu \mathrm{S} / \mathrm{cm}$ at $\left.25^{\circ} \mathrm{C}\right)$.

Concentrations of chemical constituents in water are given either in milligrams per liter (mg/L) or micrograms per liter $(\mu \mathrm{g} / \mathrm{L})$. 


\section{Acronyms Used in Report}

\begin{tabular}{|c|c|}
\hline BOD & biochemical oxygen demand \\
\hline BS & basin slope \\
\hline CDA & contributing drainage area \\
\hline COD & chemical oxygen demand \\
\hline DEM & digital elevation model \\
\hline DO & dissolved oxygen \\
\hline DTM & digital terrain model \\
\hline $\mathrm{E}$ & estimated value \\
\hline EPT & Ephemeroptera, Plecoptera, and Trichoptera, combined \\
\hline GPS & global positioning system \\
\hline HEC-HMS & $\begin{array}{l}\text { Hydraulic Engineering Center-Hydrologic Modeling System (U.S. } \\
\text { Army Corps of Engineers) }\end{array}$ \\
\hline HEC-RAS & $\begin{array}{l}\text { Hydraulic Engineering Center-River Analysis System (U.S. Army } \\
\text { Corps of Engineers) }\end{array}$ \\
\hline HWM & high-water mark \\
\hline LIDAR & light detection and ranging \\
\hline NAD 83 & North American Datum of 1983 \\
\hline NAVD 88 & North American Vertical Datum of 1988 \\
\hline NPDES & National Pollution Discharge Elimination System \\
\hline NTRU & nephelometric turbidity ratio unit \\
\hline NURP & National Urban Runoff Program \\
\hline NWQL & National Water Quality Laboratory (Lakewood, Colorado) \\
\hline $\mathrm{PAH}$ & polycyclic aromatic hydrocarbons \\
\hline PLP & permeability of the least permeable layer \\
\hline $\mathrm{RC}$ & radius of curvature \\
\hline SCS & Soil Conservation Service \\
\hline SEP & standard error of prediction \\
\hline SS & suspended sediment \\
\hline SSURGO & Soil Survey Geographic Database \\
\hline TIN & triangulated irregular network \\
\hline TSDN & Technical Support Data Notebook \\
\hline TSS & total suspended solids \\
\hline USGS & U.S. Geological Survey \\
\hline $\mathrm{W}: \mathrm{D}$ & width-to-depth ratio \\
\hline WSE & water-surface elevation \\
\hline XSID & cross-section identifier \\
\hline
\end{tabular}




\title{
An Assessment of Hydrology, Fluvial Geomorphology, and Stream Ecology in the Cardwell Branch Watershed, Nebraska, 2003-04
}

\author{
By David L. Rus, Benjamin J. Dietsch, Brenda K. Woodward, Beth E. Fry, and Richard C. Wilson
}

\section{Abstract}

An assessment of the 16.3-square-mile Cardwell Branch watershed characterized the hydrology, fluvial geomorphology, and stream ecology in 2003-04. The study-performed by the U.S. Geological Survey in cooperation with the City of Lincoln, Nebraska, and the Lower Platte South Natural Resources District-focused on the 7.7-square-mile drainage downstream from Yankee Hill Reservoir.

Hydrologic and hydraulic models were developed using the Hydrologic Modeling System (HEC-HMS) and River Analysis System (HEC-RAS) of the U.S. Army Corps of Engineers Hydraulic Engineering Center. Estimates of streamflow and water-surface elevation were simulated for 24-hour-duration design rainstorms ranging from a 50-percent frequency to a 0.2-percent frequency. An initial HEC-HMS model was developed using the standardized parameter estimation techniques associated with the Soil Conservation Service curve number technique. An adjusted HEC-HMS model also was developed in which parameters were adjusted in order for the model output to better correspond to peak streamflows estimated from regional regression equations. Comparisons of peak streamflow from the two HEC-HMS models indicate that the initial HEC-HMS model may better agree with the regional regression equations for higher frequency storms, and the adjusted HEC-HMS model may perform more closely to regional regression equations for larger, rarer events. However, a lack of observed streamflow data, coupled with conflicting results from regional regression equations and local high-water marks, introduced considerable uncertainty into the model simulations. Using the HEC-RAS model to estimate water-surface elevations associated with the peak streamflow, the adjusted HEC-HMS model produced average increases in water-surface elevation of $0.2,1.1$, and 1.4 feet for the 50-, 1-, and 0.2-percent-frequency rainstorms, respectively, when compared to the initial HEC-HMS model.

Cross-sectional surveys and field assessments conducted between November 2003 and March 2004 indicated that Cardwell Branch and its unnamed tributary appear to be undergoing incision (the process of downcutting) (with three locations showing 2 or more feet of streambed incision since 1978) that is somewhat moderated by the presence of grade controls and vegetation along the channel profile. Although streambank failures were commonly observed, 96 percent of the surveyed cross sections were classified as stable by planar and rotational failure analysis - a disconnect that may have been the result of assumed soil properties. Two process-based classification systems each indicated that the reaches within the study area were incising and widening, and the Rosgen classification system characterized the streams as either type E6 or B6c. E6 channels are hydraulically efficient with low width-depth ratios, low to moderate sinuosity, and gentle to moderately steep slopes. B6c channels typically are incised with low width-depth ratios maintained by riparian vegetation, low bedload transport, and high washload transport. No obvious nickpoints (interruption or break in slope) were observed in the thalweg profile (line of maximum streambed descent), and the most acute incision occurred immediately downstream from bridges and culverts.

Nine water-quality samples were collected between August 2003 and November 2004 near the mouth of the watershed. Sediment-laden rainfall-runoff substantially affected the water quality in Cardwell Branch, leading to greater biochemical and chemical oxygen demands as well as increased concentrations of several nutrient, bacteriological, sediment, and pesticide constituents. The storage of rainfall runoff in Yankee Hill Reservoir may prolong the presence of runoff-related constituents downstream.

Across the study area, there was a lack of habitat availability for aquatic biota because of low dissolved oxygen levels and low streamflows or dry channels. In August 2003, the aquatic community near the mouth of the stream was represented by undernourished fish, pollution-tolerant Dipteran invertebrates, and pollution-tolerant, autotrophic algae. The combined effect of exposure to rainfall-runoff and a lack of available habitat may be contributing to the degraded aquatic communities observed at the monitoring site. 


\section{Introduction}

As rural watersheds adjacent to metropolitan growth areas become urbanized, changes occur that affect the flooding, stream-channel geometry, and ecological characteristics of those watersheds. Increases in the magnitude and frequency of flooding caused by urbanization are well documented and occur through the loss of rainfall storage and an increase in hydraulic efficiency of stormwater conduits (Hollis, 1975; Chow and others, 1988; Konrad, 2003; Fitzpatrick and others, 2004). The altered streamflow characteristics also expose stream channels to erosive velocities more frequently and can lead to unstable geomorphic conditions such as channel incision, widening, or sedimentation (Hammer, 1972; Booth, 1990; Booth and Jackson, 1997; Bledsoe and Watson, 2001; Fitzpatrick and others, 2004). The effect of urbanization on the flow regime can affect the integrity of an aquatic ecosystem through the loss of habitat, alterations to in-stream energy fluxes, disturbed interactions of the biota, and effects on stream chemistry (Karr, 1991; Poff and others, 1997; Fitzpatrick and others, 2004; Krause and others, 2004).

As the Cardwell Branch watershed becomes urbanized, changes to the stream system may occur in the form of increased flooding, reduced stream-channel stability, and ecological degradation. An understanding of the conditions prior to urbanization should be known in order to detect those changes (Wohl and others, 2005). To address this need, the U.S. Geological Survey (USGS), in cooperation with the City of Lincoln and the Lower Platte South Natural Resources District, performed an assessment of the 7.7- $\mathrm{mi}^{2}$ area of the Cardwell Branch watershed located downstream from Yankee Hill Reservoir.

\section{Study Area}

Cardwell Branch watershed is one such watershed where urban development is planned (fig. 1). Located near Lincoln, Nebraska, a community of 226,062 (U.S. Census Bureau, 2005), the 16.3- $\mathrm{mi}^{2}$ watershed is drained by Cardwell Branch, which includes the $8.6 \mathrm{mi}^{2}$ draining into Yankee Hill Reservoir, and an unnamed tributary that drains approximately $3.0 \mathrm{mi}^{2}$. Streams in the watershed, with the exception of a perennial section of Cardwell Branch downstream from Yankee Hill Reservoir, are classified as ephemeral on 1:24,000scale topographic quadrangle maps of the USGS, although base flow near the mouth of the watershed was observed to be on the order of $0.01 \mathrm{ft}^{3} / \mathrm{s}$ during the assessment period of 2003-04. The watershed is characterized by loess soils (Soil Conservation Service, 1993) and is part of the Nebraska and Kansas Loess-Drift Hills major land resource area (Soil Conservation Service, 1981) and the Loess and Glacial Drift Hills of the Western Corn Belt Plains level III ecoregion (Omernick, 1987). Land was used primarily for nonirrigated agricultural purposes in 2003. However, some urban development has occurred in the eastern parts of the watershed, and additional development is planned through 2030 (City of Lincoln, 2005). The study area focuses on the part of the watershed where development is anticipated and consists of the watershed downstream from Yankee Hill Reservoir, including the unnamed tributary (fig. 1).

\section{Purpose and Scope}

The purpose of this report is to present and discuss the results of an assessment of the hydrology, fluvial geomorphology, and stream ecology in the Cardwell Branch watershed during 2003-04. Peak streamflows and water-surface elevations corresponding to design rainfall events of varying magnitude are described. Field surveys and historical comparisons provide the context for the fluvial geomorphic assessment. Finally, water-quality and ecological data that were collected and compiled for this study are used to assess the stream ecology in the Cardwell Branch.

\section{Methods}

\section{Data Compilation}

Data used in the assessment were derived from information collected in the field as well as from existing data sets. Topographic surveys were performed at 134 cross sections, and ecological data were collected near the mouth of the watershed. Spatially referenced data sets of land use, topography, soil type, and hydrography were obtained from several sources and were used primarily to develop analytical models for the watershed.

\section{Topographic Surveying and Stream-Channel Characterization}

The stream channel and adjacent flood plain were surveyed at 134 cross sections in the study area during the winterspring of 2003-04. Stream distances between cross sections were limited to $800 \mathrm{ft}$ or less, where possible, along Cardwell Branch downstream from Yankee Hill Reservoir and along the unnamed tributary (fig. 1).

Topographic surveys were performed using real-time kinematic global positioning system (GPS) techniques (U.S. Army Corps of Engineers, 2003) in tandem with total station or digital level surveying techniques (U.S. Army Corps of Engineers, 1994). The survey data were referenced to the North American Vertical Datum of 1988 (NAVD 88) and the North American Datum of 1983 (NAD 83) using StatePlane coordinates and a benchmark established for the study at Yankee Hill Reservoir.

Some basic stream-channel characterization was done at each cross section in addition to collecting the survey data. Photographs were taken, and Manning's roughness values 


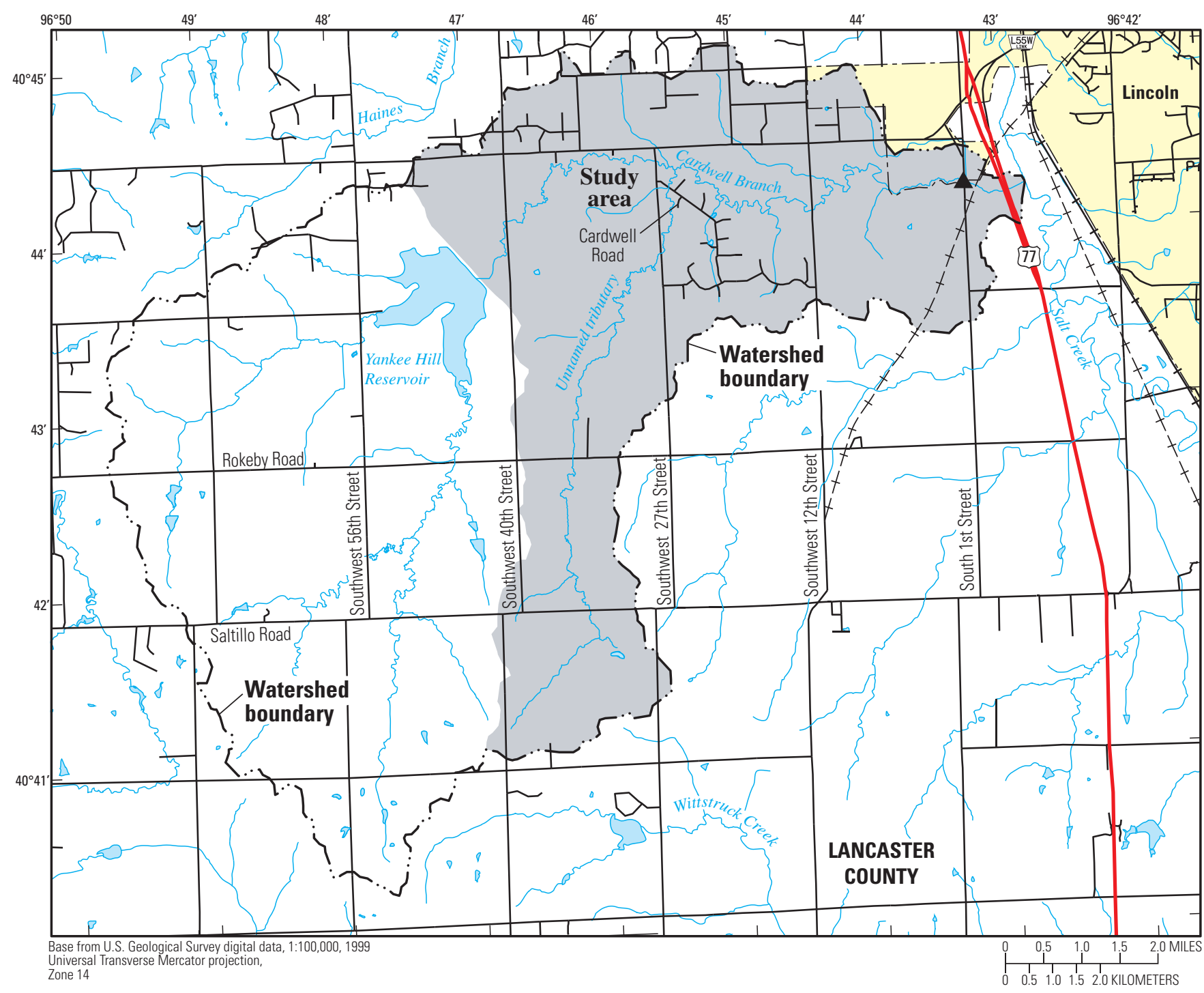

Horizontal coordinate information is referenced to the North American Datum of 1983 (NAD 83)

\section{EXPLANATION}

A Monitoring site

06803500 U.S. Geological Survey streamflowgaging station and number (see index map)

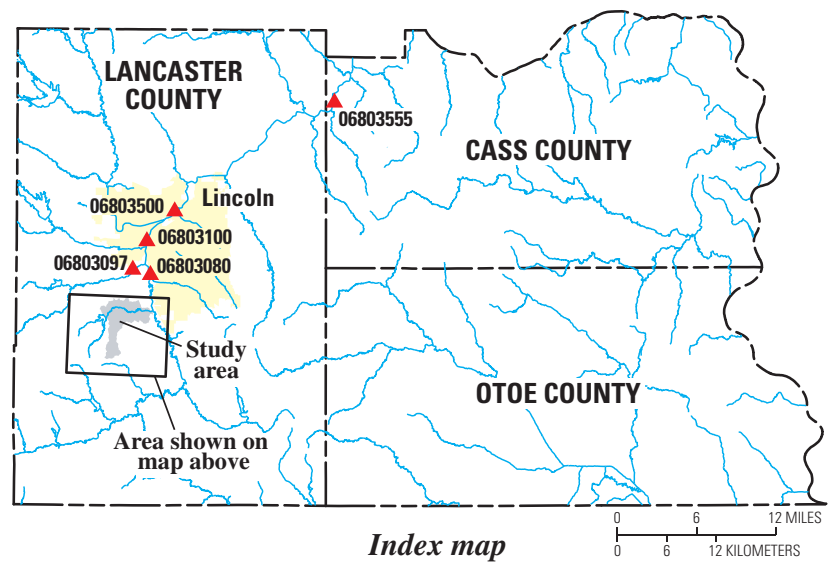

Figure 1. Location of Cardwell Branch watershed and corresponding study area, Lancaster County, Nebraska. 
were estimated for the stream channel and the flood plain using the modified Cowan (1956) method listed in Arcement and Schneider (1989). Characterization of the geomorphic condition included: the identification of bankfull (as indicated by geomorphic indicators) using the methods of Fitzpatrick and others (1998); the determination of the stage of channel evolution as defined by Simon (1989); the planform flow condition (meander, cross-over, or straight); flow type (riffle, run, pool, backwater, or dry); whether or not tree roots appeared to be stabilizing the streambanks; the presence of mass-waste failures; the presence of toe erosion; the presence of sand in the streambed (to provide evidence of sediment deposition); and the streambed and streambank material. The land use (crops, pasture, woodland, grassland, or residential) in the riparian area adjacent to the stream was classified. Aquatic habitat (woody debris, overhanging vegetation, undercut streambanks, aquatic macrophytes, artificial habitat, or none) was identified at the midpoint and each edge of the low-water channel.

\section{Water-Quality and Ecological Sampling}

A monitoring site near the mouth of the watershed (located at the South 1st Street bridge over Cardwell Branch; USGS station identification number 404413096431401) was selected for water-quality and detailed ecological assessment (fig. 1). Water-quality data were collected approximately $100 \mathrm{ft}$ downstream from the bridge; whereas, the ecological assessment data were collected $330 \mathrm{ft}$ upstream from the bridge to avoid bridge effects on the aquatic communities.

Nine water samples were collected from flowing sections of the stream between August 2003 and November 2004 following the standard procedures of the USGS (U.S. Geological Survey, variously dated). Sampling frequency was designed to target a range of streamflows as well as a range of climatic conditions. Cardwell Branch was in a backwater condition at the monitoring site during one runoff event on May 24, 2004, because of corresponding streamflow in Salt Creek, and therefore a water sample was collected at the next bridge upstream, located on Southwest 12th Street. Streamflow (measured using either a Parshall flume or a type AA velocimeter), specific conductance, $\mathrm{pH}$, water temperature, turbidity, and dissolved oxygen data were collected onsite for each sample. All samples were analyzed for concentrations of chemical oxygen demand (Fishman and Friedman, 1989), 5-day biochemical oxygen demand (American Public Health Association, 1980), major ions (Fishman and Friedman, 1989), nutrients (Fishman, 1993), arsenic (Fishman and Friedman, 1989), organic pesticides (Zaugg and others, 1995), organic chemicals associated with wastewater (Zaugg and others, 2002), and total suspended solids (Fishman and Friedman, 1989). A subset of sample concentrations were determined for dissolved metals (Fishman and Friedman, 1989), Escherichia coli (E. coli) (U.S. Environmental Protection Agency, 2002), oil and grease (U.S. Environmental Protection Agency, 1999), and polyaromatic hydrocarbons (Fishman, 1993). All constituents were analyzed by the USGS National Water Quality Laboratory (NWQL, Lakewood, Colorado) with the exception of biochemical-oxygen demand (which was analyzed at Severn-Trent Laboratory, Denver, Colorado) and E. coli (which was analyzed by USGS field personnel).

Ecological sampling of the aquatic system was performed August 26, 2003, on a 500-ft-long stream reach that ended $330 \mathrm{ft}$ upstream from the monitoring site. An aquatic habitat assessment was done using the procedures of Fitzpatrick and others (1998). Qualitative sampling (in which samples from multiple habitats are composited together) of the benthic invertebrate and algal communities followed the procedures of Moulton and others (2002) and included all available aquatic habitats (overhanging vegetation, undercut banks, woody debris, and streambed sediment) within the reach to best characterize the taxonomic richness of the biota. Because richness was the indicator targeted in this study, rather than abundance, future assessments using similar collection techniques can be compared to this initial baseline data using coefficients of similarity such as the Jaccard or Sorensen coefficients (Cuffney, 2003).

Identification of algal taxa was performed by Dr. Loren Bahls (a phycologist at Hannaea, Helena, Montana) following the protocols of Charles and others (2002). Identification of benthic invertebrate taxa was done by the USGS NWQL following the protocols of Moulton and others (2000). The fish taxa in the reach were identified and enumerated by USGS field personnel using nonlethal techniques described in Moulton and others (2002).

\section{Existing Spatial Data Sets}

Existing data useful to this study were compiled from several sources. Land-use data were based on property-zoning maps provided by the City of Lincoln in November 2003. Soil classification data were taken from the Soil Survey Geographic Database (SSURGO) for Lancaster County, Nebraska (Natural Resources Conservation Service, 1999). Topographic data collected using light detection and ranging (LIDAR) techniques were obtained from the City of Lincoln in 2005.

\section{Assessment of the Hydrology}

Watershed hydrology was assessed to characterize the effects of runoff. A hydrologic model was developed for the entire watershed that estimated peak streamflows $\left(\mathrm{Q}_{p}\right)$ caused by design rainfall events of varying magnitude. A hydraulic model was developed for the study area that estimated the water-surface elevation (WSE) corresponding to each $\mathrm{Q}_{p}$ estimate. 


\section{Hydrologic Simulation}

Determinations of streamflow corresponding to rainfall in the Cardwell Branch watershed were made using the Hydraulic Engineering Center, Hydrologic Modeling System (HEC-HMS) (version 2.2.2) (U.S. Army Corps of Engineers, 2001) in conjunction with spatially referenced data sets. The model consisted of five analytical components: (1) a meteorologic component that applied rainfall to the model; (2) a topographic component that determined watershed boundaries and flow paths; (3) a loss component that determined excess rainfall as a function of soil-infiltration capacity; (4) a transform component that accounted for the traveltime for runoff to reach the stream channel; and (5) a routing component that computed the traveltime of runoff in the stream-channel system.

Design rainfall data for the 50-, 20-, 10-, 2-, 1-, and 0.2percent-frequency storms over a 24-hour duration were used to simulate the corresponding $\mathrm{Q}_{p}$. The $\mathrm{Q}_{p}$ was determined by simulating a 24-hour duration design rainfall magnitude distributed over a Soil Conservation Service (SCS) type-2 storm distribution (Soil Conservation Service, 1986). The magnitudes of the 24-hour duration, 50-, 20-, 10-, 2-, and 1-percentfrequency storms were $3.00,3.93,4.69,6.00$, and 6.68 in., respectively, for the study area (Hershfield, 1961). The magnitude of the 0.2-percent frequency storm was extrapolated from the Hershfield (1961) data set using a logarithmic regression, which produced a storm total of $8.2 \mathrm{in}$. Additionally, local rainfall data were obtained from a rain gage at Salt Creek at Pioneers Boulevard (USGS station 06803080) that was $5 \mathrm{mi}$ northeast of the watershed centroid.

The GeoHMS extension of ArcView ${ }^{\mathrm{TM}} 3.3$ (Doan, 2000) was used to characterize watershed boundaries and streamflow paths. A hydrologically corrected (Saunders, 2000) digital elevation model (DEM) with 33-ft grid spacing was used to represent the land surface. Streams were assigned at points within the watershed having a drainage area of $0.25 \mathrm{mi}^{2}$ or greater. Subwatersheds were then automatically delineated from stream junctions and from manually selected points of interest such as bridges or culverts. This resulted in a total of 48 subwatersheds with an average drainage area of $0.34 \mathrm{mi}^{2}$ (218 acres).

\section{Initial Watershed Parameter Estimation}

The initial parameters that characterized the watershed within the model were estimated using the techniques outlined in SCS Technical Release 55 (TR-55) (Soil Conservation Service, 1986) to maintain consistency with models developed for nearby watersheds (Olsson Associates and Wright Water Engineers, 2000; Camp, Dresser, and McKee, Inc., 2005). Excess rainfall was computed using the SCS curve number technique, and the transformation of that rainfall to the mouth of each subwatershed was determined using the SCS unit hydrograph technique. Runoff from each of the sub-watersheds then was routed through the watershed using Muskingum-Cunge techniques (Cunge, 1969) in the river channels and level-pool techniques (Chow and others, 1988) in the reservoir. The model required an initial WSE for Yankee Hill Reservoir. This was assumed to be at the lowest opening of the spillway $(1,237 \mathrm{ft}$ above NAVD 88$)$ for all simulations except the 1 - and 0.2-percent-frequency rainstorms. A "worse" condition was assumed for these two storms in which the WSE was $20 \mathrm{ft}$ above the lowest opening, which was still $5 \mathrm{ft}$ lower than the opening to the emergency spillway. More detailed descriptions of the initial parameter estimation are given in the 2005 Technical Support Data Notebook (TSDN) for the Cardwell Branch Watershed, Lancaster County, Nebraska, which is on file at the City of Lincoln and in review with the Federal Emergency Management Agency.

\section{Adjustment of Watershed Parameters}

Because the Cardwell Branch watershed is ungaged, there was a large amount of uncertainty associated with $\mathrm{Q}_{p}$ values obtained from the uncalibrated model simulations (Zarriello, 1998). Therefore, comparisons of the modeled $\mathrm{Q}_{p}\left(\mathrm{Q}_{p H M S}\right)$ values were made to $Q_{p}$ estimates obtained using regional regression equations $\left(\mathrm{Q}_{p \text {-regression }}\right)$. The watershed parameters then were adjusted in HEC-HMS until the $\mathrm{Q}_{p H м S}$ values corresponded to within one standard error of the $\mathrm{Q}_{\text {p-regression }}$ values. When historical high-water marks (HWMs) were available, those marks were compared to $\mathrm{Q}_{p H M S}$ as independent substantiation of the model.

\section{Regional Regression Equations}

The regional regression equations of Soenksen and others (1999) were used for comparative purposes with the HECHMS model. These equations not only offered the advantage of characterizing uncertainty through the standard error of prediction but also were the most current USGS regional regression equations available. $\mathrm{Q}_{\text {p-regression }}$ estimates using Soenksen and others (1999) were compared with similar estimates derived from the older equations of Beckman and Hutchison (1962) and Cordes and Hotchkiss (1993) and were judged to be similar. Though not available when the model was being developed, the recent equations of Strahm and Admiraal (2005) also can provide comparative estimates of $\mathrm{Q}_{p}$

$\mathrm{Q}_{\text {p-regression }}$ equations were selected for the 50-, 1-, and 0.2 -percent-frequency streamflows (table 1 ) and applied at six locations within the watershed (fig. 2) that represented large changes in the drainage area. The basin characteristics used in the equations were contributing drainage area, basin slope, and the permeability of the least permeable layer (table 2). To ensure the applicability of the equations, the same basin-characteristic data sets used to develop the equations by Soenksen and others (1999) were used to compute $\mathrm{Q}_{\text {p-regression. }}$. The Yankee Hill Reservoir drainage area was excluded from the computation of basin characteristics for downstream sites to account for the peak-attenuating effect of the reservoir. An additional 70, 130, and $130 \mathrm{ft}^{3} / \mathrm{s}$ (based on the design characteristics for the reservoir outflow) were added to the $\mathrm{Q}_{\text {p-regression }}$ 
Table 1. Regression equations applicable to the Cardwell Branch watershed, Nebraska.

[SEP, standard error of the prediction; $\mathrm{Q}_{X X \%}$, peak discharge, in cubic feet per second, for a given percentage frequency; CDA, contributing drainage area, in square miles; BS, basin slope, in feet per mile; PLP, permeability of the least permeable layer, in inches per hour; from Soenksen and others, 1999]

\begin{tabular}{lc}
\hline \multicolumn{1}{c}{ Equation } & $\begin{array}{c}\text { SEP, based on } \\
\text { variables in } \log _{10} \\
\text { units }\end{array}$ \\
\hline$Q_{50 \%}=5.70 C D A^{0.558} B S^{0.655} P L P^{-0.470}$ & 0.206 \\
$Q_{1 \%}=242 C D A^{0.485} B S^{0.349} P L P^{-0.474}$ & .140 \\
$Q_{0.2 \%}=650 C D A^{0.465} B S^{0.260} P L P^{-0.417}$ & .163 \\
\hline
\end{tabular}

values for the 50-, 1-, and 0.2-percent frequency streamflows, respectively, for those downstream sites. This seemed most appropriate for obtaining reasonable $\mathrm{Q}_{p \text {-regression }}$ values. It is possible, though, that exclusion of the area upstream from the reservoir may still have had unintended effects on the applicability of the regression equations.

\section{Model Adjustment}

Certain watershed parameters were adjusted manually within HEC-HMS to allow the $\mathrm{Q}_{p H M S}$ values to better match the $\mathrm{Q}_{\text {p-regression }}$ values. The parameters that were adjusted included: the curve number and initial abstraction to adjust the amount of excess rainfall available; the lag time to adjust the shape of the unit hydrograph for each subwatershed; and the roughness values (in the channel and each flood plain) to adjust the level of attenuation within each routing reach.

A parameter that was not adjusted was the magnitude of each design rainfall event. This was because the model was extremely sensitive to the rainfall inputs, and in lieu of observed-streamflow data, standard practice is to assume that the frequency of the rainfall event corresponds to the frequency of the peak streamflow (Federal Emergency Management Agency, 2003). This is an assumption made out of necessity and may be problematic. Additional uncertainty is introduced by the historical nature of the rainfall frequency magnitudes that were developed from rainfall data through 1961 (Hershfield, 1961). The magnitudes as well as typical design hyetographs are currently being updated for the Nation (National Weather Service, 2006) but were not available for this investigation.

These adjustments were done systematically for all subwatersheds and stream reaches that were within each of four groupings of the subwatersheds that corresponded to the six locations where $\mathrm{Q}_{p \text {-regression }}$ was computed (fig. 2). No comparisons between $\mathrm{Q}_{p H M S}$ and $\mathrm{Q}_{p \text {-regression }}$ at the mouth of the watershed (site F, fig. 2) were used in the adjustment process because the effect of a highly meandering section of Cardwell Branch just downstream from its confluence with the unnamed tributary was not adequately characterized by the regression equations. Such a section was expected to attenuate peak discharge to a greater extent than was characterized by the regression equations.

\section{Hydraulic Simulation}

Hydraulic analyses were performed on study area streams with a drainage area greater than $1 \mathrm{mi}^{2}$. These analyses determined the WSE associated with storms of 50-, 20-, 10-, 2-, 1-, and 0.2-percent frequency.

WSEs were determined using the Hydraulic Engineering Center River Analysis System (HEC-RAS) (version 3.1.2) (U.S. Army Corps of Engineers, 2002). This one-dimensional steady-state model uses standard step-backwater analyses to compute the WSE at each cross section and assumes steady, subcritical, gradually varying flow conditions. Inputs to the model included field-surveyed cross sections supplemented with topographic data, measurements of bridge properties, field measurements of Manning's roughness, identification of areas of ineffective flow, and discharge data (as computed from the hydrologic simulations). Downstream boundary conditions were based on the most recent published WSE of Salt Creek at the Cardwell Branch confluence (Federal Emergency Management Agency, 2001). For example, a 1-percent frequency flood produced a Salt Creek WSE of 1,176.5 ft above NAVD 88, which created backwater conditions in the downstream reaches of Cardwell Branch. A streambed slope of $0.0017 \mathrm{ft} / \mathrm{ft}$ was applied to normal depth equations to compute the starting WSE at the most downstream cross section in Cardwell Branch.

\section{Cross-Sectional Information}

The HEC-RAS model was applied at 137 cross sections, including 12 sets (two cross sections upstream and two downstream) corresponding to bridges and culverts in the study area. Each cross section was characterized using channel geometry, Manning's roughness coefficients, and ineffective flow areas.

Cross-sectional geometry was generated from a digital terrain model (DTM) using the HEC-GeoRAS ArcView ${ }^{\text {TM }}$ extension. The DTM was based on a triangulated irregular network (TIN) of surveyed cross-sectional data points and the best available topographic data, which are documented in the "Data Compilation" section of this report. Cross sections were extracted from the DTM at points coincident with surveyed channel cross sections, which were spaced $800 \mathrm{ft}$ apart or less, with the exception of three cross sections at the upstream boundary of the unnamed tributary to Cardwell Branch, which did not have associated survey data. Stream stationing and path distances were calculated by GeoRAS using the stream centerline network and estimates of flow lines for the center of mass of overbank flow. Cross-sectional points between top-of-bank points that were derived from the topographic data were replaced by surveyed vertical and horizontal coordinates to improve the accuracy of channel geometry. 


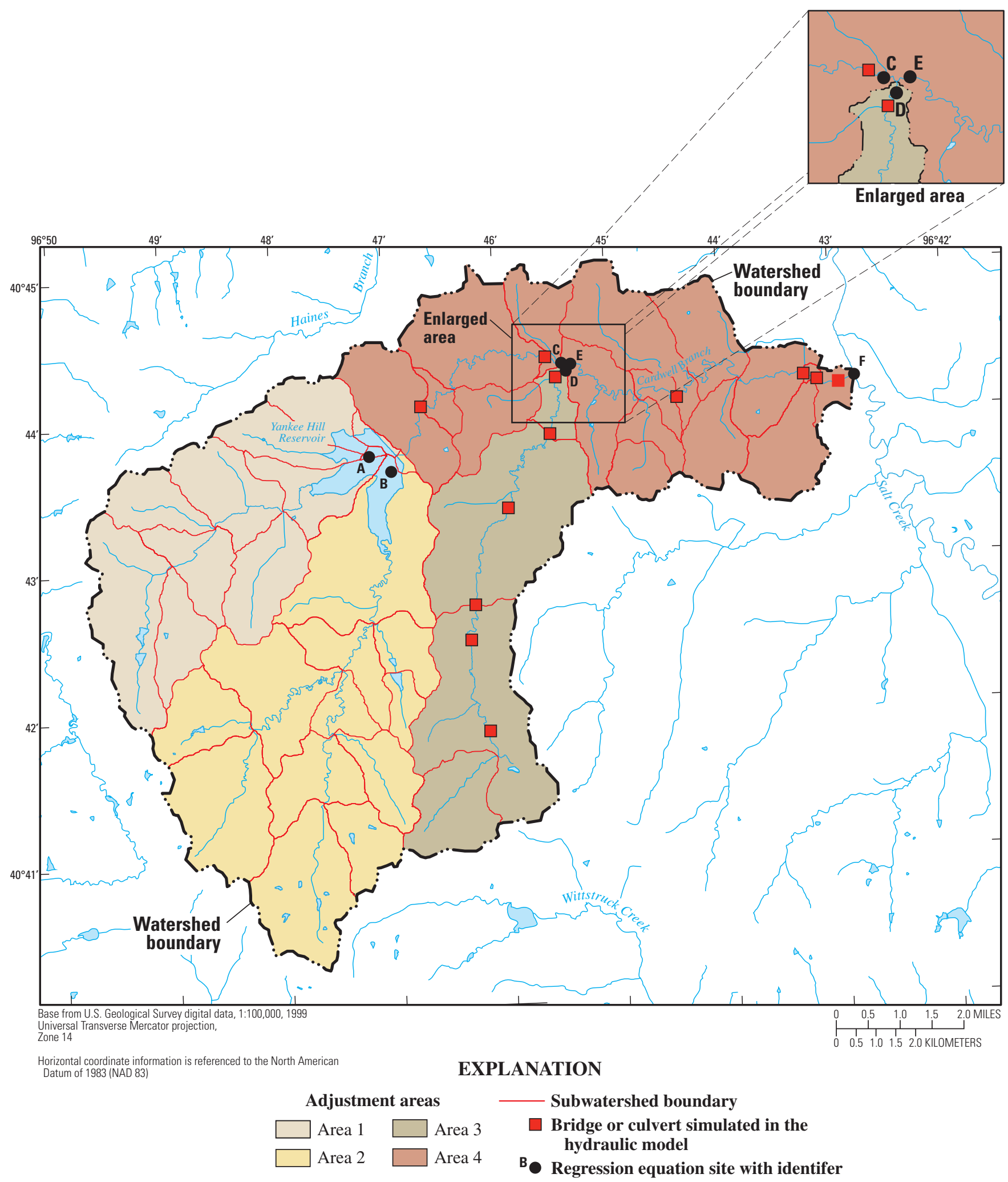

Figure 2. Locations where regional regression equations were computed and subwatershed groupings for which the hydrologic model was systematically adjusted, Cardwell Branch watershed. 
Table 2. Basin characteristics of the Cardwell Branch watershed, Nebraska, 2003-04.

[CDA, contributing drainage area; BS, basin slope; PLP, permeability of the least permeable layer.]

\begin{tabular}{lccc}
\hline $\begin{array}{c}\text { Site identifier } \\
\text { (fig. 2) }\end{array}$ & $\begin{array}{c}\text { CDA, in square } \\
\text { miles }\end{array}$ & $\begin{array}{c}\text { BS, in feet per } \\
\text { mile }\end{array}$ & $\begin{array}{c}\text { PLP, in } \\
\text { inches per } \\
\text { hour }\end{array}$ \\
\hline $\mathrm{A}$ & 3.5 & 85.1 & 0.13 \\
$\mathrm{~B}$ & 5.1 & 101.9 & .14 \\
$\mathrm{C}^{1}$ & 1.8 & 82.4 & .20 \\
$\mathrm{D}$ & 3.0 & 107.9 & .11 \\
$\mathrm{E}^{1}$ & 4.8 & 96.0 & .14 \\
$\mathrm{~F}^{1}$ & 7.7 & 81.0 & .17 \\
\hline
\end{tabular}

${ }^{1}$ The 8.6 square-mile area upstream from Yankee Hill Reservoir was excluded from the computation of basin characteristics for this site.

\section{Manning's Roughness Coefficients}

Manning's roughness coefficients ( $n$ values) for the main channel and overbank areas of the Cardwell Branch drainage network were determined from field observation using the Cowan method (Cowan, 1956; Arcement and Schneider, 1989). Photographs were taken at each cross section to document vegetation and stream conditions. Calculated $n$ values ranged from 0.028 to 0.056 for the main channel and from 0.050 to 0.160 for the flood plain.

\section{Bridges and Culverts}

WSEs at three bridges and nine culverts, including two culverts at private crossings, were simulated in HEC-RAS. Detailed field measurements, surveys of four cross sections positioned to describe the contraction and expansion reaches, and measurements of hydraulic properties were made at each of the bridge or culvert structures. Entrance-velocity headloss coefficients at culverts were selected from tables 6.3 and 6.4 of the HEC-RAS Hydraulic Reference Manual (U.S. Army Corps of Engineers, 2002). Contraction coefficients of 0.1 and expansion coefficients of 0.3 generally were used between cross sections to represent gradual variations between channel cross sections. At bridge and culvert structures, contraction and expansion coefficients were set to 0.3 and 0.5 , respectively, for the two cross sections immediately upstream and for the one cross section immediately downstream from the structures.

Left and right ineffective-flow areas were defined near bridges and culverts for low-flow and pressure-flow conditions in the HEC-RAS model. Stationing for ineffective flow areas near bridge and culvert structures was assigned using an assumed contraction ratio of 1:1 as long as that ineffective area did not infringe on the structure opening. The elevations specified for ineffective flows corresponded to the elevations where weir flow over the road would begin. Most of the simulated flows were subcritical except for one. The HECRAS model calculated that peak flows at or above the 20-percent frequency occur at critical depth at the crossing of Saltillo Road over the unnamed tributary (fig. 1).

\section{Estimating Peak Streamflow from High-Water Marks}

As a comparative measure for assessing the uncertainty of the $\mathrm{Q}_{p H M S}$ values, HWMs produced from recent (since 1996) runoff events in the Cardwell Branch watershed were used in conjunction with the HEC-RAS model to estimate the associated peak streamflow. There were several steps to this process. First, a WSE corresponding to the HWM was estimated from the topographic information available. Typically, the HWM was based on anecdotal evidence (such as, "the water reached the base of my fence post") and as a result, the WSE was assigned an arbitrary uncertainty of $\pm 1 \mathrm{ft}$. Next, the cross section nearest to the HWM was identified, and a theoretical WSE-discharge relation was computed by the HEC-RAS model. The WSE of the HWM was then compared to that relation to estimate $a Q_{p}$. However, because of the uncertainty associated with the WSE, this technique resulted in a range of $\mathrm{Q}_{p}$. Finally, the rainfall hyetograph that corresponded to the HWM was input into the HEC-HMS model to produce a $\mathrm{Q}_{p H M S}$ for comparison to the HWM-derived $\mathrm{Q}_{p}$. These rainfall data were obtained from rain-gage records (at 15-minute time increments) collected at the Salt Creek at Pioneers Boulevard gaging station, located approximately 5 mi northeast of the center of the watershed.

\section{Assessment of the Fluvial Geomorphology}

Fluvial geomorphology of the study area was assessed to characterize the stream channels and to identify both assets and hazardous areas potentially threatened by channel instability. Characterization of the stream-channel cross section (including the channel geometry, geomorphic classification, hydraulic geometry, and bank stability) was done at cross sections that were not adjacent to bridges or culverts. The cross sections then were grouped into reaches of similar geomorphic and hydrologic attributes, and summary reach characterizations were made. Finally, a profile of the thalweg elevation was developed, and comparisons to historical thalweg elevations were made to identify past streambed gradational changes.

In addition to the following described techniques, an attempt was made to assess the level of lateral channel migration by comparing aerial photography from the past 50 years. However, in most cases, the stream channel could not be clearly discerned from the adjacent riparian areas, and this analysis was inconclusive. 


\section{Stream-Channel Cross-Sectional Characterization}

Of the 134 cross sections, 103 were surveyed in natural channels (as opposed to those adjacent to bridges and culverts) in which channel geometry and geomorphic features were identified. These data were used in conjunction with historical, hydraulic, and geotechnical data to perform a variety of characterizations.

\section{Channel Geometry}

Using the topographic survey data collected in the field, some generalities were made for each cross section. The total bank heights and angles were calculated from the toe to the top of each bank. Bank width was the horizontal distance between the tops of each bank. Similarly, bankfull heights and widths were computed from the toe to the bankfull indicators when such indicators (described by Fitzpatrick and others, 1998) were observed in the field. Although this channelgeometry characterization is a simplification of that corresponding to the channel-forming discharge (Williams, 1978), it is assumed to be analogous.

The term bankfull, as used in this study, represents the depth of water associated with the channel-forming discharge, or bankfull discharge (Wolman and Miller, 1960; Knighton, 1998). Although the concept of bankfull and its corresponding channel indicators was originally conceived for undisturbed streams, most streams in eastern Nebraska (including Salt Creek, the receiving stream for Cardwell Branch) have become incised (Rus and others, 2003), and the total bank height is generally greater than the bankfull height. Nonetheless, characterizing bankfull conditions is needed for channel classification, and by identifying bankfull indicators in a disturbed system, inferences can be made as to the level of that disturbance. Several methods exist for determining the bankfull discharge (Williams, 1978), but the annual frequency of its peak discharge in an undisturbed channel is generally between 50- and 100-percent (Wolman and Miller, 1960; Leopold and others, 1964). Because the regional regression equations of Soenksen and others (1999) estimate discharges no less than the 50-percent frequency, the bankfull discharge of Cardwell Branch was assumed to correspond to a frequency of 50 percent for this study.

\section{Energy Associated with Bankfull Conditions}

Because of their effect on channel erodibility, average shear stress, average stream velocity, and average power were computed for each cross section under bankfull-discharge conditions. Average shear stress on the channel was computed as the product of the specific weight of water, the hydraulic radius, and the friction slope (Chow, 1959). Average velocity was simply the discharge divided by the cross-sectional area. The average power available in the channel was computed as the product of the average shear stress and the average velocity (Bagnold, 1966). Because of its relevance to channel-formation processes (Leopold and others, 1964), these energy terms were computed for bankfull discharge, which was estimated from the hydrologic model for a 50-percent frequency rainstorm. The HEC-RAS model performed all of these computations as part of the model simulation process.

\section{Channel Classification}

Stream-channel classification was done using three models: (1) the process-based channel evolution model of Simon (1989); (2) the form-based model of Rosgen (1994, 1996); and (3) the bank-stability index of Fitzpatrick and others (1998). Reach-specific classifications were done by determining the median values of the pertinent parameters from all of the cross sections in each reach. Stream classification provides a morphological description of a stream and is based on data obtained from field-determined indicators (Ward and Trimble, 2004). Some fluvial geomorphologists have concluded that it is inappropriate to use these classification systems beyond the purpose of characterization (Juracek and Fitzpatrick, 2003; Simon and others, 2005). Consequently, channel classifications done in this study are only intended to describe the condition of channels in the Cardwell Branch watershed.

\section{Streambank-Stability Analysis}

Because the region is characterized by loess soils (Soil Conservation Service, 1993) and has undergone channel incision and subsequent channel widening through masswasting streambank failures (Rus and others, 2003), streambank-stability assessments were performed at surveyed cross sections in the study area. The susceptibility to failures was characterized using a threshold safety factor of 1.3 (Coduto, 1999 , p. 529), in which the shear strength of the soil is 1.3 times that of the shear stress on it. Planar-failure assessments were made using the Culmann method (Lohnes and Handy, 1968; Spangler and Handy, 1973; Simon and others, 1999; Soenksen and others, 2003). Rotational-failure assessments were based on Bishop's simplified method of slices (Bishop, 1955) and used an implicit method developed for eastern Nebraska by Soenksen and others (2003). Two sets of failure-threshold curves were developed for each method by assuming: (1) ambient conditions and (2) saturated conditions. Both methods relied on soil properties to develop the curves, but these data were not collected as part of this study. Instead, soil-property data collected by Soenksen and others (2003) and rated as "fair" or better at five sites within $13 \mathrm{mi}$ of the watershed were used. Soil-property data for sites SC-1, SC-2, SC-3, SC-4, and SC-5 in Soenksen and others (2003) were averaged to obtain estimates of the streambank soil properties of the Cardwell Branch study area. These values were as follows: the average cohesion was $0.91 \mathrm{lb} / \mathrm{in}^{2}$; the average friction angle was 31.8 degrees; the average soil-unit weight under ambient conditions was $100 \mathrm{lb} / \mathrm{ft}^{3}$; and the average soil-unitweight under saturated conditions was $112 \mathrm{lb} / \mathrm{ft}^{3}$.

Measurements of bank angle and bank height of each cross section were plotted in relation to the failure-threshold 
curves. Banks plotting below the ambient threshold curve were categorized as stable; banks plotting between the ambient and saturated threshold curves were categorized as at risk; and banks plotting above the saturated threshold curve were categorized as unstable.

\section{Reach Characterization}

Stream reaches with similar fluvial attributes were differentiated as recommended by Shields and others (2003) to support the geomorphic assessment. The cross-sectional analyses were summarized for each reach, and meander geometry was characterized. Reach distinction was based primarily on a planform assessment that separated predominantly straightened reaches from meandering reaches and also took into account the presence of grade controls that may have geomorphically isolated one reach from another. A total of five reaches were delineated under these criteria (fig. 3).

The basic geometry of meanders (meander wavelength, $\lambda$; radius of curvature, $r_{c}$; and belt width, $B$ ) for each reach was characterized to compare to existing empirical relations with the bankfull width (Leopold and Wolman, 1960; Leopold and others, 1964; Williams, 1986). Meanders can theoretically be matched to sine-generated curves (Langbein and Leopold, 1966). In reality, meanders rarely follow these curves perfectly, owing to heterogeneous boundary materials and changing sediment loads (Vermont Agency of Natural Resources, 2004). To account for this variability, a set of five representative meanders were measured in each reach (except for reach 5, which had no well-defined meanders) (fig. 3) using hydrographic data obtained from the City of Lincoln that was delineated from aerial photography and topographic data having a 2-ft elevation contour interval (Cornerstone Mapping, Lincoln, Nebraska, unpub. data, 2003). The measured geometries for each meander then were averaged by reach.

\section{Thalweg Profile and Streambed Gradation}

The thalweg (or lowest point in the streambed) elevation for each cross section was paired with the corresponding stream distance from the watershed mouth (as determined by the hydraulic model) to compile a lateral streambed profile of the study area. Locations at which grade control of the streambed was observed at the time of surveying were identified on the profile (fig. 3). It should be noted that some structures (such as old road crossings) are providing incidental grade control and may only have a temporary effect if the structures are abandoned. Additionally, thalweg elevations measured at five bridges and culverts in 1978 were compared to those of recent surveys to determine the amount of streambed gradation that had taken place.

\section{Assessment of Stream Ecology}

The stream-ecology assessment included characterizations of stream chemistry, aquatic habitat, and aquatic biota. Water-quality data were grouped by streamflow type (base flow, runoff, or recession) and averaged. Aquatic-habitat data were summarized according to the frequency of occurrence in each distinctive geomorphic reach. The biotic data were more complex and required the computation of various metrics. Using the biological data collected in August 2003, several metrics were computed to characterize the aquatic community at the monitoring site.

\section{Fish Community Assessment}

The physical condition of individual fish specimens was used to understand the functionality of the aquatic system at the monitoring site. Growth rates, body composition, and body condition are all affected by numerous physical and biological factors in the aquatic ecosystem. A healthy, properly functioning ecosystem should support fish species at an empirically determined normal condition; specimens below the normal condition reveal problems in food or feeding conditions; and specimens above the normal condition may indicate a surplus in resources.

The relative weight $\left(W_{r}\right)$ (Anderson and Neumann, 1996) was used to describe the condition of each fish specimen. It was computed as the percentage ratio of the measured weight of a specimen compared to an expected weight predicted by a species-specific weight-length relation developed by Anderson and Neumann (1996) and expanded by Bister and others $(1999,2000) . W_{r}$ values between 95 and 105 percent are considered to be normally conditioned; $W_{r}$ values less than 95 percent are considered to be below normal; and values greater than 105 percent are considered to be above normal.

\section{Aquatic Invertebrate Metrics}

Aquatic invertebrates were collected using a variety of qualitative techniques designed to fully characterize the species richness of the system rather than the abundance of individuals within each species. Therefore, richness metrics according to taxa and functional feeding groups as defined in Barbour and others (1999) were used to assess the condition of the aquatic invertebrate community at the Cardwell Branch monitoring site (fig. 1).

\section{Algal Community Metrics}

Similar to the aquatic invertebrates, algal specimens were collected using qualitative techniques that targeted species richness rather than abundance. A series of metrics were computed from the richness data that characterized the algal community with regard to trophic state, saprobic state, and tolerances to $\mathrm{pH}$, salinity, nitrogen, dissolved oxygen, and general 


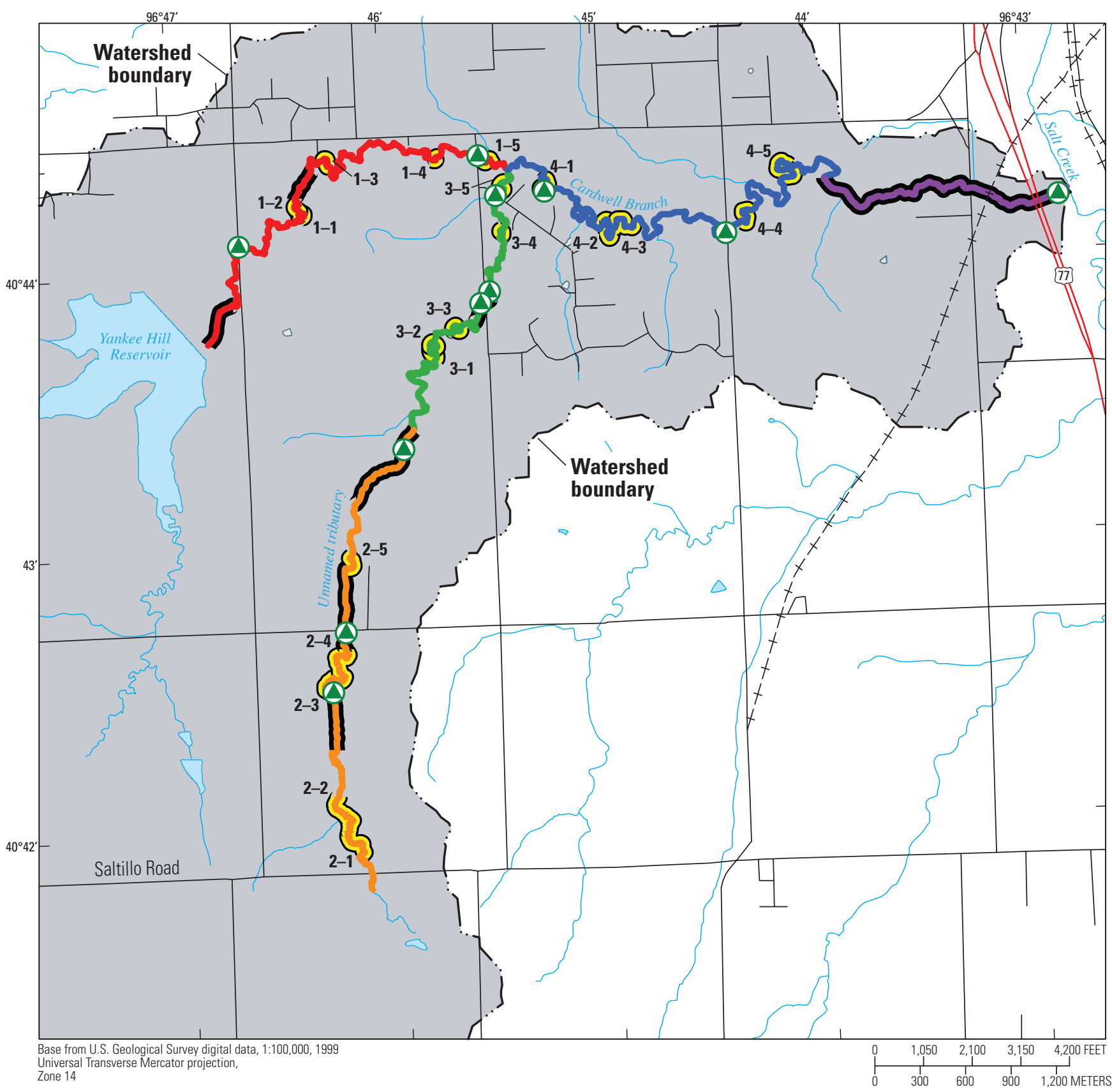

Horizontal coordinate information is referenced to the North American Datum of 1983 (NAD 83)

EXPLANATION

\begin{tabular}{|c|c|c|}
\hline $\begin{array}{l}\text { Geomorphic assessment reach } \\
\text { Reach } 1\end{array}$ & $2-5$ & $\begin{array}{l}\text { Representative meander and identifier } \\
\text { (overlain by reach line) }\end{array}$ \\
\hline Reach 2 & & Possibly straightened (overlain by reach line) \\
\hline Reach 4 & $\theta$ & Observed grade control \\
\hline
\end{tabular}

Figure 3. Geomorphically distinctive reaches. 
pollution. Tolerance-index values were obtained from Prescott (1962, 1968), Lowe (1974), Lange-Bertalot (1979), VanLandingham (1982), Bold and Wynne (1985), Bahls (1993), van Dam and others (1994), and Wehr and Sheath (2003).

\section{Results of Hydrologic Assessment}

Hydrologic and hydraulic models were developed for the Cardwell Branch study area, but considerable uncertainty is associated with the model simulations because no streamflow records are available for comparison purposes. Typically, greater variability is associated with hydrologic simulations than hydraulic simulations, so efforts were focused on comparing the hydrologic model to both regional regression equations and local HWMs. These comparative results were inconclusive and, at times, conflicting. Ultimately, two versions of the hydrologic model were developed in HEC-HMS, and peak flows from each were input to the hydraulic model to develop hydraulic simulations.

\section{Hydrologic Simulations}

Peak streamflows were essentially computed three different ways - using regional regression equations, using a HEC-HMS model based on the initial watershed parameter values (hereinafter referred to as the initial model), and using a HEC-HMS model in which the watershed parameter values were adjusted so that simulated $\mathrm{Q}_{p}$ would better compare with the regional regression equation results (the adjusted model).

\section{Regional Regression Equation Results}

Regional regression equations (Soenksen and others, 1999) were used to reasonably estimate 50-, 1-, and 0.2-percent-frequency $\mathrm{Q}_{p}$ at six sites (fig. 2) using basin characteristics computed for each site (table 2). The standard error of prediction (SEP) published with each equation (Soenksen and others, 1999) provides a statistically relevant measure of uncertainty for these estimates. Accordingly, a range of uncertainty for each $\mathrm{Q}_{p}$ estimate was computed at each site as the predicted value \pm 1 SEP (table 3 ).

\section{Initial Model Results}

$\mathrm{Q}_{p}$ simulated by the initial hydrologic model for the 50-, 1-, and 0.2-percent-frequency rainstorms at the six sites are given in table 3. The initial model estimated $\mathrm{Q}_{p}$ within 1 SEP of that estimated by the regression equations for the 50-percent-frequency rainstorm, but underestimated the $\mathrm{Q}_{p}$ for both the 1- and 0.2-percent-frequency rainstorms. This indicates that, when compared to the regression equations, the initial model may be well-suited for estimating $\mathrm{Q}_{p}$ for higher frequency rainstorms but may need adjustment to estimate $\mathrm{Q}_{p}$ during larger, rarer events. A summary of the parameter estimates is given in table 4 . The initial model is available in electronic form as part of the 2005 TSDN for the Cardwell Branch Watershed, Lancaster County, Nebraska (written commun., on file at the City of Lincoln Public Works Department, Watershed Management Division, and in review with the Federal Emergency Management Agency).

Table 3. Summary of peak streamflow estimates for the Cardwell Branch watershed, Nebraska, 2003-04.

[50-, 1-, and 0.2-percent frequency rainstorm magnitudes were 3.0, 6.68, and 8.2 inches, respectively, over a 24-hour period; Regression range, the range of peak flows estimated from the regional regression equations of Soenksen and others (1999), was computed as one standard error of prediction (SEP) less than the predicted value (Low) and one SEP greater than the predicted value (High); Initial model, peak flows estimated from the Hydraulic Engineering Center Hydrologic Modeling System (HEC-HMS) using the initial parameter estimates; Adj. model, peak flows estimated from HEC-HMS using the adjusted parameter estimates; NA, because of a localized reach where peak attenuation is expected, the regression equations may not be applicable at site F]

\begin{tabular}{|c|c|c|c|c|c|c|c|c|c|c|c|c|}
\hline \multirow{4}{*}{$\begin{array}{c}\text { Site } \\
\text { identi- } \\
\text { fier } \\
\text { (fig. 2) }\end{array}$} & \multicolumn{12}{|c|}{ Peak streamflow, in cubic feet per second } \\
\hline & \multicolumn{4}{|c|}{ 50-percent-frequency rainstorm } & \multicolumn{4}{|c|}{ 1-percent-frequency rainstorm } & \multicolumn{4}{|c|}{ 0.2-percent-frequency rainstorm } \\
\hline & \multicolumn{2}{|c|}{$\begin{array}{l}\text { Regression } \\
\text { range }^{1}\end{array}$} & \multirow{2}{*}{$\begin{array}{l}\text { Initial } \\
\text { model }\end{array}$} & \multirow{2}{*}{$\begin{array}{c}\text { Adj. } \\
\text { model }\end{array}$} & \multicolumn{2}{|c|}{$\begin{array}{l}\text { Regression } \\
\text { range }^{1}\end{array}$} & \multirow{2}{*}{$\begin{array}{l}\text { Initial } \\
\text { model }\end{array}$} & \multirow{2}{*}{$\begin{array}{c}\text { Adj. } \\
\text { model }\end{array}$} & \multicolumn{2}{|c|}{$\begin{array}{l}\text { Regression } \\
\text { range }^{1}\end{array}$} & \multirow{2}{*}{$\begin{array}{l}\text { Initial } \\
\text { model }\end{array}$} & \multirow{2}{*}{$\begin{array}{c}\text { Adj. } \\
\text { model }\end{array}$} \\
\hline & Low & High & & & Low & High & & & Low & High & & \\
\hline A & 340 & 879 & 718 & 1,290 & 3,980 & 7,580 & 2,580 & 4,210 & 5,920 & 12,500 & 3,670 & 5,800 \\
\hline $\mathrm{B}$ & 460 & 1,190 & 953 & 1,580 & 4,940 & 9,410 & 3,400 & 5,350 & 7,210 & 15,300 & 4,780 & 7,570 \\
\hline $\mathrm{C}$ & 233 & 603 & 460 & 463 & 2,440 & 4,650 & 1,370 & 1,910 & 3,720 & 7,890 & 1,730 & 2,550 \\
\hline D & 393 & 1,010 & 523 & 844 & 4,320 & 8,230 & 1,780 & 4,090 & 6,260 & 13,300 & 2,380 & 5,640 \\
\hline $\mathrm{E}$ & 469 & 1,210 & 967 & 1,250 & 4,770 & 9,080 & 3,150 & 5,970 & 6,940 & 14,700 & 4,050 & 8,130 \\
\hline F & NA & NA & 840 & 809 & NA & NA & 2,410 & 3,510 & NA & NA & 3,210 & 4,710 \\
\hline
\end{tabular}

${ }^{1}$ Whereas the hydrologic model estimates the peak flow associated with a rainstorm of given frequency, the regional regression equations directly estimate the peak flow of a given frequency. 
Table 4. Summary of parameter estimates used in the initial hydrologic model of the Cardwell Branch watershed, Nebraska, $2003-04$.

[mi², square miles; Max., maximum; Min., minimum]

\begin{tabular}{|c|c|c|c|c|c|c|c|c|c|c|}
\hline \multirow{2}{*}{$\begin{array}{l}\text { Adjust- } \\
\text { ment } \\
\text { area } \\
\text { (fig. 2) }\end{array}$} & \multicolumn{2}{|c|}{ Subwatershed area $\left(\mathrm{mi}^{2}\right)$} & \multicolumn{2}{|c|}{ Curve number } & \multicolumn{2}{|c|}{$\begin{array}{c}\text { Unit hydrograph } \\
\text { lag time } \\
\text { (minutes) }\end{array}$} & \multicolumn{2}{|c|}{$\begin{array}{l}\text { Manning's roughness } \\
\text { coefficient, flood plain }\end{array}$} & \multicolumn{2}{|c|}{$\begin{array}{l}\text { Manning's roughness } \\
\text { coefficient, channel }\end{array}$} \\
\hline & Max. & Min. & Max. & Min. & Max. & Min. & Max. & Min. & Max. & Min. \\
\hline${ }^{1} 1$ & 0.702 & 0.275 & 87.1 & 80.4 & 75 & 19 & 0.083 & 0.061 & 0.045 & 0.045 \\
\hline 2 & 1.04 & .018 & 83.7 & 78 & 41 & 5 & .083 & .061 & .045 & .045 \\
\hline
\end{tabular}

${ }^{1}$ Two small subwatersheds contained entirely within the open water of Yankee Hill Reservoir are not included in the summary statistics.

\section{Adjusted Model Results}

The model parameters were systematically adjusted so as to maintain comparability to the 50-percent-frequency $\mathrm{Q}_{p}$ of the regression equations, while improving the comparability to the 1- and 0.2-percent-frequency $\mathrm{Q}_{p}$. Typically, adjustments of a parameter would affect $\mathrm{Q}_{p}$ for all three frequencies. To overcome this artifact of the model, substantial positive adjustment of the channel roughness coefficient occurred and was paired with similarly large negative adjustment of the flood-plain roughness coefficient (table 5). This produced roughness values outside of the typical range (for example, one reach was assigned a channel roughness coefficient of 0.249). When compared to the reasonable ranges of $\mathrm{Q}_{p}$ estimated by the regression equations, these adjustments improved the ability of the model to estimate $\mathrm{Q}_{p}$ at the 1- and 0.2-percent frequency at all of the comparison sites but reduced its ability to estimate $\mathrm{Q}_{p}$ at the 50-percent frequency at three of the sites (table 3).

\section{Comparison to Local High-Water Marks}

The regional regression equations are based on observed flow data from nearby streams that are assumed to

Table 5. Systematic adjustments made to selected parameters of the initial hydrologic model for the adjusted hydrologic model of the Cardwell Branch watershed, 2003-04

\begin{tabular}{|c|c|c|c|c|}
\hline \multirow{2}{*}{$\begin{array}{l}\text { Adjustment } \\
\text { area (fig. 2) }\end{array}$} & \multirow{2}{*}{$\begin{array}{c}\text { Percentage } \\
\text { of initial- } \\
\text { curve } \\
\text { number }\end{array}$} & \multirow{2}{*}{$\begin{array}{l}\text { Percent- } \\
\text { age of } \\
\text { initial unit } \\
\text { hydrograph } \\
\text { lag time }\end{array}$} & \multicolumn{2}{|c|}{$\begin{array}{c}\text { Percentage of initial } \\
\text { Manning's roughness } \\
\text { coefficient }\end{array}$} \\
\hline & & & Channel & $\begin{array}{l}\text { Flood } \\
\text { plain }\end{array}$ \\
\hline 1 & 105 & 80 & 150 & 50 \\
\hline 2 & 105 & 80 & 150 & 50 \\
\hline 13 & 105 & 80 & 200 & 25 \\
\hline 4 & 105 & 80 & 150 & 50 \\
\hline
\end{tabular}

${ }^{1}$ Channel-routing geometry also was modified in this area by adding 2 feet of depth and 10 feet of width to the channel. be analogous to Cardwell Branch, whereas HWMs measured within the watershed can provide insight into the hydrologic conditions specific to Cardwell Branch. Anecdotal evidence was relied on because well-documented HWMs that included an explicit HWM elevation and corresponding rainfall hyetograph were not available.

A series of anecdotal HWMs, for which the elevation could only be estimated to within $1 \mathrm{ft}$, were offered at several of the bridges and culverts. The WSE-discharge relation can be highly dynamic in the presence of a bridge or culvert, however, and the corresponding estimates of $\mathrm{Q}_{p}$ were deemed too uncertain to compare to the hydrologic model results.

Two anecdotal HWMs (as before, probably only accurate to within $1 \mathrm{ft}$ ) were offered away from any bridges or culverts. The first corresponded to a rainstorm on July 20, 1996 , from which approximately 6.5 in. ( \pm 0.5 in.) of rainfall were measured by a nearby landowner near the confluence of Cardwell Branch and the unnamed tributary. An estimated hyetograph of this storm was developed by relating the storm total to hourly National Weather Service precipitation data measured at the Lincoln Municipal Airport. A photograph of the runoff produced by this storm (fig. 4) was used to estimate an HWM elevation (to an assumed precision of $\pm 1 \mathrm{ft}$ ), and a corresponding $\mathrm{Q}_{p}$ between 870 and 1,680 ft $3 / \mathrm{s}$ was estimated from the hydraulic model. When this rainfall hyetograph was simulated with the hydrologic model for comparison, the initial model produced a $\mathrm{Q}_{p}$ of approximately $1,280 \mathrm{ft}^{3} / \mathrm{s}$ near the HWM; whereas, the adjusted model produced a $\mathrm{Q}_{p}$ of approximately $2,680 \mathrm{ft}^{3} / \mathrm{s}$.

The second HWM elevation was derived from anecdotal evidence provided by a local landowner and corresponded to a 1.92-in. rainstorm (as measured at the Southwest 56th Street bridge over Haines Branch) on June 9-10, 2003 (U.S. Geological Survey, 2006). A corresponding $Q_{p}$ between 600 and $1,300 \mathrm{ft}^{3} / \mathrm{s}$ was estimated from the hydraulic model, which compared to a $\mathrm{Q}_{p}$ of approximately $600 \mathrm{ft}^{3} / \mathrm{s}$ produced by the initial hydrologic model and a $\mathrm{Q}_{p}$ of $720 \mathrm{ft}^{3} / \mathrm{s}$ produced by the adjusted hydrologic model.

Comparing the simulated $\mathrm{Q}_{p}$ with those derived from the HWMs, the initial and adjusted hydrologic models both produced reasonable $\mathrm{Q}_{p}$ estimates corresponding to the 1.92-in. 


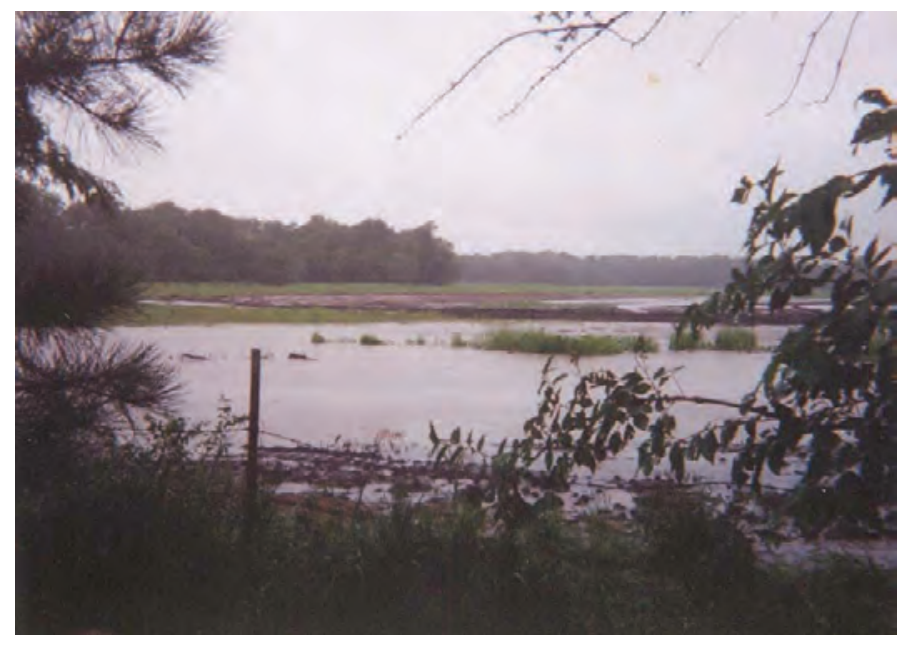

Figure 4. Photograph of runoff in the Cardwell Branch watershed following an estimated 6.5-inch rainfall on July 20, 1996 (photograph taken by Dave Sands, landowner in the Cardwell Branch watershed).

rainstorm of June 9-10, 2003. However, only the initial model produced $\mathrm{Q}_{p}$ values within the expected range for the much larger rainstorm of July 20, 1996. These HWM comparisons indicate that the initial hydrologic model may better estimate $\mathrm{Q}_{p}$ in the Cardwell Branch watershed. It should be noted, though, that because both HWMs were anecdotal, the uncertainty in these comparisons should be considered fairly high, and the unresolved question remains, "Which version of the model is correct?" This also may reveal problems with the assumption that rainfall of a given frequency produces $\mathrm{Q}_{p}$ of the same frequency. As a result, both versions of the model are retained for use in the hydraulic simulations. A more accurate comparison might be possible in the future if well-documented HWMs or measured streamflows become available.

\section{Hydraulic Simulations}

Using the results of the hydrologic simulations in conjunction with the hydraulic characterizations of the river system, a hydraulic model was developed. After the initial hydraulic simulations (based on the initial hydrologic model simulations of 1-percent-frequency $\mathrm{Q}_{p}$ ), warning messages presented by the program were evaluated for relevance, and the results were assessed for accuracy. Warning messages and other scrutinizing often were related to: (1) critical depth water-surface calculations; (2) conveyance ratios less than 0.7 or greater than 1.4 ; (3) imbalance of the energy equation; (4) WSE differences greater than $1 \mathrm{ft}$ between adjacent cross sections; (5) ineffective flow areas, especially near bridges or culverts; and (6) usage of ascribed levees to confine flows to realistic flow paths. This process is documented in further detail in the 2005 TSDN for the Cardwell Branch watershed, Lancaster County, Nebraska, which is on file at the City of Lincoln and in review with the Federal Emergency Management Agency.

Once developed, the hydraulic model was used to compare WSEs associated with the initial hydrologic model and the adjusted hydrologic model (table 6). As expected, $\mathrm{Q}_{p}$ from the adjusted hydrologic model generally produced higher WSEs than the initial model. Once again, without measured HWMs or streamflow data, it is inconclusive which of these two hydrologic model versions is more accurate.

\section{Results of Fluvial-Geomorphic Assessment}

On the basis of evidence collected for this study, Cardwell Branch and its unnamed tributary appear to be undergoing incision, which is somewhat tempered by the presence of 11 grade controls and woody vegetation along the channel profile. Channel classification systems indicated that all of the reaches within the study area were incising and widening, with three channel forms commonly occurring. Meander analysis was inconclusive for the study area, possibly because of the effects of past straightening.

Table 6. Summary of differences in water-surface elevation estimates derived from the two hydrologic models of the Cardwell Branch watershed, 2003-04.

[WSE, water-surface elevation.]

WSE ${ }^{1}$ difference for peak discharges corresponding to the two hydrologic models for the indicated

Water-surface elevations (feet) storms

50-percent-frequency rainstorm 1-percent-frequency rainstorm $\quad$ 0.2-percent-frequency rainstorm

\begin{tabular}{lccc}
\hline Maximum & 2.9 & 5.6 & 10.1 \\
Average & 0.2 & 1.1 & 1.4 \\
Minimum & -1.3 & 0.1 & -0.3 \\
\hline
\end{tabular}

${ }^{1}$ Differences were computed (using the hydraulic model) as the WSE corresponding to the adjusted hydrologic model minus the WSE corresponding to the initial hydrologic model. 


\section{Cross-Sectional Characterization}

Cross-sectional surveys and field assessments done between November 2003 and March 2004 produced evidence of widespread imbalances of varying degree in the dynamic nature of the streams, and historical data indicate that as much as $2.3 \mathrm{ft}$ of incision have occurred at points in the lower reaches of Cardwell Branch over the past 25 years. At each of 103 surveyed cross sections, the channel geometry (Appendix 1), field assessments (Appendix 2), channel classifications (Appendix 3), and streambank stability were characterized.

\section{Channel Geometry}

Comparisons of channel depths with bankfull depths $\left(\mathrm{D}_{b f}\right)$ indicate that most of the streams in the study area are incised. $\mathrm{D}_{b f}$ in a stable stream will, on average, match the total-channel depths $\left(\mathrm{D}_{\text {chan }}\right)$ (shown as a "1:1 line" in fig. $5 A$ ), whereas $\mathrm{D}_{b f}$ will be less than $\mathrm{D}_{\text {chan }}$ in an unstable, incising stream. Eightythree percent of the surveyed cross sections in the study area had $\mathrm{D}_{b f} s$ that were less than $\mathrm{D}_{\text {chan }}$ (fig. $5 A$ ).

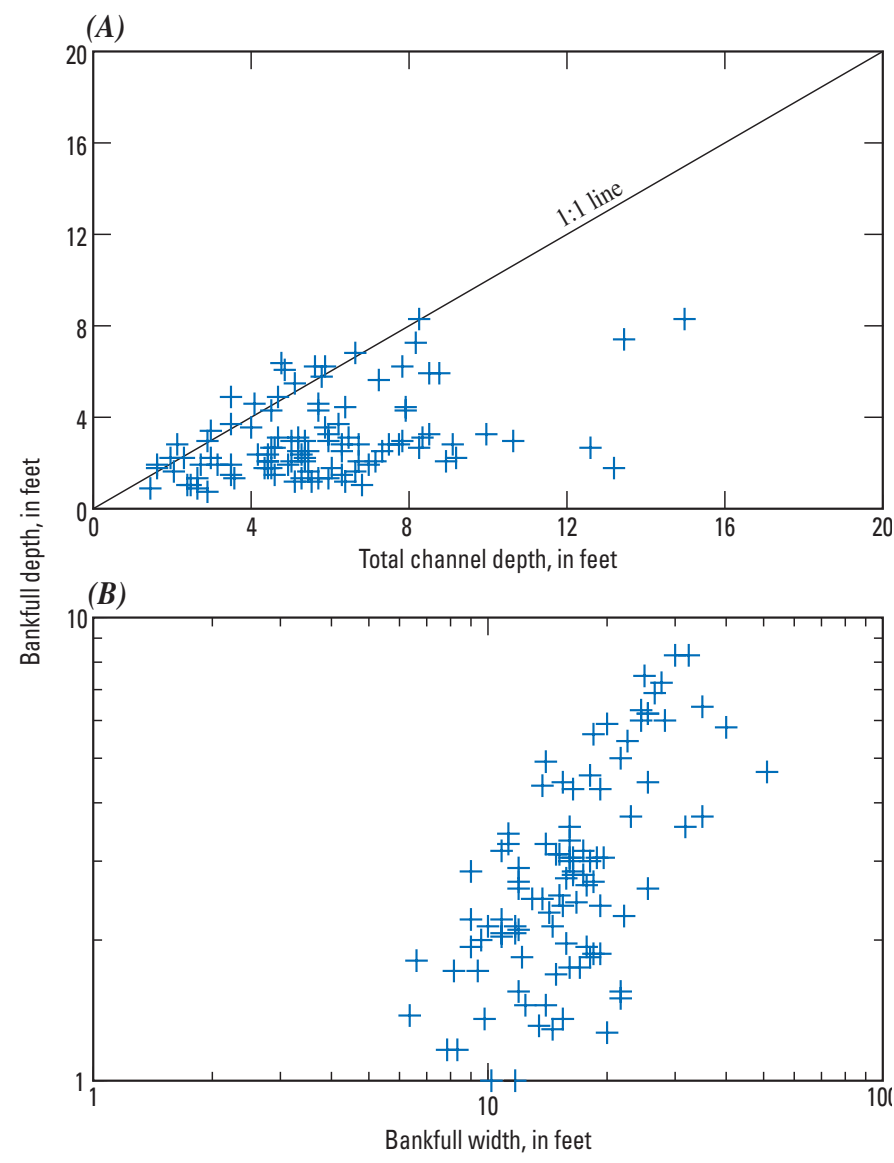

Figure 5. Channel geometries observed in the Cardwell Branch watershed in which bankfull geometries were obtained from the field indicators.
Further evidence of incision is provided by comparing to the survey data collected in 1978 for the original Flood Insurance Study for Lancaster County (Federal Emergency Management Agency, 2001). These two survey data sets indicate between 1.3 and $2.3 \mathrm{ft}$ of incision (table 7) for Cardwell Branch since 1978 between the Highway 77 bridge and the Southwest 12th Street culvert (which was a bridge in 1978).

A reasonable correlation of bankfull width $\left(\mathrm{W}_{b f}\right)$ to $\mathrm{D}_{b f}$ was observed (fig. $5 B$ ). The mean value of $\mathrm{W}_{b f}$ was $17 \mathrm{ft}$, and the mean ratio of $\mathrm{W}_{b f}$ to $\mathrm{D}_{b f}$ was 6.5 , which both indicate mean streambed silt-clay percentages of 20 percent or more when compared to similar relations given in Schumm (1960). An attempt was made to develop a relation of $\mathrm{W}_{b f}$ to the 50percent-frequency $\mathrm{Q}_{p}$ following the approach of Osterkamp and Hedman (1982), but the analysis was inconclusive.

Visual field assessments also indicated that the dominant streambed material was silt or finer at nearly every cross section. Deposition of sand was not observed, and only in the lower reaches of Cardwell Branch were cobble-sized materials intermittently observed. These cobbles were not widespread and are believed to be the result of either artificial additions to the stream or as the result of local streambed incision into bedrock materials. The majority of sediments in the study area, are composed of silt-sized (less than 0.0024 in. in diameter) or finer materials.

The types of flow in the study area did not vary between riffles, runs, and pools. This was not unexpected as these are characteristics of perennial channels having sandy streambed (or coarser) materials (Leopold and others, 1964). Channels containing water at the time of assessment typically had backwater areas created by beaver dams alternating with short runs of flowing water. The flow type was estimated in dry channels, but considerable uncertainty is associated with those estimates.

\section{Streambank-Stability Assessments}

Although streambank-stability assessments suggest that the system generally is resistant to streambank failures through geotechnically unstable mass-wasting processes, several of these failures have occurred recently enough to be observed at the time of survey. Using the soil properties estimated from Soenksen and others (2003), streambank-failure envelope curves were developed for various combinations of streambank height and streambank angle. With regard to the susceptibility to planar failures (fig. 6A), 96 percent of the cross sections were categorized as being stable with a safety factor of 1.3. The susceptibility to rotational failures (fig. 6B) also was low, with 96 percent of the cross sections categorized as being stable at a safety factor of 1.3. These stability assessments rely on the assumed soil property data as well as the assumption of spatial homogeneity of those properties in the study area. It is likely that some areas of the study area may have less geotechnically stable materials than others, and those areas may be more likely to have streambank failures. This point is further illustrated by the fact that evidence of 
Table 7. Comparison of thalweg elevations between 1978 and 2003-04 in Cardwell Branch, Nebraska.

[NAVD 88, North American Vertical Datum of 1988; NA, because of a grade-control structure present at the Southwest 27th Street crossing, the thalweg elevation is not applicable for comparison]

\section{Structure}

(feet above elevation

2003-04 thalweg

elevation

(feet above NAVD 88)

Highway 77 crossing over Cardwell Branch

Railroad crossing over Cardwell Branch

$1,158.4$

$1,161.0$

$1,161.9$

$1,177.7$

$1,192.8$

$1,156.1$

$1,158.8$

$1,160.6$

$1,175.5$

NA
Southwest 12th Street crossing over Cardwell Branch

$1,192.8$

Change in thalweg elevation (feet)

${ }^{1}$ Taken from land-survey data collected for the Lancaster County Flood Insurance Study (Federal Emergency Management Agency, 2001).

$-2.3$

$-2.2$

$-1.3$

$-2.2$

NA

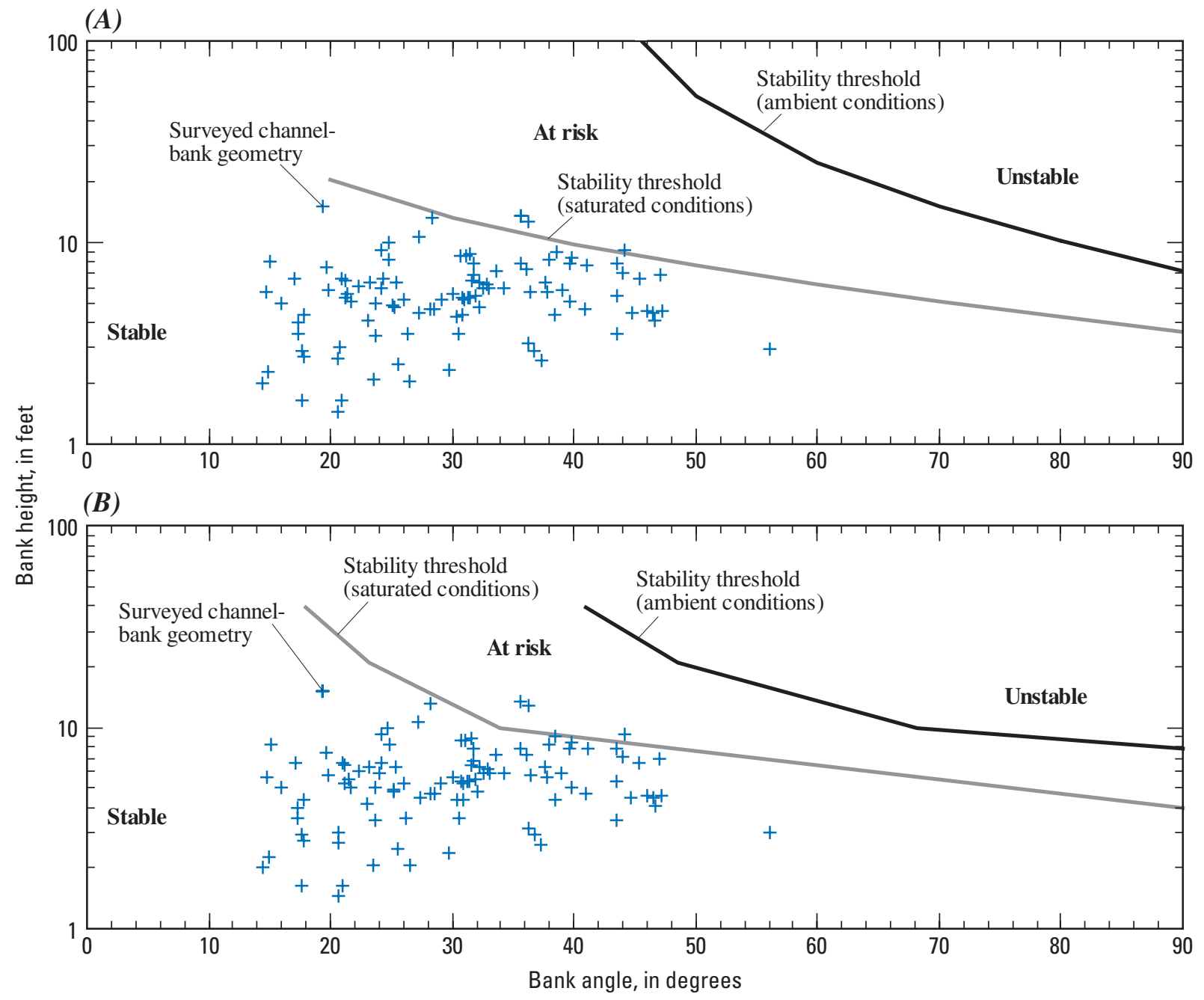

Figure 6. Streambank geometry and bank-failure envelope curves for the Cardwell Branch study area showing threshold values for $(A)$ planar failures and $(B)$ rotational failures. 
streambank failures was observed in the field at 33 percent of the surveyed cross sections.

\section{Reach Characterization}

Cross-sectional characterizations were the basis for delineating five distinctive reaches to summarize the geomorphic assessment (fig. 3). Additionally, the meander geometry was characterized and a thalweg profile was developed for each reach.

\section{Summary of Cross-Sectional Characterizations}

Median channel geometries in the study area are listed in table 8 . The only reach lacking any obvious channel straightening, reach 4, had the highest sinuosity and the lowest reach slope. This is consistent with historical reports from other streams in southeastern Nebraska in which the sinuosity of the original channel varied between 2 and 4 but straightening reduced it to a value near 1 (Moore, 1915). It is reasonable to assume that the sinuosity and slope observed at reach 4 may be nearest to the natural stream dynamic equilibrium for the Cardwell Branch watershed.

Both reaches of the unnamed tributary (reaches 2 and 3 ) are experiencing higher shear stresses applied to the channel during bankfull streamflow than the reaches of Cardwell Branch (table 9). This is in part the result of higher reach slopes in the tributary (table 8) and indicates that the unnamed tributary may be more prone to channel erosion than Cardwell Branch in the study area.

Assessments done in the field at the time of surveying are summarized in table 10. Although mostly qualitative, the field assessments indicate the predominance of silty materials in the stream channel as well as the relative differences between reaches. Woody, riparian vegetation has been recognized for its stabilizing effect on streambanks (Simon and Collison, 2002) and was observed to be doing as much in all reaches. Several log jams were observed throughout the study area that may serve as quasi-grade controls during runoff of higher frequency (and lower magnitude). Similarly, in reaches 4 and 5 many beaver dams were observed where water was flowing. Beaver dams typically occur on first- through fourth-order streams and are responsible for decreasing current velocity,

Table 8. Summary of channel geometry in the Cardwell Branch study area, Nebraska.

\begin{tabular}{|c|c|c|c|c|c|c|c|c|}
\hline Reach (fig. 3) & $\begin{array}{l}\text { Number of } \\
\text { surveyed } \\
\text { cross } \\
\text { sections }\end{array}$ & $\begin{array}{c}\text { Median } \\
\text { channel } \\
\text { depth (feet) }\end{array}$ & $\begin{array}{c}\text { Median } \\
\text { bank angle } \\
\text { (degrees) }\end{array}$ & $\begin{array}{c}\text { Median } \\
\text { channel } \\
\text { width (feet) }\end{array}$ & $\begin{array}{c}\text { Median } \\
\text { bankfull } \\
\text { depth (feet) }\end{array}$ & $\begin{array}{c}\text { Median } \\
\text { bankfull } \\
\text { width (feet) }\end{array}$ & $\begin{array}{l}\text { Reach slope } \\
\text { (foot per foot) }\end{array}$ & $\begin{array}{c}\text { Reach } \\
\text { sinuosity }\end{array}$ \\
\hline 1 & 28 & 5.3 & 25 & 38 & 2.8 & 16 & 0.0019 & 1.50 \\
\hline 2 & 18 & 2.9 & 23 & 19 & 1.5 & 12 & .0052 & 1.31 \\
\hline 3 & 22 & 4.5 & 32 & 22 & 2.3 & 12 & .0033 & 1.48 \\
\hline 5 & 10 & 9.3 & 33 & 48 & 3.0 & 18 & .0028 & 1.21 \\
\hline
\end{tabular}

${ }^{1}$ Cross sections adjacent to bridges or culverts were excluded.

Table 9. Summary of energy terms related to bankfull flows in the Cardwell Branch study area, Nebraska.

[All values given are medians of the cross sections within each reach]

\begin{tabular}{|c|c|c|c|c|c|c|}
\hline \multirow[b]{2}{*}{$\begin{array}{l}\text { Reach } \\
\text { (fig. 3) }\end{array}$} & \multicolumn{3}{|c|}{ Initial hydrologic model' } & \multicolumn{3}{|c|}{ Adjusted hydrologic model ${ }^{2}$} \\
\hline & $\begin{array}{c}\text { Power } \\
\text { (pounds per foot } \\
\text { per second) }\end{array}$ & $\begin{array}{l}\text { Shear stress } \\
\text { (pounds per } \\
\text { square foot) }\end{array}$ & $\begin{array}{l}\text { Stream velocity } \\
\text { (feet per second) }\end{array}$ & $\begin{array}{c}\text { Power } \\
\text { (pounds per } \\
\text { square foot) }\end{array}$ & $\begin{array}{l}\text { Shear stress } \\
\text { (pounds per } \\
\text { square foot) }\end{array}$ & $\begin{array}{l}\text { Stream velocity } \\
\text { (feet per second) }\end{array}$ \\
\hline 1 & 0.4 & 0.2 & 2.1 & 0.5 & 0.2 & 2.1 \\
\hline 2 & 3.4 & .7 & 4.4 & 3.6 & .8 & 4.6 \\
\hline 3 & 2.4 & 6 & 4.0 & 3.7 & .8 & 4.5 \\
\hline 4 & 1.4 & .3 & 3.9 & 1.3 & .3 & 3.9 \\
\hline 5 & .7 & .2 & 3.6 & .8 & .2 & 3.8 \\
\hline
\end{tabular}

${ }^{1}$ Computed from the hydraulic model and corresponding to the 50-percent-frequency streamflows estimated by the initial hydrologic model (model parameters were unadjusted).

${ }^{2}$ Computed from the hydraulic model and corresponding to the 50-percent-frequency streamflows estimated by the adjusted hydrologic model (model parameters were adjusted so that the output was similar to regional regression equations). 
Table 10. Summary of field assessments in the Cardwell Branch study area, Nebraska.

\begin{tabular}{|c|c|c|c|c|c|c|c|}
\hline $\begin{array}{l}\text { Reach } \\
\text { (fig. 3) }\end{array}$ & $\begin{array}{c}\text { Percentage of } \\
\text { cross sections } \\
\text { with stabilizing } \\
\text { vegetation }\end{array}$ & $\begin{array}{c}\text { Percentage of } \\
\text { cross sections } \\
\text { with log jams } \\
\text { nearby }\end{array}$ & $\begin{array}{c}\text { Dominant } \\
\text { streambed } \\
\text { material }\end{array}$ & $\begin{array}{c}\text { Dominant } \\
\text { streambank } \\
\text { material }\end{array}$ & $\begin{array}{l}\text { Average veg- } \\
\text { etative cover } \\
\text { (percent) }\end{array}$ & $\begin{array}{l}\text { Percentage of } \\
\text { cross sections } \\
\text { with observed } \\
\text { streambank } \\
\text { failures }\end{array}$ & $\begin{array}{c}\text { Percentage of } \\
\text { cross sections } \\
\text { with observed } \\
\text { toe erosion }\end{array}$ \\
\hline 1 & 46 & 32 & Silt & Silt & 37 & 14 & 39 \\
\hline 2 & 28 & 6 & Silt & Silt & 44 & 22 & 17 \\
\hline 4 & 40 & 44 & Silt & Silt & 30 & 36 & 56 \\
\hline 5 & 20 & 50 & Silt & Silt & 48 & 40 & 60 \\
\hline
\end{tabular}

giving the channel gradient a stair-step profile, and retaining sediment (Naiman and others, 1988) that may assist in returning incised streams to predisturbed conditions by causing aggradation (McCullough and others, 2004).

The process-based classification systems of Simon (1989) and Fitzpatrick and others (1998) both indicated that all reaches within the study area were unstable, incising, and widening (table 11). The form-based classification system of Rosgen (1994) indicated two commonly occurring stream types (table 11). Reach 1 was classified as stream type E6 (Rosgen, 1996). Such channels typically are hydraulically efficient with low width-depth ratios, low to moderate sinuosity, and gentle to moderately steep slopes. The other reaches were classified as stream type B6c (Rosgen, 1996). These channels typically are incised with low width-depth ratios maintained by riparian vegetation, low bedload transport, and high washload transport.

\section{Meander Geometry}

Five representative meanders in each reach except reach 5 were used to characterize the typical meander geometry (fig. 3). Reach 5 had no well-defined meanders because of extensive straightening. The basic geometry of meanders in reaches 1-5 was measured and summarized (table 12, Appen$\operatorname{dix} 4)$.

The relation of meander wavelength to $\mathrm{W}_{b f}$ in the study area did not agree well with the empirical relation developed by Leopold and Wolman (1960) (fig. 7A), with a generally high bias. This may indicate a possible overestimation of meander wavelength or underestimation of bankfull width. Williams (1986) points out that the most significant source of error in meander geometry analysis is the delineation of the meanders, and this is a likely source of error here. There was a better relation of the radius of curvature to $\mathrm{W}_{b f}$ in the study area when compared to the typical relations noted by Leopold and others (1964) (fig. 7B). The lack of strong correlation of the meanders in the study area to either empirical relation may be because the relations were developed for natural streams in dynamic equilibrium, whereas the effects of past straightening have probably disturbed the equilibrium of streams in the Cardwell Branch watershed. Variability in the meander geometry (table 12, fig. 7) indicates that the error associated with meander delineation coupled with the state of disturbance

Table 11. Summary of channel classifications in the Cardwell Branch study area, Nebraska.

[W:D, width-to-depth ratio associated with the bankfull discharge; E6 channels typically are hydraulically efficient with low width-depth ratios, low to moderate sinuosity, and gentle to moderately steep slopes; B6c channels typically are incised with low width-depth ratios maintained by riparian vegetation, low bedload transport, and high washload transport]

\begin{tabular}{|c|c|c|c|c|c|c|}
\hline \multirow[b]{2}{*}{$\begin{array}{l}\text { Reach } \\
\text { (fig. 3) }\end{array}$} & \multirow[b]{2}{*}{$\begin{array}{c}\text { Median stage of } \\
\text { channel evolu- } \\
\text { tion }^{1}\end{array}$} & \multicolumn{2}{|c|}{ Bank stability index ${ }^{2}$} & \multicolumn{3}{|c|}{ Form-based classification ${ }^{3}$} \\
\hline & & $\begin{array}{l}\text { Median index } \\
\text { value }\end{array}$ & $\begin{array}{l}\text { Stability class } \\
\text { of the median } \\
\text { index value }\end{array}$ & $\begin{array}{l}\text { Median entrench- } \\
\text { ment ratio }\end{array}$ & Median W:D & $\begin{array}{c}\text { Stream type } \\
\text { of the median } \\
\text { channel }\end{array}$ \\
\hline 1 & 4 & 11.0 & Unstable & 2.2 & 5.8 & E6 \\
\hline 2 & 4 & 11.0 & Unstable & 1.7 & 8.8 & $\mathrm{~B} 6 \mathrm{c}$ \\
\hline 3 & 4 & 12.5 & Unstable & 1.8 & 4.6 & $\mathrm{~B} 6 \mathrm{c}$ \\
\hline 4 & 4 & 13.0 & Unstable & 1.6 & 5.6 & B6c \\
\hline 5 & 4 & 13.0 & Unstable & 1.8 & 5.1 & $\mathrm{~B} 6 \mathrm{c}$ \\
\hline
\end{tabular}

\footnotetext{
${ }^{1}$ From Simon (1989).

${ }^{2}$ From Fitzpatrick and others (1998).

${ }^{3}$ From Rosgen (1994).
} 
Table 12. Summary of meander geometry in the Cardwell Branch study area, Nebraska.

[NA, not applicable as no meanders were observed in this reach]

\begin{tabular}{|c|c|c|c|c|}
\hline $\begin{array}{l}\text { Reach } \\
\text { (fig. 3) }\end{array}$ & $\begin{array}{l}\text { Percentage } \\
\text { of reach } \\
\text { length } \\
\text { determined } \\
\text { to be } \\
\text { artificially } \\
\text { straight- } \\
\text { ened }\end{array}$ & $\begin{array}{c}\text { Average } \\
\text { meander } \\
\text { wavelength } \\
\text { (feet) }\end{array}$ & $\begin{array}{c}\text { Average } \\
\text { belt width } \\
\text { (feet) }\end{array}$ & $\begin{array}{c}\text { Average } \\
\text { radius of } \\
\text { curvature } \\
\text { (feet) }\end{array}$ \\
\hline 1 & 13 & 292 & 100 & 33 \\
\hline 2 & 41 & 866 & 257 & 92 \\
\hline 3 & 6 & 403 & 135 & 35 \\
\hline 4 & 0 & 785 & 271 & 70 \\
\hline 5 & 100 & NA & NA & NA \\
\hline
\end{tabular}

in the watershed have added a large amount of uncertainty to these analyses.

\section{Thalweg Profiles}

Thalweg profiles (lines of maximum streambed descent) developed from the survey data were used to identify reaches that may be susceptible to further incision as well as to locate grade-control structures (fig. 8). No clear nickpoints (interruption or break in slope) were observed; generally, only areas immediately downstream from bridges or culverts showed localized incision. This was most apparent at a crossing over the unnamed tributary on reach 2 . Reaches 2 and 3 , on the unnamed tributary, had steeper thalweg gradients than the Cardwell Branch reaches. This is consistent with the typical longitudinal profile of a stream in which the headwater reaches have steeper slopes than the lower reaches (Schumm and others, 1984).

Eleven grade-control structures of various forms were observed in the study area. Eight of those were associated with culverts. Additionally, two rock piles (one near the mouth of reach 1 and one near the middle of reach 3) provided at least partial grade control, although these may not withstand large runoff events because of the possibility of the rocks being mobilized. A hardened low-water crossing for an abandoned road provided grade control in the upstream end of reach 4 . This crossing may be vulnerable to failure during a large runoff, although it appears to have been present for quite some time.

\section{Results of Ecological Assessment}

Rainfall-runoff substantially affects the water quality in Cardwell Branch. Additionally, dry stream channels and low dissolved oxygen levels may be reducing the amount of habitat available to the aquatic community. Consequently, these may be contributing to the degraded aquatic community observed at the monitoring site.

\section{Water Quality}

Water quality in Cardwell Branch is related to the amount of rainfall-runoff in the system. By storing and releasing rainfall-runoff more slowly to the stream system than the pre-reservoir condition, Yankee Hill Reservoir may be extending the duration of moderate concentrations of runoff-related constituents downstream.

Beneficial use designations and associated protections for Cardwell Branch downstream from Yankee Hill Reservoir include acute conditions for warm-water aquatic life, agricultural water supply, and aesthetics (Nebraska Department of Environmental Quality, 2002a). The beneficial use designations of Yankee Hill Reservoir are similar to those of Cardwell Branch, with added designation and protections for primary recreational contact (Nebraska Department of Environmental Quality, 2002a).

Chemical inputs to Cardwell Branch are largely from nonpoint sources, although two National Pollution Discharge Elimination System (NPDES) permits exist for point sources in the Cardwell Branch watershed (Nebraska Department of Environmental Quality, written commun., 2005). The first permit is associated with a power-generating station and allows discharges to a small tributary that flows north into Cardwell Branch between South 1st Street and Southwest 12th Street. Effluent from this source includes noncontact cooling
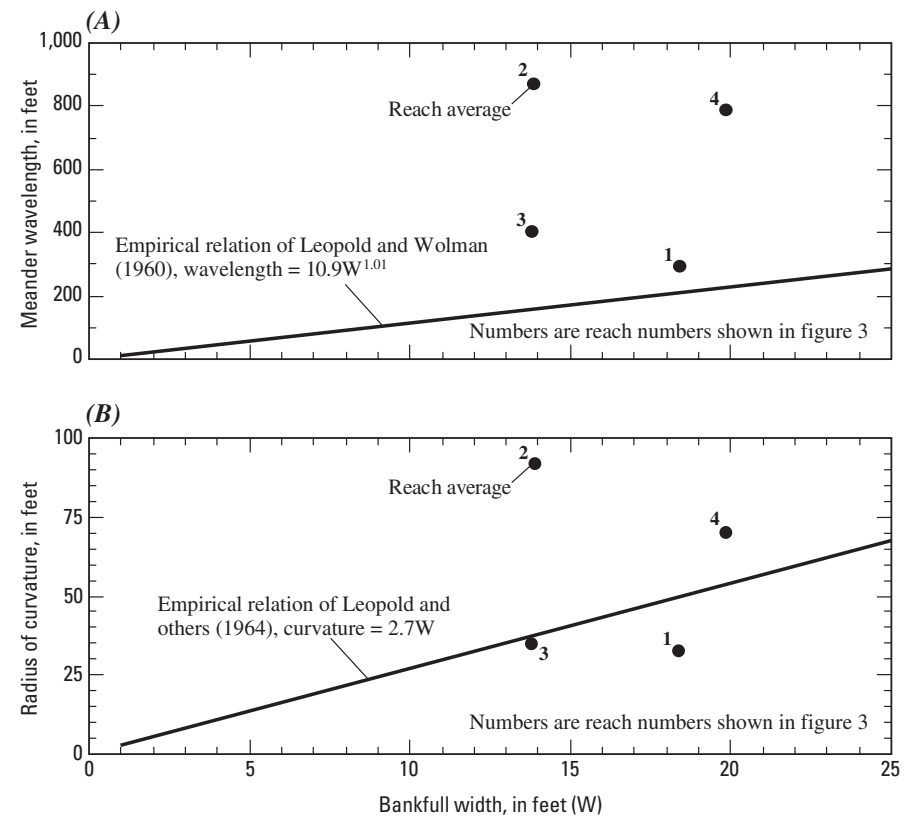

Figure 7. Meander geometry comparisons for reaches 1, 2, 3, and 4 in the Cardwell Branch study area, Nebraska. 


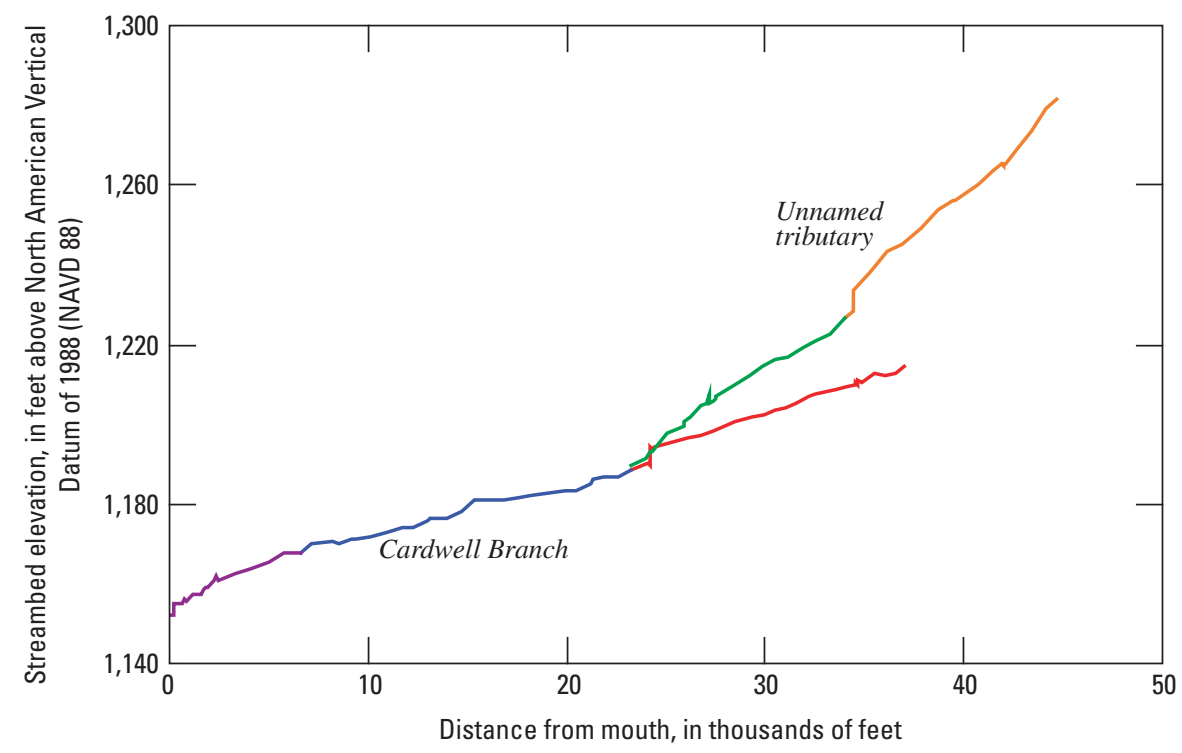

EXPLANATION

Geomorphic assessment reach

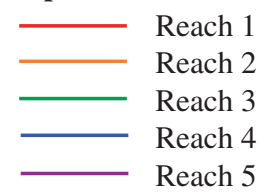

Reach 1

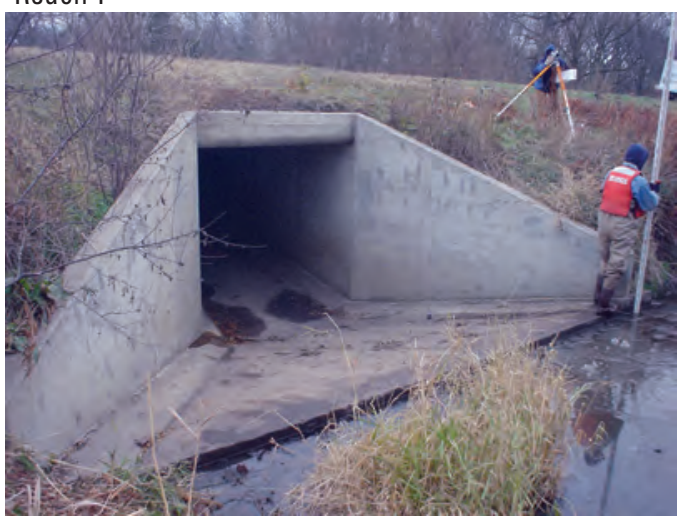

Grade control on the upstream side of Southwest 27th Street

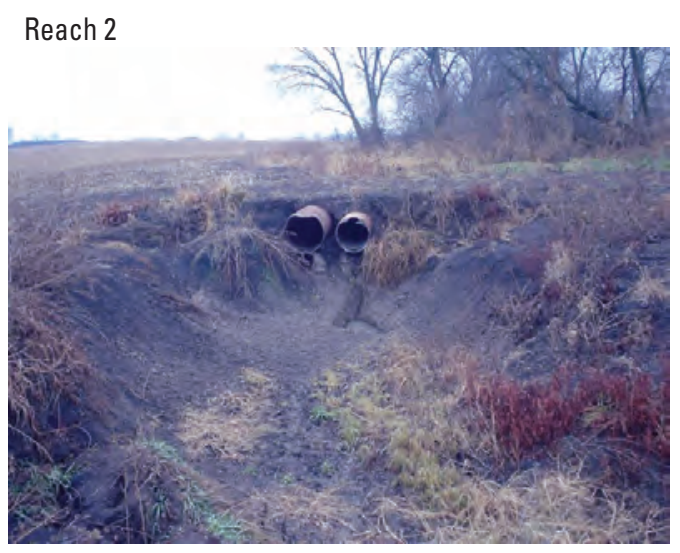

Farm crossing in section 29

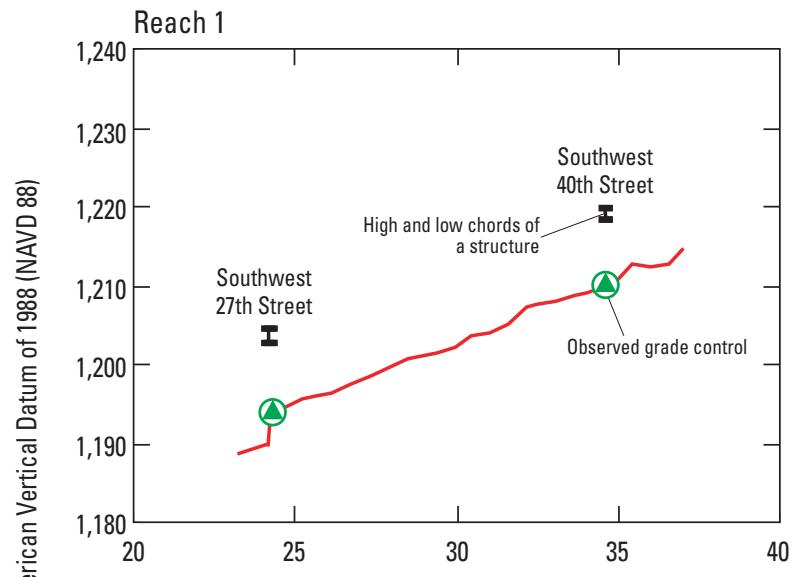

Figure 8. Thalweg profiles and supporting information for the Cardwell Branch study area, Nebraska. 
Reach 3

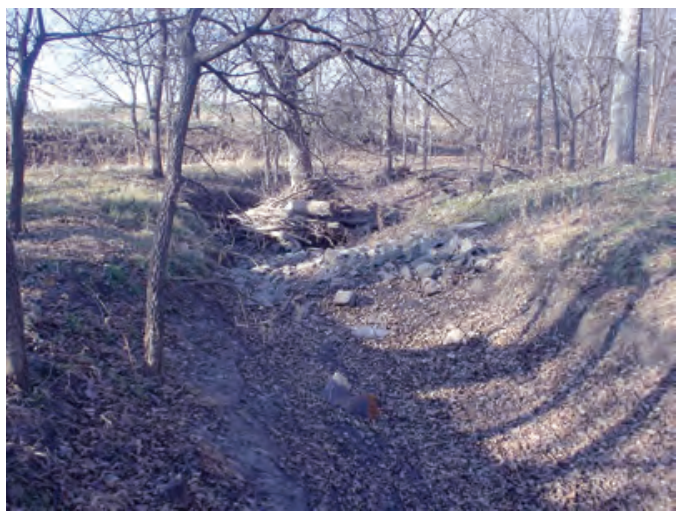

Grade control on the upstream side of Southwest 27th Street

\section{Reach 4}
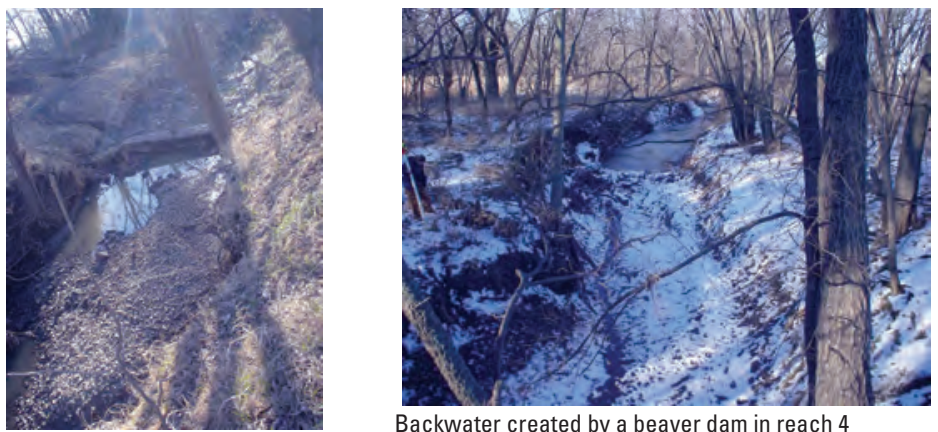

Remnants of an abandoned low-water crossing that is now providing margina grade control

Reach 5

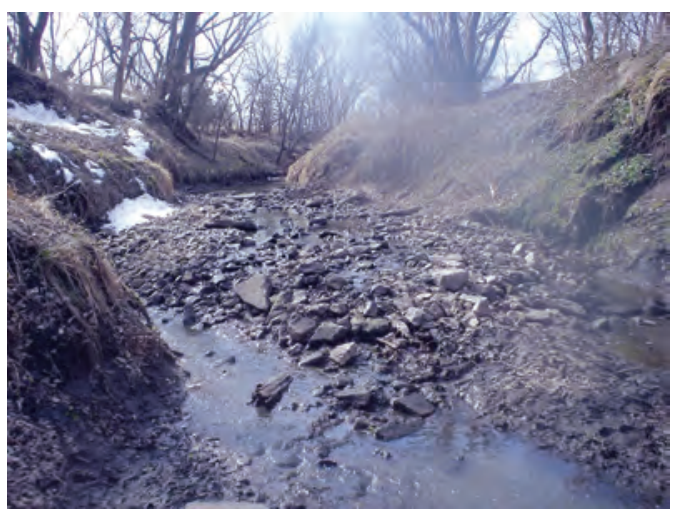

Piled rock at a hiking-trail crossing that is providing grade contro
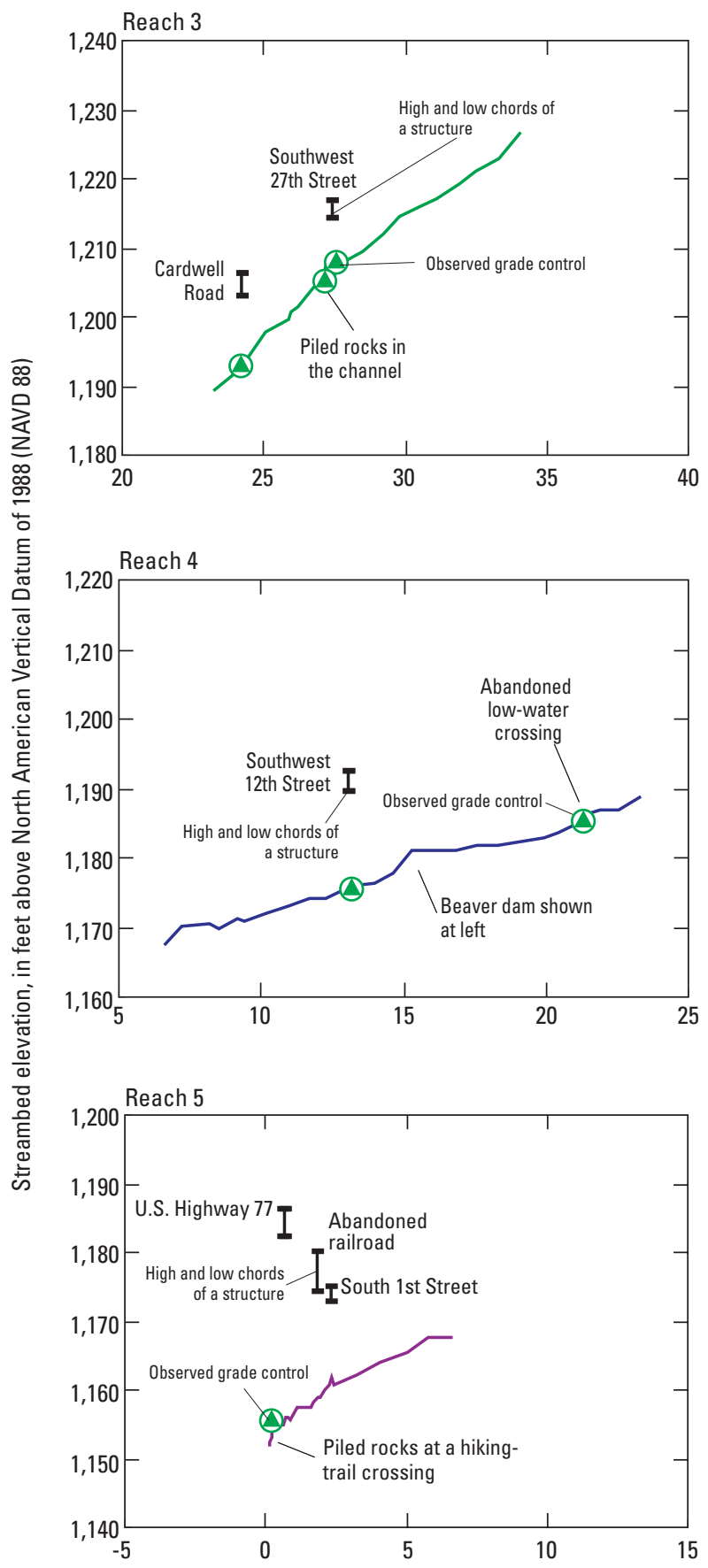

Distance from mouth, in thousands of feet

Figure 8. Thalweg profiles and supporting information for the Cardwell Branch study area, Nebraska.—Continued 
water and stormwater, air-cooler condensate, ice-tank cooling water, treated sanitary and floor drain waste, and reverseosmosis reject water from facility control processes. The second NPDES permit is associated with a domestic wastewater treatment lagoon located between Southwest 12th Street and Southwest 27th Street. The lagoon operator is permitted to discharge approximately $4 \mathrm{Mgal}$ into Cardwell Branch over 10 days for annual drawdown purposes with seasonal restrictions.

Nine water samples were collected at the monitoring site on Cardwell Branch (fig. 1) between August 2003 and November 2004. Selected water properties are summarized in table 13, and water-quality data are listed in Appendix 5. Comparisons are made to other water-quality data, both locally and nationally, but it should be noted that these nine samples over a 15-month period may not fully represent the variability in the water-quality condition of Cardwell Branch.

In general, samples were collected during three different flow conditions (table 13): (1) base flow, when very low streamflows were likely the result of shallow ground-water inputs; (2) runoff, when samples were collected within a day of rainfall; and (3) recession, when samples were collected more than a day after rainfall, but field conditions (such as higher streamflows and turbidity) indicated the recent occurrence of rainfall-runoff.

Although sampling frequency had targeted a range of streamflows, the maximum-sampled streamflow was $8.2 \mathrm{ft}^{3} / \mathrm{s}$. Although this was three orders of magnitude higher than the minimum-sampled streamflow of $0.01 \mathrm{ft}^{3} / \mathrm{s}$, water quality was not well characterized for higher streamflows. This is the result of the rapid response of Cardwell Branch to rainfall, and better characterization of the water quality for higher streamflows probably requires automated sampling.
Specific-conductance values from Cardwell Branch were compared with values collected from other streams in the area to describe the relative contribution that Cardwell Branch has on dissolved ions in Salt Creek, the receiving stream. Salt Creek contains high concentrations of dissolved ions, introduced from ground-water discharge from the highly saline Dakota Formation in the Lincoln area (Verstraeten, 1997), that cause higher conductivity during base-flow conditions relative to other streams in the area. Generally, this phenomenon increases in the downstream direction along Salt Creek in Lincoln and includes some tributaries to Salt Creek. On the basis of comparisons to published values of specific conductance at nearby sites during base-flow conditions (table 14), Cardwell Branch is not as greatly affected by the Dakota Formation as is Haines Branch, the watershed bordering Cardwell Branch to the north.

Nutrient concentrations in Cardwell Branch water-quality samples were substantially greater in runoff samples than in base-flow and recession samples (table 15). Average total phosphorus concentrations were much higher during runoff than in base-flow samples or recession samples, but orthophosphate concentrations generally were similar in all three sample types (table 15). For a local comparison, the mean concentrations of nitrate and total phosphorus in samples collected during 1994-95 from Salt Creek at Pioneers Boulevard (located approximately $5 \mathrm{mi}$ from the study area) were 1.45 milligrams per liter $(\mathrm{mg} / \mathrm{L})$ as nitrogen and $0.30 \mathrm{mg} / \mathrm{L}$ as phosphorus (Verstraeten, 1997). Nationwide, the sites in the National Urban Runoff Program (NURP) had a median nitrate value of $0.68 \mathrm{mg} / \mathrm{L}$ as nitrogen, with 90 percent of the sites having concentrations equal to or less than $1.75 \mathrm{mg} / \mathrm{L}$ as nitrogen (U.S. Environmental Protection Agency, 1983). The NURP sites had a median total phosphorus value of $0.33 \mathrm{mg} / \mathrm{L}$

Table 13. Summary of field conditions and water properties at the time of sampling at the Cardwell Branch monitoring site, Nebraska, $2003-04$.

[USGS station number 404413096431401; precipitation data were obtained from the Pioneers Boulevard bridge over Salt Creek (USGS station 06803080), located 5 miles northeast of the watershed; $\mathrm{ft}^{3} / \mathrm{s}$, cubic feet per second; NTRU, nephelometric turbidity ratio unit; $\mu \mathrm{S} / \mathrm{cm}$, microsiemens per centimeter at 25 degrees Celsius; mg/L, milligrams per liter; E, estimated value]

\begin{tabular}{|c|c|c|c|c|c|c|c|c|}
\hline $\begin{array}{c}\text { Date of } \\
\text { sample } \\
\text { (month/day/ } \\
\text { year) }\end{array}$ & $\begin{array}{c}\text { 7-day } \\
\text { antecedent } \\
\text { precipitation } \\
\text { total (inches) }\end{array}$ & $\begin{array}{c}\text { Streamflow } \\
\left(\mathrm{ft}^{3} / \mathrm{s}\right)\end{array}$ & $\begin{array}{l}\text { Turbidity } \\
\text { (NTRUs) }\end{array}$ & $\begin{array}{c}\text { Specific } \\
\text { conductance } \\
\text { ( } \mathrm{\mu S} / \mathrm{cm})\end{array}$ & $\begin{array}{c}\text { pH } \\
\text { (standard } \\
\text { units) }\end{array}$ & $\begin{array}{c}\text { Dissolved } \\
\text { oxygen } \\
\text { (mg/L) }\end{array}$ & $\begin{array}{c}\text { Water } \\
\text { temperature } \\
\text { (degrees } \\
\text { Celsius) }\end{array}$ & Flow type \\
\hline $8 / 28 / 2003$ & 0.09 & 0.01 & 12 & 693 & 7.8 & 2.4 & 22.7 & Base flow \\
\hline $12 / 15 / 2003$ & 0 & .01 & 20 & 732 & 7.8 & 10.8 & .5 & Base flow \\
\hline $2 / 4 / 2004$ & 0 & .01 & 17 & 780 & E 6.9 & 10.9 & -.8 & Base flow \\
\hline $3 / 1 / 2004$ & .46 & .84 & 65 & 460 & 7.5 & 10.3 & 1.6 & Recession \\
\hline $5 / 24 / 2004$ & 2.17 & 8.2 & 1,590 & 277 & 6.5 & 8.9 & 18.3 & Runoff \\
\hline $6 / 14 / 2004$ & 1.53 & 6.8 & 1,250 & 288 & 7.8 & 7.6 & 21.7 & Runoff \\
\hline $7 / 19 / 2004$ & .13 & .84 & 140 & 423 & 7.7 & 6.5 & 22.2 & Recession \\
\hline $8 / 25 / 2004$ & .92 & .1 & E 25 & 576 & 7.8 & 4.4 & 21.1 & Base flow \\
\hline $11 / 1 / 2004$ & 1.13 & 0.73 & 68 & 675 & 7.8 & 6.7 & 11.9 & Recession \\
\hline
\end{tabular}


Table 14. Average specific conductance at selected sites near Cardwell Branch, Nebraska.

$[\mu \mathrm{S} / \mathrm{cm}$, microsiemens per centimeter at 25 degrees Celsius]

\begin{tabular}{ccc}
\hline Site & USGS station number & $\begin{array}{c}\text { Average spe- } \\
\text { cific conductance } \\
\text { ( } \mathbf{S} / \mathbf{c m})\end{array}$ \\
\hline $\begin{array}{c}\text { Cardwell Branch at } \\
\text { South 1st Street }\end{array}$ & 404413096431401 & 695 \\
$\begin{array}{c}\text { Salt Creek at Pio- } \\
\text { neers Boulevard }\end{array}$ & 06803080 & 762 \\
$\begin{array}{c}\text { Haines Branch at } \\
\text { Van Dorn Street }\end{array}{ }^{2}$ & 06803097 & 5,513 \\
$\begin{array}{c}\text { Salt Creek at South } \\
\text { Street }\end{array}$ & 06803100 & 2,478 \\
\hline
\end{tabular}

${ }^{1}$ Only samples collected under base-flow conditions were used to compute the average specific conductance.

${ }^{2}$ Averages were computed from published values given in Kister and Mundorff (1963) and Verstraeten (1997).

as phosphorus, with 90 percent of the sites having concentrations equal to or less than $0.70 \mathrm{mg} / \mathrm{L}$ as phosphorus.

For the two runoff samples, chemical oxygen demand (COD) varied greatly, with one sample at $90 \mathrm{mg} / \mathrm{L}$ and the other at less than $10 \mathrm{mg} / \mathrm{L}$ (Appendix 5). By contrast, there was less variability in COD in the base-flow and recession samples. At Salt Creek at Pioneers Boulevard, the mean COD from four samples collected during 1994-95 was $40 \mathrm{mg} / \mathrm{L}$ and was $68 \mathrm{mg} / \mathrm{L}$ for one sample collected in August 1995 from Haines Branch at Van Dorn Street (located just north of the study area) (Verstraeten, 1997). At the NURP sites, the median COD was $65 \mathrm{mg} / \mathrm{L}$, with 90 percent of the sites having COD less than $140 \mathrm{mg} / \mathrm{L}$ (U.S. Environmental Protection Agency, 1983).

Like COD, biological oxygen demand (BOD) also increased during runoff (table 15). The median BOD reported for the NURP sites was $9 \mathrm{mg} / \mathrm{L}$, with 90 percent of the sites having BOD less than $15 \mathrm{mg} / \mathrm{L}$ (U.S. Environmental Protection Agency, 1983).

To maintain consistency with similar watershed studies (Olsson Associates and Wright Water Engineers, 2000), concentrations of total suspended solids (TSS) were determined for this study rather than suspended sediment (SS). TSS levels in Cardwell Branch were highest in the runoff samples and lowest in the base-flow samples (table 15). The median TSS concentration reported for the NURP sites was $100 \mathrm{mg} / \mathrm{L}$, with 90 percent of the sites having TSS less than $300 \mathrm{mg} / \mathrm{L}$ (U.S. Environmental Protection Agency, 1983).

Sedimentation in the Cardwell Branch likely is affected by Yankee Hill Reservoir. In general, reservoirs act as efficient sediment traps (Williams and Wolman, 1984). A comparison of sediment concentrations in Salt Creek before and after construction indicates that reservoirs may have affected the sediment load in Salt Creek. Kister and Mundorff (1963) assessed SS loads in Salt Creek at 27th Street in Lincoln, Nebraska (USGS station 06803500), finding that average daily SS concentrations of 100, 1,000, and 5,000 mg/L were exceeded 43, 17, and 6 percent of the time, respectively, between 1951 and 1954. Between 1962 and 1967, 11 reservoirs, including Yankee Hill Reservoir, were constructed in the Salt Creek watershed by the U.S. Army Corps of Engineers in response to two large floods in the early 1950s (Soenksen and

Table 15. Summary of selected water-quality constituents at the Cardwell Branch monitoring site, Nebraska, $2003-04$.

[USGS station 404413096431401; $\mu \mathrm{S} / \mathrm{cm}$, microsiemens per centimeter at 25 degrees Celsius; mg/L, milligrams per liter; E. coli, Escherichia coli; $\mu \mathrm{g} / \mathrm{L}$, micrograms per liter; E, estimated value]

\begin{tabular}{|c|c|c|c|c|c|c|c|}
\hline $\begin{array}{c}\text { Flow } \\
\text { condition }\end{array}$ & $\begin{array}{l}\text { Number of } \\
\text { samples for each } \\
\text { flow condition }\end{array}$ & $\begin{array}{c}\text { Average } \\
\text { specific } \\
\text { conductance } \\
\text { ( } \mathrm{S} S / \mathrm{cm})\end{array}$ & $\begin{array}{c}\text { Average } \\
\text { whole-water } \\
\text { chemical } \\
\text { oxygen } \\
\text { demand (mg/L) }\end{array}$ & $\begin{array}{c}\text { Average } \\
\text { whole-water } \\
\text { biological } \\
\text { oxygen } \\
\text { demand (mg/L) }\end{array}$ & $\begin{array}{c}\text { Average dis- } \\
\text { solved solids } \\
\text { (mg/L) }\end{array}$ & $\begin{array}{c}\text { Average } \\
\text { dissolved } \\
\text { nitrate (mg/L as } \\
\text { nitrogen) }\end{array}$ & $\begin{array}{c}\text { Average total } \\
\text { phosphorus } \\
\text { (mg/L as } \\
\text { phosphorus) }\end{array}$ \\
\hline Base flow & 4 & 695 & 20 & 2.3 & 435 & 0.28 & 0.48 \\
\hline Runoff & 2 & 283 & 50 & 7.8 & 167 & 3.03 & 1.21 \\
\hline Recession & 3 & 519 & 23 & 3.9 & 325 & .47 & .52 \\
\hline $\begin{array}{c}\text { Flow } \\
\text { condition }\end{array}$ & $\begin{array}{c}\text { Average } \\
\text { dissolved } \\
\text { orthophosphate } \\
\text { (mg/L as } \\
\text { phosphorus) }\end{array}$ & $\begin{array}{c}\text { E. coli }{ }^{1} \\
\text { (colonies per } \\
100 \text { milliliters } \\
\text { of water) }\end{array}$ & $\begin{array}{l}\text { Average total } \\
\text { suspended } \\
\text { solids (mg/L) }\end{array}$ & $\begin{array}{c}\text { Average } \\
\text { dissolved } \\
\text { atrazine ( } \mu \mathrm{g} / \mathrm{L})\end{array}$ & $\begin{array}{c}\text { Average } \\
\text { dissolved } \\
\text { metolachlor } \\
\text { ( } \mu \mathrm{g} / \mathrm{L})\end{array}$ & $\begin{array}{c}\text { Average } \\
\text { dissolved } \\
\text { arsenic ( } \mu \mathrm{g} / \mathrm{L})\end{array}$ & $\begin{array}{c}\text { Average } \\
\text { dissolved } \\
\text { manganese } \\
\text { (mg/L) }\end{array}$ \\
\hline Base flow & 0.343 & 200 & 27 & 0.357 & 0.229 & 10.3 & 600 \\
\hline Runoff & .192 & E 4,900 & 555 & 12.6 & 5.78 & 3.3 & 6.9 \\
\hline Recession & .295 & 760 & 86 & 1.66 & 1.42 & 10.0 & 580 \\
\hline
\end{tabular}

${ }^{1}$ Equipment malfunctions contaminated five E. coli samples collected prior to June 14, 2004. 
others, 1999). Daily SS concentrations measured at Salt Creek near Greenwood (USGS station 06803555) (U.S. Geological Survey, 2005) provide approximately comparable data for SS loading following reservoir construction. At this site, average daily SS concentrations of 100, 1,000, and 5,000 mg/L were exceeded 87,9 , and 1 percent of the time, respectively, between 1971 and 1976. Although there is uncertainty associated with this comparison between different locations, it may indicate that sediment is being trapped in the reservoirs. These SS concentrations also may indicate that the reservoir system has increased the frequency of moderate SS concentrations in Salt Creek but has reduced the frequency of high SS concentrations. This suggests that in the same way that a reservoir reduces peak streamflow by increasing the duration of the rainfall-runoff hydrograph (Collier and others, 1996), a similar effect may apply to SS concentrations. To extend this analogy to Cardwell Branch, Yankee Hill Reservoir may be reducing the maximum concentrations of SS (such as those in the runoff samples) by extending the time that moderate concentrations (such as those in the recession samples) are present downstream from the reservoir.

Although the trends in Salt Creek SS have probably occurred in the Cardwell Branch watershed, Gray and others (2000) point out that TSS and SS data should not be used interchangeably because of a negative bias in TSS data (especially as the proportion of sand-sized material increases).

Sediment loading to Yankee Hill Reservoir was studied by the Natural Resources Conservation Service (1993) using the Agricultural Nonpoint Source Pollution Model. Estimated sediment loads for the 100-, 20-, and 4-percent-frequency rainstorms (over a 24-hour duration) were 145, 454, and 986 tons, respectively (Natural Resources Conservation Service, 1993). Because of sediment and phosphorus loading, Yankee Hill Reservoir has been deemed impaired, and Total Maximum Daily Load regulations exist for both sediment and phosphorus for the lake (Nebraska Department of Environmental Quality, 2002b).

Of the pesticides analyzed, only atrazine and metolachlor were detected consistently (table 15). Both appear to be related to runoff, with runoff samples having the highest concentrations, and base-flow samples having the lowest concentrations.

Water samples were analyzed for a wide variety of wastewater compounds, including food additives, fragrances, antioxidants, flame retardants, plasticizers, industrial solvents, disinfectants, fecal sterols, polycyclic aromatic hydrocarbons (PAHs), and high-use domestic pesticides (Zaugg and others, 2002). Although trace amounts of some of these constituents were detected, large concentrations of wastewater compounds were not observed in the samples (Appendix 5).

\section{Aquatic Biota}

The sample of the aquatic community collected from the monitoring site on August 26, 2003, was typical of a degraded ecosystem. Although no lesions or deformities were observed (Appendix 6), fish specimens generally were of below-normal condition and were probably undernourished. In addition, the majority of observed aquatic-invertebrate and algal species were pollution tolerant.

\section{Fish}

A total of 107 fish were collected at the Cardwell Branch monitoring site on August 26, 2003. The sample was predominantly white crappie (Pomoxis annularis) or bluegill (Lepomis macrochirus) but also included green sunfish (Lepomis cyanellus), black bullhead (Ameiurus melas), yellow bullhead (Ameiurus natalis), river carpsucker (Carpiodes carpio), and channel catfish (Ictalurus punctatus) (fig. 9).

The large number of predator fish was unexpected, especially in the absence of small minnow species. This is likely related to renovations that were ongoing to Yankee Hill Reservoir prior to collection. Earlier in the spring of 2003, the water levels in the reservoir were drawn down, and many of the specimens collected for this study may have been introduced into the stream system by this process.

Relative weight $\left(W_{r}\right)$ ratios calculated for the individual fish collected in the Cardwell Branch watershed ranged from 69 to 127 percent but were 82 percent on average. Although $\mathrm{W}_{r}$ values have been shown to vary greatly with season in many species, largely because of spawning season effects, sample collection occurred several months after the spawning season for both white crappie and bluegill. Average $\mathrm{W}_{r}$ values for white crappie and bluegill were 81 and 83 percent, respectively, with very little variability $( \pm 5$ percent $)$ in both populations. This generally uniform, subnormal condition among all individuals indicates that impaired habitats or resource availability rather than intraspecies competition may be the cause of their condition. One habitat impairment that likely played an important role in community richness and condi-

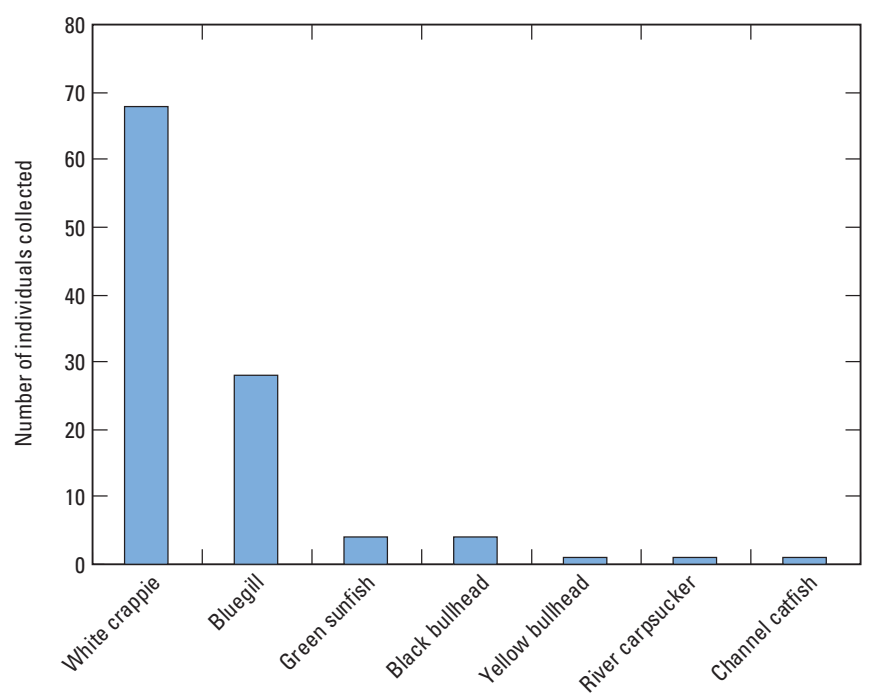

Figure 9. Number of fish collected at the Cardwell Branch monitoring site, Nebraska, August 26, 2003. 
tion is low dissolved oxygen (DO) levels. DO concentration was measured at the time of fish collection to be $1.44 \mathrm{mg} / \mathrm{L}$ and 2 days later was measured at $2.4 \mathrm{mg} / \mathrm{L}$ - lower than the nationally recommended minimum of $3.0 \mathrm{mg} / \mathrm{L}$ (U.S. Environmental Protection Agency, 1986) for the protection of aquatic life in warm-water habitats. Larger bluegill are primarily piscivores and secondarily insectivores, whereas white crappie are primarily insectivores (Barbour and others, 1999). The size of the individuals collected from Cardwell Branch would lead to the conclusion that both species were relying heavily on insects for nutrition, especially in the absence of small minnow species.

\section{Aquatic Invertebrates}

Several taxonomic richness metrics computed from the aquatic invertebrate community data (table 16) indicate a community with very few sensitive species, but dominated by the more adaptable Diptera order. Richness metrics showed that sensitive orders such as Plecoptera (stoneflies) were missing from this sample (table 16; Appendix 7). Along with Plecoptera, richness metrics for two other sensitive orders, Ephemeroptera (mayflies) and Tricoptera (caddisflies), were combined to yield a relatively low EPT index of 4. Because the EPT index typically increases as water quality improves, this result provided evidence of impairment in the stream. However, many Plecoptera species require cool, clear water not typically found in eastern Nebraska, and hence EPT richness metrics will automatically be lower in turbid warm-water streams than in areas with cool, clear water. With regard to dominant taxa, the order Diptera (midges, mosquitoes, gnats, and flies) was most common with midges being the most common species group. Dipterans are highly adaptable species, many of which are pollution tolerant (McCafferty, 1981).

\section{Algal Community}

The algal community associated with the August 2003 sampling of the monitoring site was composed of 6 genera of nondiatom algae and 65 species of diatoms (Appendix 8). The nondiatom algae included four genera of blue-green cyanobacteria algae (Geitlerinema sp., Hyella sp., Planktothrix sp., and Pseudanabaena sp.), one genus of green algae (Ankistrodesmus sp.), and one genus of euglenoid algae (Euglena sp.).

The majority of the algal population sample, however, was composed of diatom species. Of the 65 different diatom species categorized, four were only identifiable to the genus level. Various tolerance metrics were computed for the diatom species (table 17), that together indicate a pollution-tolerant algal community where the majority of species are autotrophic and prefer slightly alkaline, slightly saline, eutrophic systems with moderate to high levels of dissolved oxygen. Autotrophs rely on photosynthesis and require high levels of organic nitrogen (S.D. Porter, USGS, written com-
Table 16. Richness metrics associated with aquatic invertebrates sampled from the Cardwell Branch monitoring site, Nebraska, August 26, 2003.

[EPT, the orders Ephemeroptera, Plecoptera, and Trichoptera combined]

\begin{tabular}{|c|c|c|}
\hline Richness metric & $\begin{array}{l}\text { Number of } \\
\text { species }\end{array}$ & $\begin{array}{c}\text { Percentage } \\
\text { of } \\
\text { richness }\end{array}$ \\
\hline \multicolumn{3}{|c|}{ Taxa richness } \\
\hline Total richness & 35 & 100 \\
\hline EPT richness & 4 & 11 \\
\hline Ephemeroptera (mayfly) richness & 2 & 6 \\
\hline Plecoptera (stonefly) richness & 0 & 0 \\
\hline Trichoptera (caddisfly) richness & 2 & 6 \\
\hline Odonata richness & 2 & 6 \\
\hline Coleoptera richness & 2 & 6 \\
\hline Diptera richness & 13 & 37 \\
\hline Chironomidae (midge) richness & 9 & 26 \\
\hline Nonmidge Diptera richness & 4 & 11 \\
\hline Noninsect richness & 7 & 20 \\
\hline Molluscs and crustacean richness & 4 & 11 \\
\hline Gastropoda richness & 2 & 6 \\
\hline Bivalvia richness & 2 & 6 \\
\hline Amphipoda richness & 0 & 0 \\
\hline Oligochaeta richness & 1 & 3 \\
\hline Isoptera richness & 0 & 0 \\
\hline \multicolumn{3}{|c|}{ Functional-feeding group richness } \\
\hline Parasite richness & 0 & 0 \\
\hline Predator richness & 16 & 46 \\
\hline Omnivore richness & 0 & 0 \\
\hline Collector-gatherer richness & 5 & 14 \\
\hline Filtering-collector richness & 7 & 20 \\
\hline Scraper richness & 3 & 9 \\
\hline Shredder richness & 3 & 9 \\
\hline Piercer richness & 0 & 0 \\
\hline
\end{tabular}

mun., 2002). Although very low dissolved oxygen levels $(1.44 \mathrm{mg} / \mathrm{L})$ were measured in the backwater of the ecological sampling reach, oxygen requirements were moderate or higher for 83 percent of the classified species. The majority of species preferred $\beta$-mesosaprobic water, in which impairment from ammonia compounds was minimal (van Dam and others, 1994). Bahls' overall pollution index (Bahls, 1993) for the community was calculated as 2.07 where 1 is most tolerant and 3 is sensitive. Because so few Lange-Bertalot (1979) pollution tolerance values were available for species collected from Cardwell Branch, this metric was not used. Other information gathered about the diatom species found 


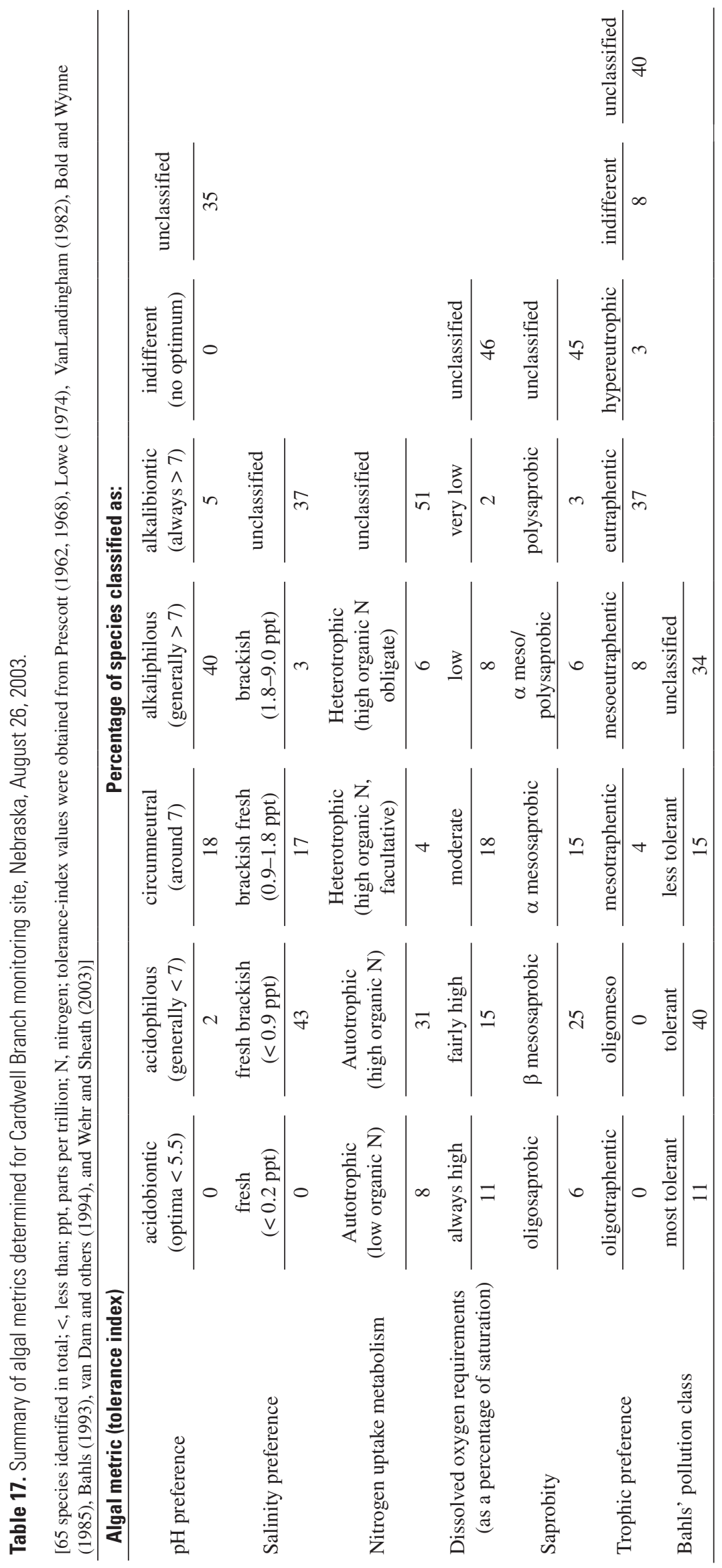


in the Cardwell Branch watershed show that most species are pinnate, benthic, motile, and non-nitrogen fixing.

\section{Aquatic Habitat}

A lack of available habitat may be contributing to the impaired aquatic community structure observed at the monitoring site. Even though potential habitat is present for aquatic biota, very low streamflows or dry channels, coupled with low dissolved oxygen levels, render the habitat unuseable to all but the most tolerant of organisms.

Habitat assessments done at the time of surveying indicated large amounts of woody debris and overhanging vegetation were present throughout the study area (table 18; Appendix 9). However, water was only consistently present in reaches 4 and 5 (fig. 3).

More detailed measurements of habitat at the monitoring site also provide some insight into habitat availability in areas containing water. Algal communities are dependent on light availability for photosynthetic processes. However, light penetration measurements indicated that at a depth of 7.8 in. below the water surface, only 12 percent of the light available at the surface remained, and only 1 percent penetrated to a depth of 10.6 in. As a result of low-light availability, much of the stream habitat below depths of 8 to $10 \mathrm{in}$. may be unusable to algal species. The fish and invertebrate communities are dependent on dissolved oxygen to survive, but the $1.44 \mathrm{mg} / \mathrm{L}$ concentration measured in the sampling reach, where a beaver dam had induced backwater, is very low in regard to aquaticlife requirements.

\section{Summary and Conclusions}

Cardwell Branch watershed, located near Lincoln, Nebraska, is a $16.3-\mathrm{mi}^{2}$ watershed where urban development is planned. As rural watersheds such as this one become urbanized, changes occur to the flood hydrology, stream-channel geometry, and ecological characteristics of those watersheds. An understanding of the conditions prior to urbanization is needed to detect changes in those conditions. Therefore, the USGS, in cooperation with the City of Lincoln and the Lower
Platte South Natural Resources District, performed an assessment of the $7.7 \mathrm{mi}^{2}$ of the Cardwell Branch watershed located downstream from Yankee Hill Reservoir to characterize the conditions of the hydrology, fluvial geomorphology, and stream ecology during 2003-04.

Hydrologic and hydraulic models were developed using the Hydrologic Modeling System (HEC-HMS) and River Analysis System (HEC-RAS) of the Hydraulic Engineering Center (U.S. Army Corps of Engineers). Estimates of peak streamflow and water-surface elevation were simulated for 24-hour-duration design rainstorms ranging from a 50-percent frequency to a 0.2-percent frequency. Typically, greater variability is associated with hydrologic simulations than hydraulic simulations, so efforts were focused on the hydrologic model by comparing results with both regional regression equations and local high-water marks. These comparative analyses were inconclusive, and in some cases, results were conflicting. Ultimately, two versions of the hydrologic model were developed. An initial HEC-HMS model was developed using the standardized parameter-estimation techniques associated with the Soil Conservation Service curve number method. An adjusted HEC-HMS model was also developed in which parameters were adjusted in order for the model output to better correspond to peak streamflows estimated from regional regression equations. Comparisons of peak streamflow from the two HEC-HMS models indicate that the initial HEC-HMS model may better agree with the regional regression equations for higher frequency storms, and the adjusted HEC-HMS model may agree more closely with regional regression equations for larger, rarer events. However, a lack of recorded streamflow data, coupled with conflicting results from comparisons with regional regression equations and local high-water marks, introduced considerable uncertainty concerning the model simulations. Using the HEC-RAS model to estimate water-surface elevations associated with the peak streamflow, the adjusted HEC-HMS model produced average increases in water-surface elevation of $0.2,1.1$, and $1.4 \mathrm{ft}$ for the 50-, 1-, and 0.2-percent-frequency rainstorms, respectively, as compared to those from the initial HEC-HMS model.

On the basis of evidence collected for this study, Cardwell Branch and its unnamed tributary appear to be undergoing incision that is somewhat tempered by the presence of grade controls and vegetation along the chan-

Table 18. Summary of aquatic habitat inventory in the Cardwell Branch study area, Nebraska, 2003-04.

\begin{tabular}{|c|c|c|c|c|c|c|}
\hline \multirow{2}{*}{$\begin{array}{l}\text { Geomorphic } \\
\text { reach (fig. 3) }\end{array}$} & \multicolumn{6}{|c|}{ Percentage of cross sections having the indicated habitat } \\
\hline & Woody debris & $\begin{array}{l}\text { Overhanging } \\
\text { vegetation }\end{array}$ & Undercut banks & Artificial habitat & No habitat & Wetted channel \\
\hline 2 & 33 & 83 & 17 & 0 & 0 & 6 \\
\hline 3 & 67 & 72 & 11 & 0 & 6 & 23 \\
\hline 5 & 90 & 80 & 10 & 10 & 0 & 100 \\
\hline
\end{tabular}


nel profile. Cross-sectional surveys and field assessments completed between November 2003 and March 2004 provided evidence of widespread imbalances of varying degree in the dynamic nature of the streams, and historical data indicated that as much as $2.3 \mathrm{ft}$ of incision have occurred since 1978 in some of the downstream reaches of Cardwell Branch. Field assessments indicated the predominance of silty materials in the stream channel and the stabilizing effect of woody, riparian vegetation on streambanks. Although evidence of streambank failures was commonly observed, 96 percent of the surveyed cross sections were classified as stable by planar and rotational failure analysis. Because soil geotechnical properties were assumed to be similar to those from nearby studies, and not measured directly, a possible explanation for this inconsistency may be the result of inadequate soil property characterization.

Several log jams were observed throughout the study area that may serve as quasi-grade controls during runoff of higher frequency (and lower magnitude). Similarly, many beaver dams were observed that may assist in returning incised streams to predisturbed conditions by causing aggradation. The process-based classification systems indicated that all classified reaches within the study area were unstable, incising, and widening, and the Rosgen classification system showed stream types of B6c in all but the most downstream reach, which was classified as type E6. Variability in the meander geometry indicates that variable recovery from past straightening coupled with the error typically associated with meander analysis led to inconclusive results for these analyses. No clear migrating nickpoints were observed from the thalweg profile; generally, only areas immediately downstream from bridges or culverts showed acute incision. Eleven gradecontrol structures of various forms were observed along the profile; eight of which were culverts.

Nine water-quality samples were collected between August 2003 and November 2004 near the mouth of the watershed and were categorized by the streamflow conditions at the time of sampling as being base-flow, runoff, or recession samples. Sediment-laden rainfall-runoff substantially affected the water quality in Cardwell Branch. The runoff samples imposed greater biochemical and chemical oxygen demands and had increased concentrations of several nutrient, bacteriological, sediment, and pesticide constituents. Although the storage of rainfall-runoff in Yankee Hill Reservoir serves to reduce flooding in downstream reaches of Cardwell Branch, it may also prolong the presence of runoffrelated constituents in those reaches.

Aquatic habitat assessments done throughout the study area revealed an ample supply of usable aquatic habitat substrate, but an overall lack of habitat availability because of low dissolved oxygen levels and low streamflows or dry channels. In August 2003, the aquatic community near the mouth of the stream was represented by undernourished fish, pollu- tion-tolerant Dipteran invertebrates, and pollution-tolerant, autotrophic algae.

This assessment of the Cardwell Branch watershed provides a baseline for future comparisons. Although there was considerable uncertainty (and subsequent variability) associated with the hydrologic assessment, it remains useful in gaging the effects of urbanization in the watershed. Streamchannel incision has occurred, but moderating effects from structures and vegetation also were identified in the watershed. The combined effects of exposure to rainfall-runoff and a lack of available habitat may have contributed to the degraded aquatic community observed at the monitoring site.

\section{References Cited}

American Public Health Association, 1980, Standard methods for the examination of water and wastewater (15th ed.): New York, American Public Health Association, p. 83.

Anderson, R.O., and Neumann, R.M., 1996, Length, weight, and associated structural indices, in Murphy, B.R., and Willis, D.W., eds., Fisheries techniques (2nd ed.): Bethesda, Maryland, American Fisheries Society, p. 447-482.

Arcement, G.J., Jr., and Schneider, V.R., 1989, Guide for selecting Manning's roughness coefficients for natural channels and flood plains: U.S. Geological Survey Water-Supply Paper 2339, 38 p.

Bagnold, R.A., 1966, An approach to the sediment transport problem from general physics: U.S. Geological Survey Professional Paper 422-I, 37 p.

Bahls, L.L., 1993, Periphyton bioassessment methods for Montana streams: Helena, Montana, Water Quality Bureau, Department of Health and Environmental Sciences, 69 p.

Barbour, M.T., Gerritsen, Jeroen, Snyder, B.D., and Stribling, J.B., 1999, Rapid bioassessment protocols for use in streams and wadeable rivers-periphyton, benthic macroinvertebrates and fish (2nd ed.): Washington, D.C., U.S. Environmental Protection Agency, Office of Water, EPA 841-B99-002, $322 \mathrm{p}$.

Beckman, E.W., and Hutchison, N.E., 1962, Floods in Nebraska on small drainage areas, magnitude and frequency: U.S. Geological Survey Circular 458, 33 p.

Bishop, A.W., 1955, The use of slip circle in the stability analysis of slopes: Geotechnique, v. 5, no. 1, p. 7-17.

Bister, T.J., Willis, D.W., Brown, M.L., Jordan, S.M., Neumann, R.M., Quist, M.C., and Guy, C.S., 1999, Development of standard weight $\left(\mathrm{W}_{s}\right)$ equations and standard length categories for 18 game and non-game fishes: South Dakota Cooperative Fish and Wildlife Research Unit, South Dakota State University, Technical Bulletin 12, 73 p. 
Bister, T.J., Willis, D.W., Brown, M.L., Jordan, S.M., Neumann, R.M., Quist, M.C., and Guy, C.S., 2000, Proposed standard weight $\left(\mathrm{W}_{\mathrm{s}}\right)$ equations and standard length categories for 18 warmwater nongame and riverine fish species: North American Journal of Fisheries Management, v. 20, p. 570-574.

Bledsoe, B.P., and Watson, C.C., 2001, Effects of urbanization on channel instability: Journal of the American Water Resources Association, v. 37, no. 2, p. 255-270.

Bold, H.C., and Wynne, M.J., 1985, Introduction to the algae_-structure and reproduction ( $2 \mathrm{~d}$ ed.): Englewood Cliffs, New Jersey, Prentice-Hall, 720 p.

Booth, D.B., 1990, Stream-channel incision following drainage-basin urbanization: Water Resources Bulletin, v. 26, no. 3, p. 407-417.

Booth, D.B., and Jackson, C.R., 1997, Urbanization of aquatic systems-degradation thresholds, stormwater detection, and the limits of mitigation: Journal of the American Water Resources Association, v. 33, no. 5, p. 1077-1090.

Camp, Dresser, and McKee, Inc. (CDM), 2005, Stevens Creek Watershed Master Plan: City of Lincoln, Nebraska, accessed April 9, 2006, at http://www.lincoln.ne.gov/city/pworks/ watrshed/mplan/stevens/index.htm

Charles, D.F., Knowles, Candia, and Davis, R.S., 2002, eds., Protocols for the analysis of algal samples collected as part of the U.S. Geological Survey National Water-Quality Assessment Program: Philadelphia, Pennsylvania, The Academy of Natural Sciences Report No. 02-06, 124 p.

Chow, V.T., 1959, Open-channel hydraulics: New York, McGraw-Hill, 680 p.

Chow, V.T., Maidment, D.R., and Mays, L.W., 1988, Applied hydrology: New York, McGraw-Hill, 572 p.

City of Lincoln, 2005, Planning Commission-Lincoln area draft land use, draft of November 9, 2005: City of Lincoln, Nebraska, accessed July 17, 2006, at http://www.lincoln. ne.gov/city/plan/cplrtp/mtg/110905/1109lu.pdf

Coduto, D.P., 1999, Geotechnical engineering_principles and practices: Englewood Cliffs, New Jersey, Prentice-Hall, $759 \mathrm{p}$.

Collier, Michael, Webb, R.H., and Schmidt, J.C., 1996, Dams and rivers-primer on the downstream effects of dams: U.S. Geological Survey Circular 1126, 94 p.

Cordes, K.E., and Hotchkiss, R.H., 1993, Design discharge of culverts: Lincoln, Nebraska, University of Nebraska Press, $97 \mathrm{p}$.

Cowan, W.L., 1956, Estimating hydraulic roughness coefficients: Agricultural Engineering, v. 37, no. 7, p. 473-475.
Cuffney, T.F., 2003, User's manual for the National WaterQuality Assessment Program invertebrate data analysis system (IDAS) software, version 3: U.S. Geological Survey Open-File Report 03-172, 114 p.

Cunge, J.A., 1969, On the subject of flood propagation method (Muskingum method): Journal of Hydraulics Research, v. 7, no. 2, p. 205-230.

Doan, J.H., 2000, Geospatial hydrologic modeling extension HEC-GeoHMS: U.S. Army Corps of Engineers, accessed May 19, 2005, at http://www.hec.usace.army.mil/software hec-hms/ documentation/HEC-GeoHMS11.pd]

Federal Emergency Management Agency, 2001, Flood insurance study, Lancaster County, Nebraska and incorporated areas, revision of September 21, 2001: Washington D.C., Federal Emergency Management Agency, 83 p., 84 pl.

Federal Emergency Management Agency, 2003, Guidelines and specifications for flood hazard mapping partners-Appendix C, Guidance for riverine flooding analyses and mapping: Federal Emergency Management Agency, accessed April 9, 2006, at http://www.fema.gov/pdf/fhm/ frm_gsac.pdf

Fishman, M.J., ed., 1993, Methods of analysis by the U.S. Geological Survey National Water Quality Laboratorydetermination of inorganic and organic constituents in water and fluvial sediments: U.S. Geological Survey Open-File Report 93-125, 217 p.

Fishman, M.J., and Friedman, L.C., 1989, Methods for determination of inorganic substances in water and fluvial sediments: U.S. Geological Survey Techniques of WaterResources Investigations, book 5, chap. A1, 545 p.

Fitzpatrick, F.A., Harris, M.A., Arnold, T.L., and Richards, K.D., 2004, Urbanization influences on aquatic communities in northeastern Illinois streams: Journal of the American Water Resources Association, v. 40, no. 2, p. 461-475.

Fitzpatrick, F.A., Waite, I.R., D’Arconte, P.J., Meador, M.R., Maupin, M.A., and Gurtz, M.E., 1998, Revised methods for characterizing stream habitat in the National Water-Quality Assessment Program: U.S. Geological Survey WaterResources Investigations Report 98-4052, 67 p.

Gray, J.R., Glysson, G.D., Turcios, L.M., and Schwarz, G.E., 2000, Comparability of suspended-sediment concentration and total suspended solids data: U.S. Geological Survey Water-Resources Investigations Report 00-4191, 14 p.

Hammer, T.R., 1972, Stream-channel enlargement due to urbanization: Water Resources Research, v. 8, no. 6, p. $1530-1540$. 
Hershfield, D.M., 1961, Rainfall frequency atlas of the United States for durations from 30 minutes to 24 hours and return periods from 1 to 100 years: Washington D.C., U.S. Department of Commerce, Weather Bureau, Technical Paper 40, $115 \mathrm{p}$.

Hollis, G.E., 1975, The effects of urbanization on floods of different recurrence intervals: Water Resources Research, v. 11 , no. 3 , p. 431-435.

Juracek, K.E., and Fitzpatrick, F.A., 2003, Limitations and implications of stream classification: Journal of the American Water Resources Association, v. 39, no. 3, p. 659-670.

Kister, L.R., and Mundorff, J.C., 1963, Sedimentation and chemical quality of water in Salt Creek Basin, Nebraska: U.S. Geological Survey Water-Supply Paper 1669-H, 47 p.

Knighton, A.D., 1998, Fluvial forms and processes-a new perspective: London, Oxford University Press, 383 p.

Konrad, C.P., 2003, Effects of urban development on floods: U.S. Geological Survey Fact Sheet FS-076-03, 4 p.

Krause, C.W., Lockard, Brendan, Newcomb, T.J., Kibler, David, Lohani, Vinod, and Orth, D.J., 2004, Predicting influences of urban development on thermal habitat in a warm water stream: Journal of the American Water Resources Association, v. 40, no. 6, p. 1645-1658.

Langbein, W.B., and Leopold, L.B., 1966, River meanders-theory of minimum variance: U.S. Geological Survey Professional Paper 422-H, 15 p.

Lange-Bertalot, Horst, 1979, Pollution tolerance of diatoms as a criterion for water quality estimation: Nova Hedwigia, v. 64 , p. 285-304.

Leopold, L.B., and Wolman, M.G., 1960, River meanders: Bulletin of the Geologic Society of America, v. 71, no. 6, p. 769-793.

Leopold, L.B., Wolman, M.G., and Miller, J.P., 1964, Fluvial processes in geomorphology: New York, Dover Publications, $522 \mathrm{p}$.

Lohnes, R.A., and Handy, R.L., 1968, Slope angles in friable loess: Journal of Geology, v. 76, no. 3, p. 247-258.

Lowe, R.L., 1974, Environmental requirements and pollution tolerance of freshwater diatoms: Cincinnati, Ohio, U.S. Environmental Protection Agency, National Environmental Research Center, Office of Research and Development, EPA-670/4-74-005, 334 p.

McCafferty, W.P., 1981, Aquatic entomology: Boston, Jones and Bartlett Publishers, 448 p.
McCullough, M.C., Harper, J. L., Eisenhauer, D.E., and Dosskey, M.G., 2004, Channel aggradation by beaver dams on a small agricultural stream in eastern Nebraska, in D’Ambrosio, J.L., ed., Self-sustaining solutions for streams, wetlands, and watersheds-Proceedings of the September 2004 conference: St. Paul, Minnesota, American Society of Agricultural and Biological Engineers, 416 p.

Moore, C.T., 1915, Drainage districts of southeastern Nebraska, in Barbour, E.H., ed., An account of the Nebraska Geological Survey to 1912: Lincoln, Nebraska Geological Survey Miscellaneous Papers, v. 7, p. 125-164.

Moulton, S.R., II, Kennen, J.G., Goldstein, R.M., and Hambrook, J.A., 2002, Revised protocols for sampling algal, invertebrate, and fish communities as part of the National Water-Quality Assessment Program: U.S. Geological Survey Open-File Report 02-150, 75 p.

Moulton, S.R., II, Carter, J.L., Grotheer, S.A., Cuffney, T.F., and Short, T.M., 2000, Methods of analysis by the U.S. Geological Survey National Water Quality Laboratoryprocessing, taxonomy, and quality control of benthic macroinvertebrate samples: U.S. Geological Survey Open-File Report 00-212, 49 p.

Naiman, R.J, Johnston, C.A, and Kelley, J.C., 1988, Alteration of North American streams by beaver: Bioscience, v. 38, no. 11 , p. 753-762.

National Weather Service, 2006, Precipitation frequency data server: National Weather Service, accessed April 9, 2006, at http://hdsc.nws.noaa.gov/hdsc/pfds/index.html

Natural Resources Conservation Service, 1993, Yankee Hillnonpoint assessment, cooperative river basin study: Lincoln, Nebraska, U.S. Department of Agriculture, 61 p.

Natural Resources Conservation Service, 1999, Soil survey geographic (SSURGO) database for Lancaster County, Nebraska: Natural Resources Conservation Service, accessed April 20, 2005, at http://www.ncgc.nrcs.usda. gov/products/datasets/ssurgo/

Nebraska Department of Environmental Quality, 2002a, Title 117-Nebraska surface water quality standards: Nebraska Department of Environmental Quality, accessed April 19, 2006, at http://www.deq.state.ne.us/ RuleAndR.nsf/pages/117-TOC

Nebraska Department of Environmental Quality, 2002b, Total maximum daily loads for Yankee Hill Lake_Lancaster County, Nebraska: Lincoln, Nebraska Department of Environmental Quality Planning Unit, Water Quality Division, $20 \mathrm{p}$. 
Olsson Associates and Wright Water Engineers, 2000, Beal Slough stormwater master plan: City of Lincoln, Nebraska, accessed April 9, 2006, at http://www.lincoln.ne.gov/city/ pworks/watrshed/mplan/bealslmp/index.htm

Omernick, J.M., 1987, Ecoregions of the conterminous United States (map supplement): Annals of the Association of American Geographers, v. 77, no. 1, p. 118-125.

Osterkamp, W.R., and Hedman, E.R., 1982, Perennial-streamflow characteristics related to channel geometry and sediment in the Missouri River basin: U.S. Geological Survey Professional Paper 1242, 37 p.

Poff, N.L., Allan, J.D., Bain, M.B., Karr, J.R., Prestegaard, K.L., Richter, B.D., Sparks, R.E., and Stromberg, J.C., 1997, The natural flow regime: a paradigm for river conservation and restoration: BioScience, v. 47, no. 11, p. 769-784.

Prescott, G.W., 1962, Algae of the western Great Lakes area (revised ed.): Dubuque, Iowa, William C. Brown Publishers, $977 \mathrm{p}$.

Prescott, G.W., 1968, The algae—a review: Boston, Houghton Mifflin, 436 p.

Rosgen, D.L., 1994, A classification of natural rivers: Catena, v. 22, p. 169-99.

Rosgen, D.L., 1996, Applied river morphology: Pagosa Springs, Colorado, Wildland Hydrology, 390 p.

Rus, D.L., Dietsch, B.J., and Simon, Andrew, 2003, Streambed adjustment and channel widening in eastern Nebraska: U.S. Geological Survey Water-Resources Investigations Report 03-4003, 63 p.

Saunders, William, 2000, Preparation of DEMs for use in environmental modeling analysis, in Maidment, D.R., and Djokic, Dean, eds., Hydrologic and hydraulic modeling support with geographic information systems: Redlands, California, ESRI Press, p. 29-51.

Schumm, S.A., 1960, The shape of alluvial channels in relation to sediment type: U.S. Geological Survey Professional Paper 352-B, p. 17-30.

Schumm, S.A., Harvey, M.D., and Watson, C.C., 1984, Incised channels-morphology, dynamics, and control: Littleton, Colorado, Water Resources Publications, 200 p.

Shields, F.D., Jr., Copeland, R.R., Klingeman, P.C., Doyle, M.W., and Simon, Andrew, 2003, Design for stream restoration: Journal of Hydraulic Engineering, v. 129, no. 8, p. 575-584.

Simon, Andrew, 1989, A model of channel response in disturbed alluvial channels: Earth Surface Processes and Landforms, v. 14, p. 11-26.
Simon, Andrew, and Collison, A.J.C., 2002, Quantifying the mechanical and hydrologic effects of riparian vegetation on streambank stability: Earth Surface Processes and Landforms, v. 27, no. 5, p. 527-546.

Simon, Andrew, Curini, Andrea, Darby, S.E., and Langendoen, E.J., 1999, Streambank mechanics and the role of bank and near-bank processes in incised channels, in Darby, S.E., and Simon, Andrew, eds., Incised river channels: New York, Wiley, p. 123-152.

Simon, Andrew, Doyle, M.W., Kondolf, G.M., Shields F.D., Jr., Rhoads, B.L., Grant, G.E., Fitzpatrick, F.A., Juracek, K.E., McPhillips, Munsell, and MacBroom, J.G., 2005, How well do the Rosgen classification and associated "natural channel design" methods integrate and quantify fluvial processes and channel response, in Proceedings of the 2005 World Water and Environmental Resources Congress, May 2005, Anchorage, Alaska: Reston, Virginia, American Society of Civil Engineers, 615 p.

Soenksen, P.J., Miller, L.D., Sharpe, J.B., and Watton, J.R., 1999, Peak-flow frequency relations and evaluation of the peak-flow gaging network in Nebraska: U.S. Geological Survey Water-Resources Investigations Report 99-4032, $48 \mathrm{p}$.

Soenksen P.J., Turner, M.J., Dietsch, B.J., and Simon, Andrew, 2003, Stream bank stability in eastern Nebraska: U.S. Geological Survey Water-Resources Investigations Report 03-4265, 102 p.

Soil Conservation Service, 1981, Land resource regions and major land resource areas of the United States (revision of 1965 ed.): U.S. Department of Agriculture, Soil Conservation Service Agricultural Handbook 296, , 156 p., 1 pl.

Soil Conservation Service, 1986, Urban hydrology for small watersheds: U.S. Department of Agriculture, Natural Resources Conservation Service Technical Release 55, $164 \mathrm{p}$.

Soil Conservation Service, 1993, Yankee Hill nonpoint assessment cooperative river basin study: U.S. Department of Agriculture, Soil Conservation Service, $61 \mathrm{p}$.

Spangler, M.G., and Handy, R.L., 1973, Soil engineering (3d ed.): New York, Intext Educational Publishers, 748 p.

Strahm, B.J., and Admiraal, D.M., 2005, Regression equations: Lincoln, Nebraska, University of Nebraska, Department of Civil Engineering, accessed February 17, 2006, at http://www.nlc.state.ne.us/epubs/R6000/B016.0104-2005. bdj, $121 \mathrm{p}$.

U.S. Army Corps of Engineers, 1994, Engineering and design — topographic surveying: U.S. Army Corps of Engineers Engineering Manual EM 1110-1-1005, 110 p. 
U.S. Army Corps of Engineers, 2001, Hydrologic modeling system (HEC-HMS) documentation (version 2.2.2): Davis, California, Hydraulic Engineering Center document, accessed November 29, 2004, at http://www.hec.usace.army. mil/software/hec-hms/

U.S. Army Corps of Engineers, 2002, River analysis system (HEC-RAS) documentation (version 3.1.2): Davis, California, Hydraulic Engineering Center document, accessed May 23, 2005, at http://www.hec.usace.army.mil/software/ hec-ras/hecras-hecras.html

U.S. Army Corps of Engineers, 2003, Engineering and design-NAVSTAR global positioning system surveying: U.S. Army Corps of Engineers Engineering Manual EM 1110-1-1003, 469 p.

U.S. Census Bureau, 2005, Fact sheet for Lincoln, Nebraska: U.S. Census Bureau, 2005 American Community Profile, accessed February 10, 2006, at http://factfinder.census.gov

U.S. Environmental Protection Agency, 1983, Final report of the nationwide urban runoff program: Washington, D.C., U.S. Environmental Protection Agency, Water Planning Division, EPA 832-R-83-112, 200 p.

U.S. Environmental Protection Agency, 1986, Ambient water quality criteria for dissolved oxygen: Washington, D.C., U.S. Environmental Protection Agency, Office of Water, EPA 440/5-86-003, 46 p., accessed July 17, 2006, at http://www.epa.gov/waterscience/criteria/wqcriteria.html

U.S. Environmental Protection Agency, 1999, Guidelines establishing test procedures for the analysis of oil and grease and non-polar material under the clean water act and resource conservation and recovery act; final rule: Washington, D.C., U.S. Environmental Protection Agency, accessed February 19, 2007, at http://www.epa.gov/fedrgstr/ EPA-WATER/1999/May/Day-14/w12163.htm

U.S. Environmental Protection Agency, 2002 , Method 1603-Escherichia coli in water by membrane filtration using modified membrane-thermotolerant Escherichia coli agar: Washington, D.C. , U.S. Environmental Protection Agency, EPA 821-R-02-23, 9 p.

U.S. Geological Survey, 2005, Suspended-sediment database-daily values of suspended sediment and ancillary data: U.S. Geological Survey, accessed February 2, 2005, at http://co.water.usgs.gov/sediment/seddatabase.cfm

U.S. Geological Survey, 2006, National Water Information System: U.S. Geological Survey, accessed June 12, 2006, at http://waterdata.usgs.gov/nwis
U.S. Geological Survey, variously dated, National field manual for the collection of water-quality data: U.S. Geological Survey Techniques of Water-Resources Investigations, book 9, chaps. A1-A9, available online at http://pubs.water.usgs.gov/twri9A

van Dam, Herman, Mertens, Adrienne, and Sinkeldam, Jos, 1994, A coded checklist and ecological indicator values of freshwater diatoms from the Netherlands: Netherlands Journal of Aquatic Ecology, v. 28, no. 1, p. 117-133.

VanLandingham, S.L., 1982, Guide to the identification, environmental requirements and pollution tolerance of freshwater blue-green algae (Cyanophyta): Cincinnati, Ohio, U.S. Environmental Protection Agency, Environmental Monitoring and Support Laboratory, Office of Research and Development, EPA-600/3-82-073, 341 p.

Vermont Agency of Natural Resources, 2004, Vermont stream geomorphic assessment-Appendix H, Meander geometry: Vermont Agency of Natural Resources, accessed March 13, 2006, at http://www.vtwaterquality.org/rivers/docs/ assessmenthandbooks/rv_apxhmeandergeometry.pdf, $4 \mathrm{p}$.

Verstraeten, I.M., 1997, Streamflow gain-and-loss measurements and water-quality data of Salt Creek and its tributaries near Lincoln, Nebraska, 1994-95: U.S. Geological Survey Open-File Report 96-551, 66 p.

Ward, A.D., and Trimble, S.W., 2004, Environmental hydrology (2nd ed.): Boca Raton, Florida, Lewis Publishers, $465 \mathrm{p}$.

Wehr, J.D., and Sheath, R.G., eds., 2003, Freshwater algae of North America-ecology and classification: San Diego, California, Academic Press, Elsevier Science (USA), 918 p.

Williams, G.P., 1978, Bank-full discharge of rivers: Water Resources Research, v. 14, no. 6, p. 1141-1154.

Williams, G.P., 1986, River meanders and channel size: Journal of Hydrology, v. 88, p. 147-164.

Williams, G.P., and Wolman, M.G., 1984, Downstream effects of dams on alluvial rivers: U.S. Geological Survey Professional Paper 1286, 83 p.

Wohl, Ellen, Angermeier, P.L., Bledsoe, Brian, Kondolf, G.M., MacDonnell, Larry, Merritt, D.M., Palmer, M.A., Poff, N.L., and Tarboton, David, 2005, River restoration: Water Resources Research, v. 41, no. W10301, p. 1-12.

Wolman, M.G., and Miller, J.P., 1960, Magnitude and frequency of forces in geomorphic processes: Journal of Geology, v. 68, p. 54-74. 
Zarriello, P.J., 1998, Comparison of nine uncalibrated runoff models to observed flows in two small urban watersheds, in Proceedings of the First Federal Interagency Hydrologic Modeling Conference, Las Vegas, Nevada, April 19-23, 1998: Subcommittee on Hydrology of the Interagency Advisory Committee on Water Data, v. 2, p. 163-170.

Zaugg, S.D., Sandstrom, M.W., Smith, S.G., and Fehlberg, K.M., 1995, Methods of analysis by the U.S. Geological Survey National Water Quality Laboratory-determination of pesticides in water by $\mathrm{C}-18$ solid-phase extraction and capillary-column gas chromatography/mass spectrometry with selected-ion monitoring: U.S. Geological Survey Open-File Report 95-181, 49 p.
Zaugg, S.D., Smith, S.G., Schroeder, M.P., Barber, L.B., and Burkhardt, M.R., 2002, Methods of analysis by the U.S. Geological Survey National Water Quality Laboratorydetermination of wastewater compounds by polystyrenedivinylbenzene solid-phase extraction and capillary-column gas chromatography/mass spectrometry: U.S. Geological Survey Water-Resources Investigations Report 01-4186, $37 \mathrm{p}$. 


\section{Appendixes}


Appendix 1. Channel geometry characteristics for cross sections surveyed between November 2003 and March 2004 in the Cardwell Branch study area.

[XSID, cross-section identifier; NAVD 88, North American Vertical Datum of 1988; C, Cardwell Branch; T1, unnamed tributary]

\begin{tabular}{|c|c|c|c|c|c|c|c|c|c|}
\hline XSID & $\begin{array}{l}\text { Geo- } \\
\text { morphic } \\
\text { reach } \\
\text { (fig. 3) }\end{array}$ & Stream & $\begin{array}{c}\text { Stream } \\
\text { distance } \\
\text { (feet above } \\
\text { mouth) }\end{array}$ & $\begin{array}{c}\text { Channel } \\
\text { height } \\
\text { (feet) }\end{array}$ & $\begin{array}{c}\text { Average } \\
\text { bank } \\
\text { angle } \\
\text { (degrees) }\end{array}$ & $\begin{array}{c}\text { Channel } \\
\text { width } \\
\text { (feet) }\end{array}$ & $\begin{array}{c}\text { Thalweg } \\
\text { elevation } \\
\text { (feet above } \\
\text { NAVD 88) }\end{array}$ & $\begin{array}{c}\text { Bankfull } \\
\text { depth (feet) }\end{array}$ & $\begin{array}{c}\text { Bankfull } \\
\text { width (feet) }\end{array}$ \\
\hline $\mathrm{C}-23-01$ & 5 & $\mathrm{C}$ & 1,163 & 15.0 & 19 & 100.3 & $1,157.5$ & 8.4 & 29.9 \\
\hline C-RR-EX & 5 & $\mathrm{C}$ & 1,614 & 13.2 & 28 & 105.4 & $1,157.6$ & 1.7 & 8.3 \\
\hline C-1st-EX & 5 & $\mathrm{C}$ & 2,099 & 12.6 & 36 & 50.3 & $1,160.0$ & 2.7 & 17.9 \\
\hline C-1st-APP & 5 & $\mathrm{C}$ & 2,418 & 10.6 & 27 & 55.6 & $1,160.6$ & 3.0 & 18.1 \\
\hline $\mathrm{C}-22-57$ & 5 & $\mathrm{C}$ & 3,274 & 5.9 & 33 & 45.3 & $1,162.3$ & 3.0 & 18.9 \\
\hline C- $-22-56$ & 5 & $\mathrm{C}$ & 4,097 & 7.9 & 36 & 36.2 & $1,163.9$ & 4.4 & 15.5 \\
\hline C-22-52 & 4 & $\mathrm{C}$ & 7,169 & 4.6 & 47 & 28.4 & $1,170.1$ & 1.5 & 21.5 \\
\hline C-22-51 & 4 & $\mathrm{C}$ & 8,189 & 7.0 & 47 & 31.9 & $1,170.5$ & 1.9 & 17.9 \\
\hline C-22-06 & 4 & $\mathrm{C}$ & 8,522 & 8.5 & 31 & 48.0 & $1,170.0$ & 5.9 & 24.5 \\
\hline C $-22-50$ & 4 & $\mathrm{C}$ & 9,183 & 7.7 & 41 & 32.8 & $1,171.4$ & 2.8 & 17.5 \\
\hline C-22-05 & 4 & $\mathrm{C}$ & 9,402 & 6.6 & 24 & 51.0 & $1,170.9$ & 6.8 & 26.6 \\
\hline C-22-04 & 4 & $\mathrm{C}$ & 10,117 & 8.2 & 25 & 52.2 & $1,171.8$ & 8.3 & 32.1 \\
\hline C-22-03 & 4 & $\mathrm{C}$ & 10,956 & 4.8 & 25 & 48.1 & $1,173.0$ & 6.4 & 35.1 \\
\hline $\mathrm{C}-22-02$ & 4 & $\mathrm{C}$ & 11,721 & 5.7 & 38 & 26.9 & $1,174.0$ & 1.3 & 14.6 \\
\hline C-21-04 & 4 & $\mathrm{C}$ & 16,046 & 5.5 & 32 & 44.6 & $1,181.0$ & 1.6 & 21.5 \\
\hline $\mathrm{C}-21-05$ & 4 & $\mathrm{C}$ & 16,846 & 6.3 & 32 & 34.1 & $1,181.1$ & 1.4 & 14.0 \\
\hline C-21-06 & 4 & $\mathrm{C}$ & 17,595 & 6.0 & 33 & 34.1 & $1,181.7$ & 1.4 & 15.5 \\
\hline $\mathrm{C}-21-07$ & 4 & $\mathrm{C}$ & 18,278 & 5.9 & 34 & 34.9 & $1,181.9$ & 6.2 & 25.6 \\
\hline $\mathrm{C}-21-55$ & 4 & $\mathrm{C}$ & 19,912 & 8.9 & 39 & 33.7 & $1,183.1$ & 2.1 & 11.9 \\
\hline $\mathrm{C}-21-54$ & 4 & $\mathrm{C}$ & 20,461 & 9.2 & 44 & 23.6 & $1,183.6$ & 2.2 & 10.9 \\
\hline C-21-53-DS & 4 & $\mathrm{C}$ & 21,197 & 7.1 & 44 & 29.4 & $1,185.0$ & 2.1 & 11.6 \\
\hline C-21-53-US & 4 & $\mathrm{C}$ & 21,292 & 6.7 & 45 & 26.4 & $1,186.1$ & 2.8 & 16.6 \\
\hline $\mathrm{C}-21-52$ & 4 & $\mathrm{C}$ & 21,901 & 5.7 & 36 & 26.6 & $1,186.8$ & 4.2 & 16.3 \\
\hline C-21-51 & 4 & $\mathrm{C}$ & 22,557 & 8.3 & 38 & 31.1 & $1,187.0$ & 2.7 & 11.9 \\
\hline $\mathrm{C}-21-50$ & 1 & $\mathrm{C}$ & 23,271 & 8.3 & 40 & 32.0 & $1,188.7$ & 3.1 & 10.9 \\
\hline C-27TH-EX & 1 & $\mathrm{C}$ & 24,105 & 7.3 & 36 & 36.9 & $1,190.0$ & 2.5 & 13.7 \\
\hline
\end{tabular}


Appendix 1. Channel geometry characteristics for cross sections surveyed between November 2003 and March 2004 in the Cardwell Branch study area.-Continued

[XSID, cross-section identifier; NAVD 88, North American Vertical Datum of 1988; C, Cardwell Branch; T1, unnamed tributary]

\begin{tabular}{|c|c|c|c|c|c|c|c|c|c|}
\hline XSID & $\begin{array}{c}\text { Geo- } \\
\text { morphic } \\
\text { reach } \\
\text { (fig. 3) }\end{array}$ & Stream & $\begin{array}{c}\text { Stream } \\
\text { distance } \\
\text { (feet above } \\
\text { mouth) }\end{array}$ & $\begin{array}{c}\text { Channel } \\
\text { height } \\
\text { (feet) }\end{array}$ & $\begin{array}{c}\text { Average } \\
\text { bank } \\
\text { angle } \\
\text { (degrees) }\end{array}$ & $\begin{array}{c}\text { Channel } \\
\text { width } \\
\text { (feet) }\end{array}$ & $\begin{array}{l}\text { Thalweg } \\
\text { elevation } \\
\text { (feet above } \\
\text { NAVD 88) }\end{array}$ & $\begin{array}{c}\text { Bankfull } \\
\text { depth (feet) }\end{array}$ & $\begin{array}{c}\text { Bankfull } \\
\text { width (feet) }\end{array}$ \\
\hline C-20-18 & 1 & $\mathrm{C}$ & 24,465 & 4.4 & 18 & 97.6 & $1,194.1$ & 2.4 & 15.5 \\
\hline C-20-17 & 1 & $\mathrm{C}$ & 25,215 & 5.0 & 16 & 58.1 & $1,195.6$ & 3.0 & 19.4 \\
\hline C-20-15 & 1 & $\mathrm{C}$ & 26,088 & 5.2 & 29 & 33.4 & $1,196.5$ & 2.5 & 15.2 \\
\hline C-20-14 & 1 & $\mathrm{C}$ & 26,730 & 6.0 & 24 & 38.3 & $1,197.3$ & 3.3 & 16.0 \\
\hline C-20-13 & 1 & $\mathrm{C}$ & 27,366 & 2.1 & 23 & 43.7 & $1,198.5$ & 2.8 & 16.4 \\
\hline $\mathrm{C}-20-12$ & 1 & $\mathrm{C}$ & 27,916 & 4.9 & 25 & 38.1 & $1,199.6$ & 1.9 & 12.3 \\
\hline C-20-08 & 1 & $\mathrm{C}$ & 30,479 & 5.2 & 31 & 26.9 & $1,203.7$ & 1.4 & 9.8 \\
\hline C-20-07 & 1 & $\mathrm{C}$ & 30,992 & 7.5 & 20 & 50.2 & 1,203.9 & 2.8 & 9.0 \\
\hline C-20-06 & 1 & $\mathrm{C}$ & 31,587 & 5.0 & 24 & 36.2 & $1,205.2$ & 2.1 & 10.0 \\
\hline $\mathrm{C}-20-05$ & 1 & $\mathrm{C}$ & 32,162 & 6.7 & 21 & 47.2 & $1,207.2$ & 2.1 & 10.9 \\
\hline C-20-04 & 1 & $\mathrm{C}$ & 32,529 & 5.3 & 21 & 33.2 & $1,207.6$ & 2.4 & 19.3 \\
\hline C-20-03 & 1 & $\mathrm{C}$ & 33,064 & 4.6 & 28 & 31.3 & $1,207.9$ & 2.7 & 18.6 \\
\hline $\mathrm{C}-20-02$ & 1 & $\mathrm{C}$ & 33,605 & 6.3 & 23 & 43.2 & $1,208.6$ & 2.6 & 25.2 \\
\hline C-20-01 & 1 & $\mathrm{C}$ & 34,004 & 6.7 & 17 & 63.6 & $1,209.1$ & 1.7 & 14.7 \\
\hline C-19-04 & 1 & $\mathrm{C}$ & 36,563 & 4.8 & 32 & 33.2 & $1,212.7$ & 6.0 & 28.1 \\
\hline T1-21-50 & 3 & $\mathrm{~T} 1$ & 23,285 & 10.0 & 25 & 67.3 & $1,189.4$ & 3.2 & 14.1 \\
\hline $\mathrm{T} 1-21-51$ & 3 & $\mathrm{~T} 1$ & 23,948 & 5.9 & 39 & 21.7 & $1,191.7$ & 3.5 & 16.1 \\
\hline T1-CARDDR-APP & 3 & $\mathrm{~T} 1$ & 24,313 & 8.5 & 31 & 52.8 & $1,193.3$ & 3.2 & 11.2 \\
\hline $\mathrm{T} 1-21-52$ & 3 & $\mathrm{~T} 1$ & 25,034 & 5.1 & 22 & 54.8 & $1,197.8$ & 1.2 & 7.9 \\
\hline $\mathrm{T} 1-21-53$ & 3 & $\mathrm{~T} 1$ & 25,879 & 9.1 & 24 & 82.1 & $1,199.6$ & 2.9 & 11.9 \\
\hline T1-21-06 & 3 & $\mathrm{~T} 1$ & 26,003 & 4.5 & 27 & 22.2 & $1,200.7$ & 1.7 & 9.4 \\
\hline $\mathrm{T} 1-21-54$ & 3 & $\mathrm{~T} 1$ & 26,203 & 4.6 & 46 & 20.0 & $1,201.6$ & 2.6 & 11.9 \\
\hline T1-21-05 & 3 & $\mathrm{~T} 1$ & 26,752 & 3.5 & 26 & 20.0 & $1,204.5$ & 2.0 & 15.8 \\
\hline T1-21-04 & 3 & $\mathrm{~T} 1$ & 27,081 & 4.1 & 47 & 18.3 & $1,205.1$ & 4.5 & 18.3 \\
\hline T1-21-03 & 3 & $\mathrm{~T} 1$ & 27,119 & 3.5 & 31 & 34.7 & $1,205.9$ & 3.7 & 34.7 \\
\hline $\mathrm{T} 1-21-02$ & 3 & $\mathrm{~T} 1$ & 27,160 & 2.7 & 18 & 31.3 & $1,207.4$ & 1.9 & 19.4 \\
\hline
\end{tabular}


Appendix 1. Channel geometry characteristics for cross sections surveyed between November 2003 and March 2004 in the Cardwell Branch study area.-Continued

[XSID, cross-section identifier; NAVD 88, North American Vertical Datum of 1988; C, Cardwell Branch; T1, unnamed tributary]

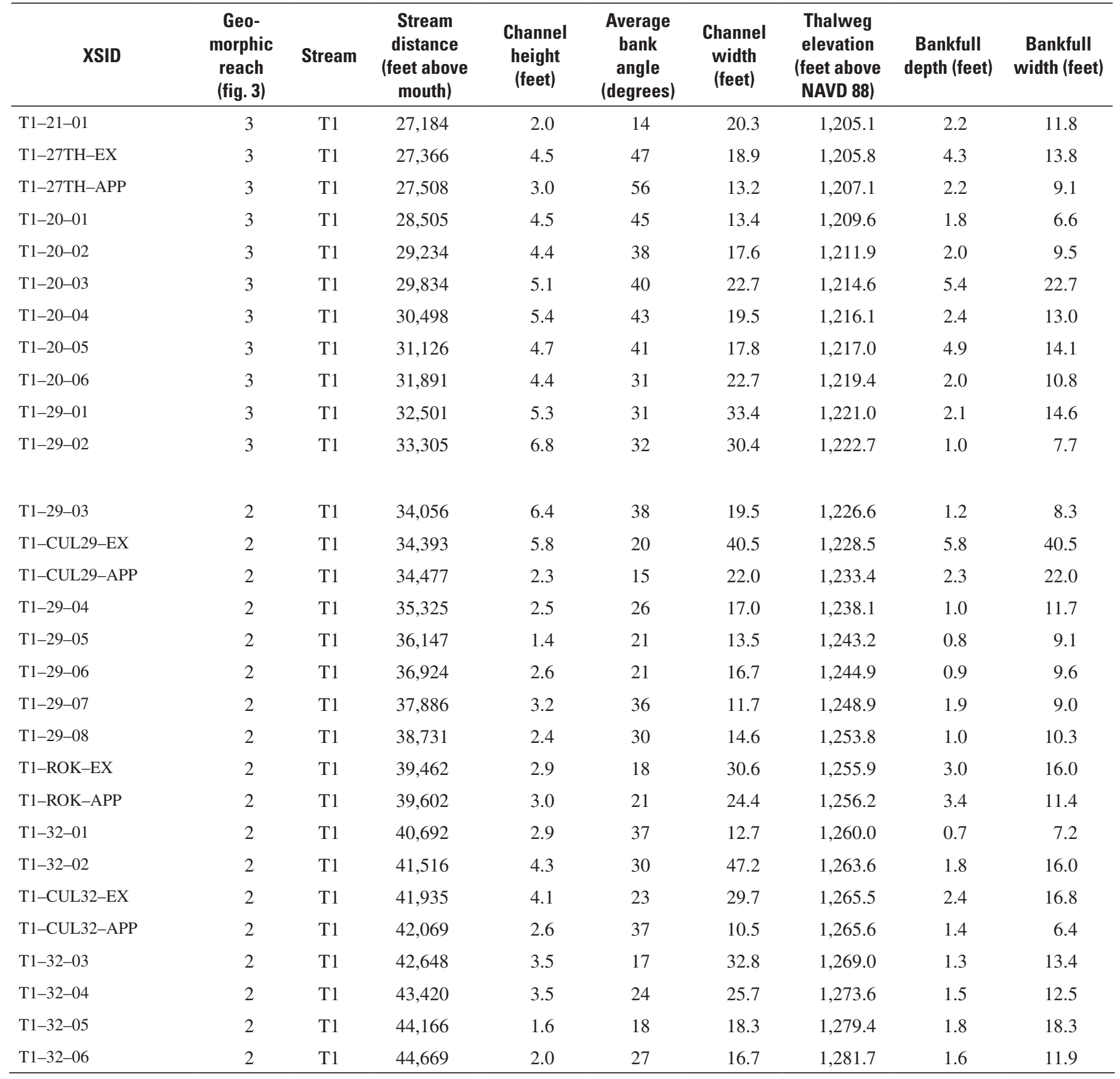




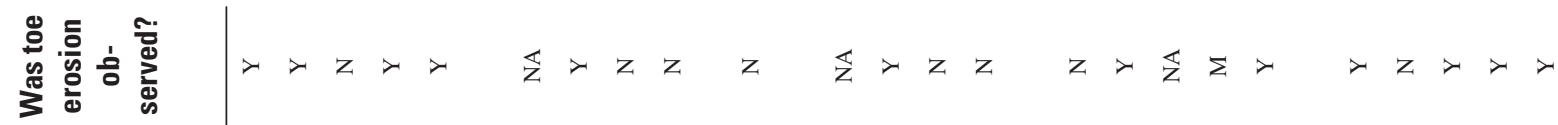

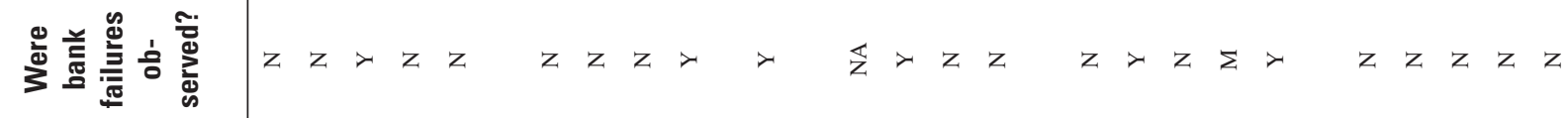

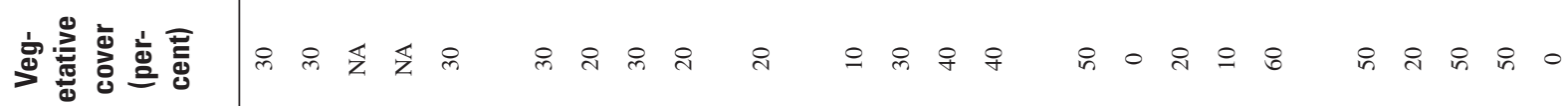

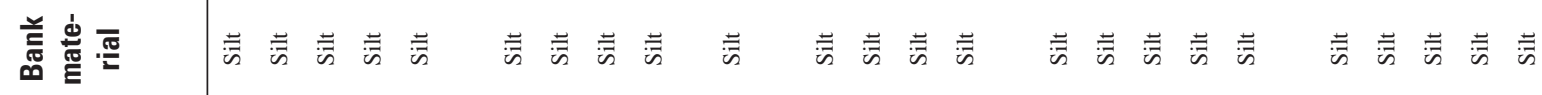

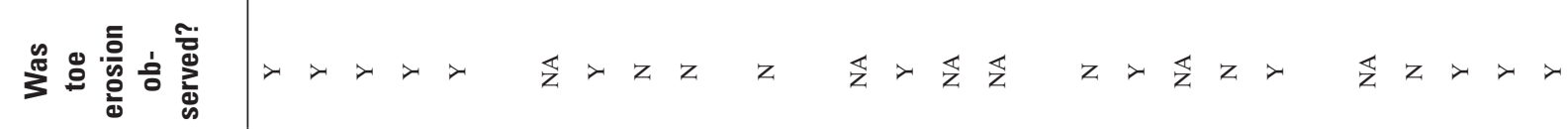

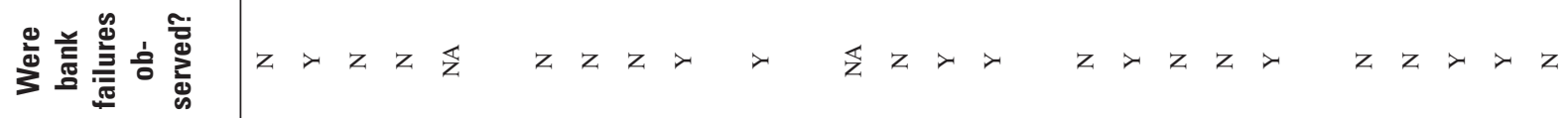

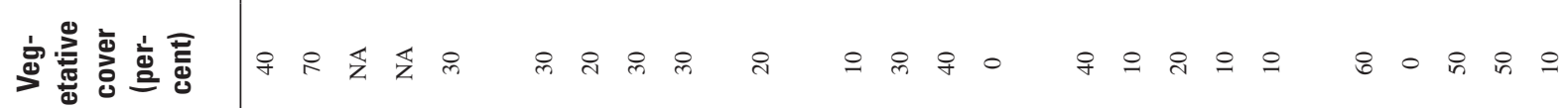

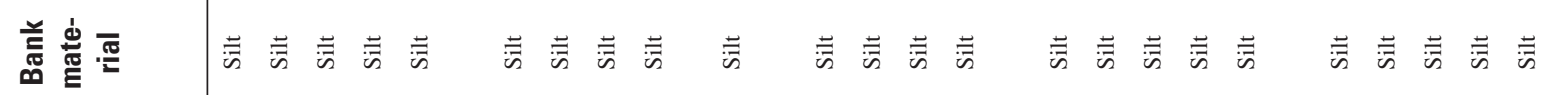

\section{D}

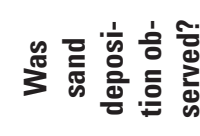

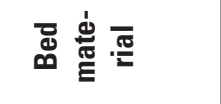

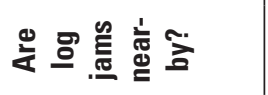

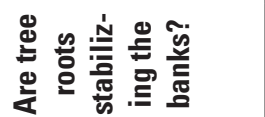

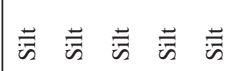

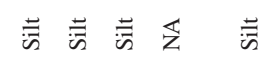
$z \overleftrightarrow{z} \searrow \succ$ $>z z>$ $\succ$ $\varangle>z z$

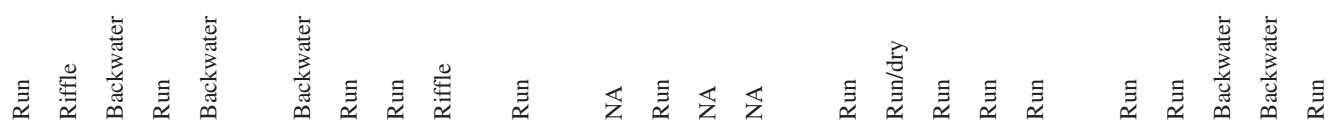

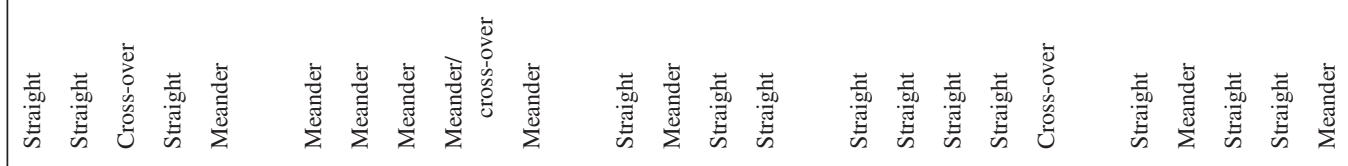

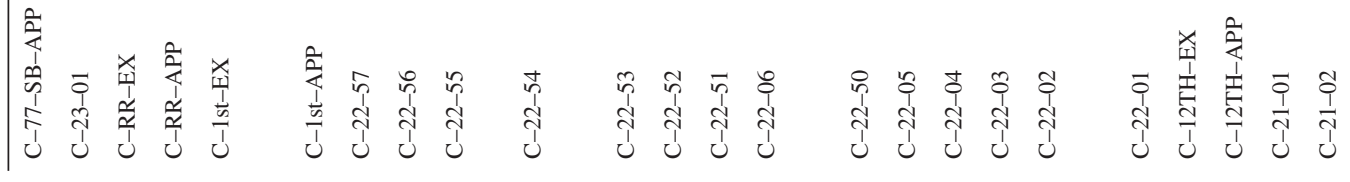




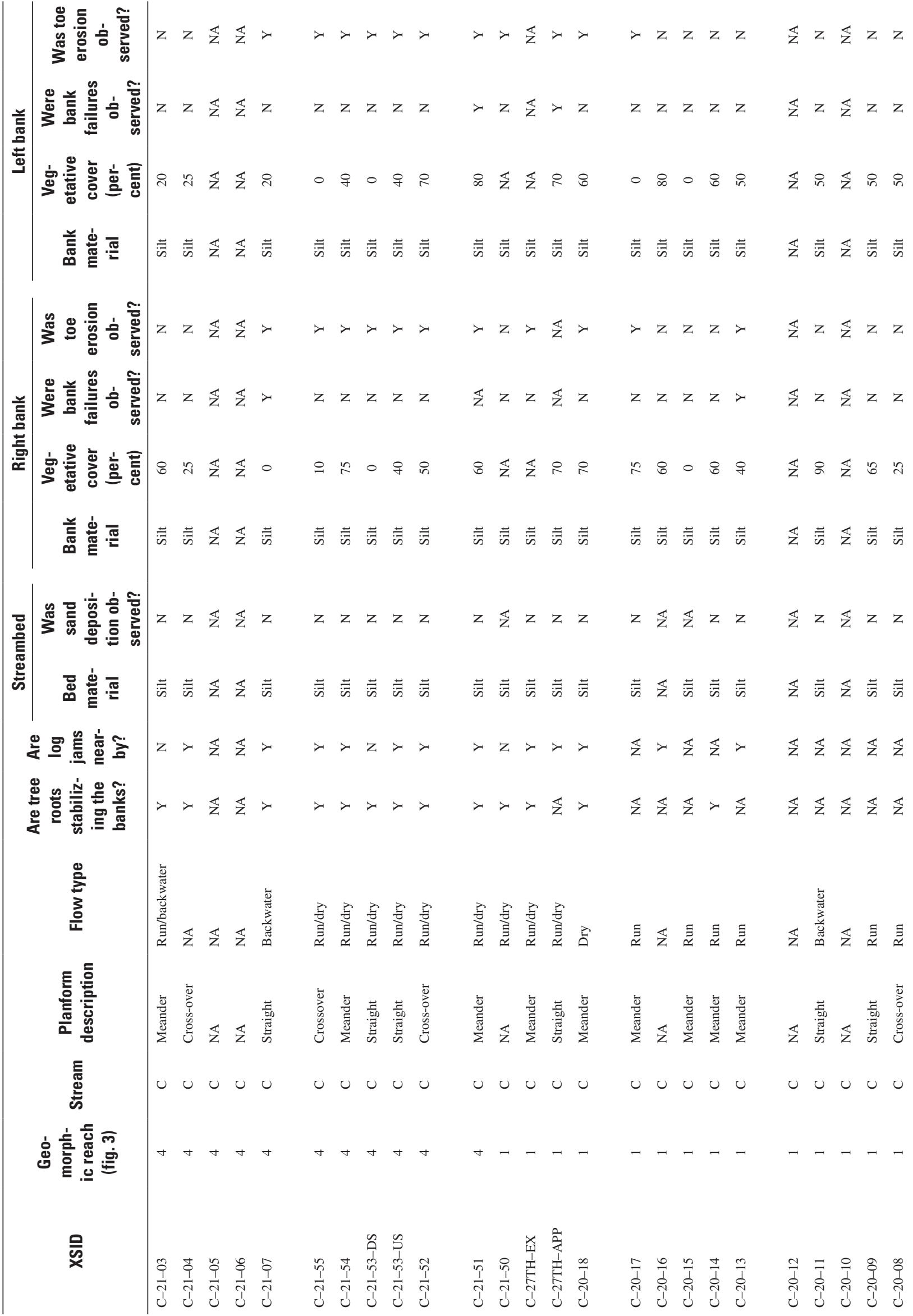




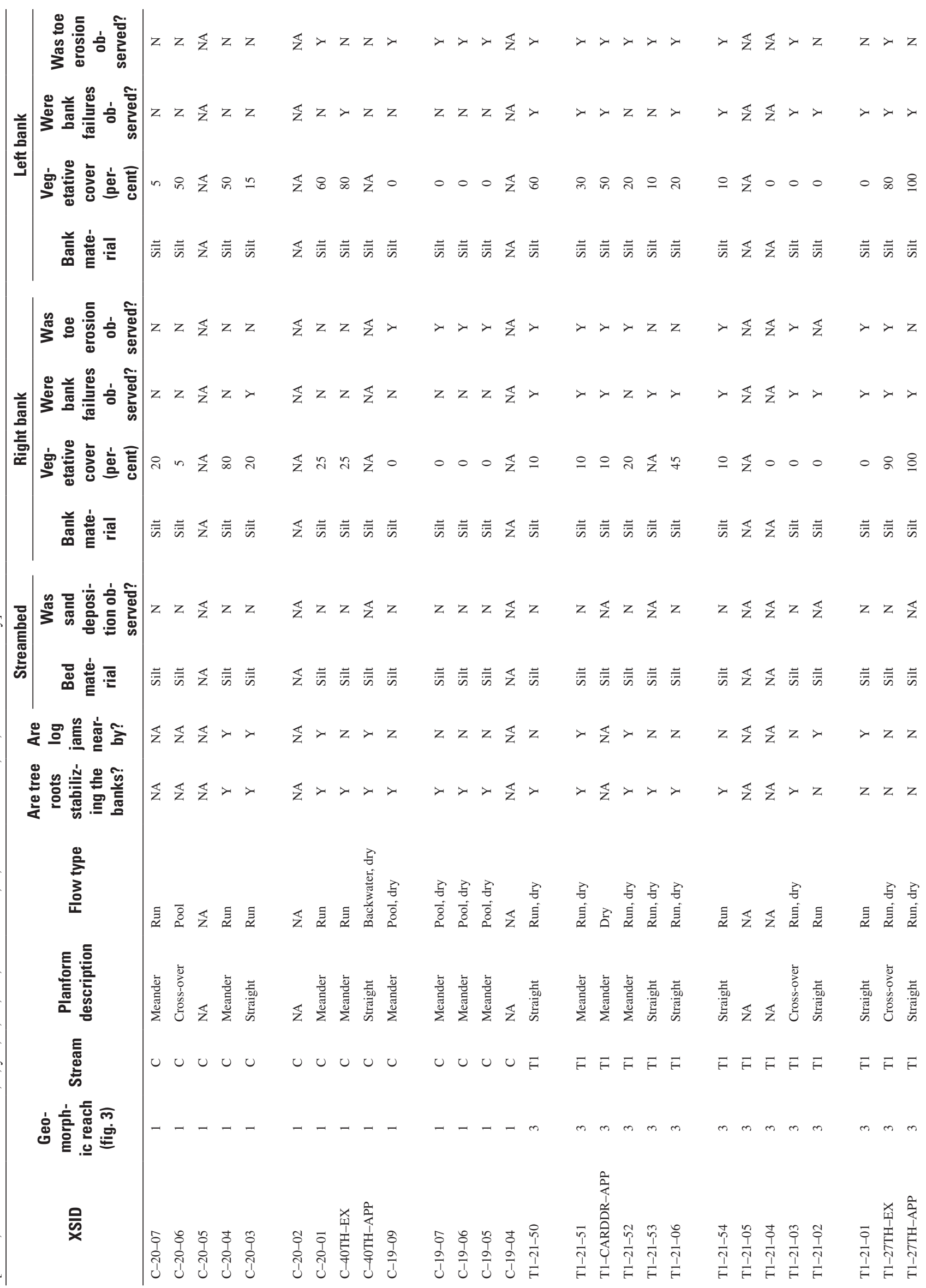




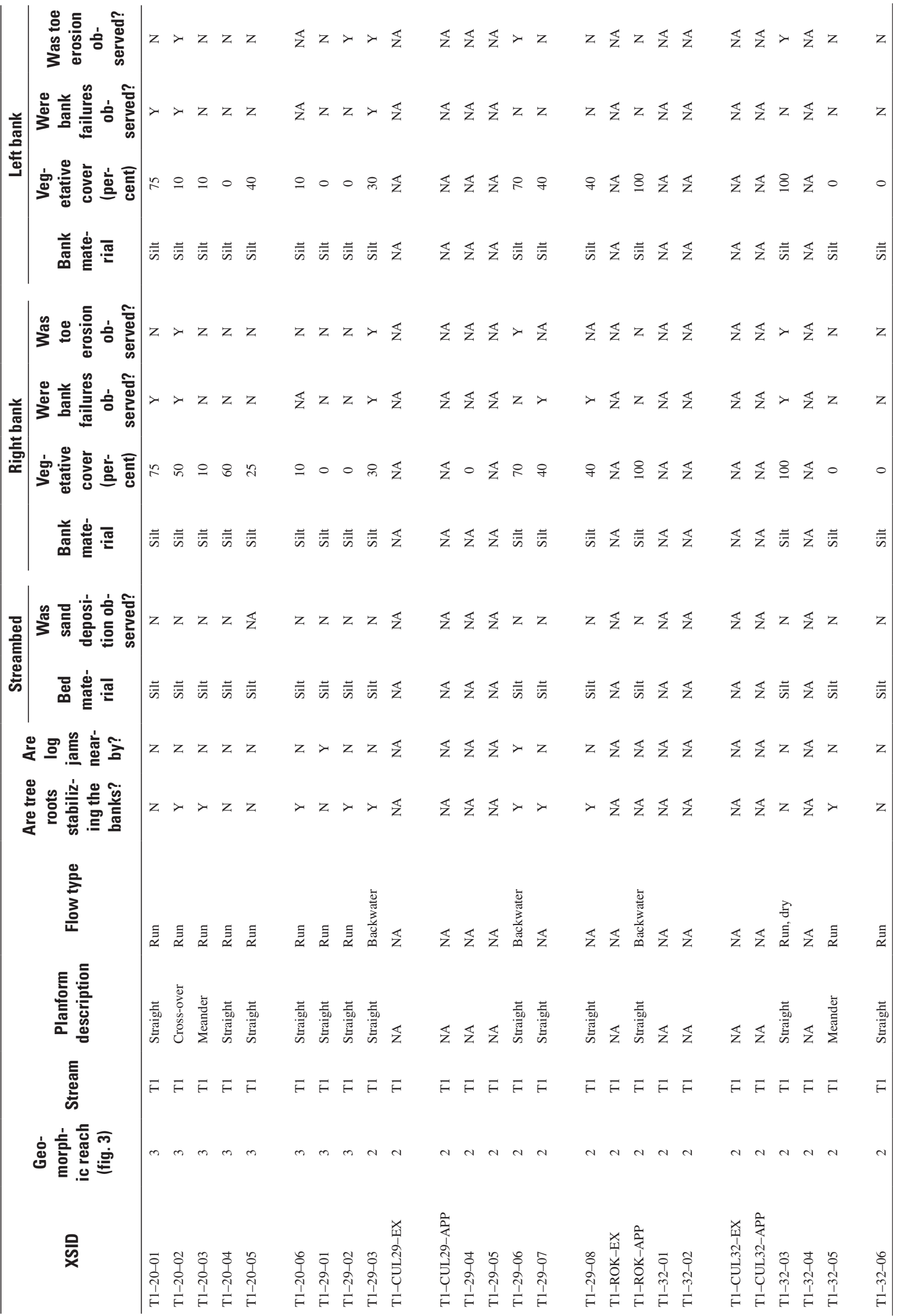


Appendix 3. Classification of channels in the Cardwell Branch study area.

[XSID, cross-section identifier; NA, not enough information to assess; C, Cardwell Branch; T1, unnamed tributary; W:D, width-to-depth ratio]

\begin{tabular}{|c|c|c|c|c|c|c|c|c|c|}
\hline \multirow[b]{2}{*}{ XSID } & \multirow[b]{2}{*}{$\begin{array}{l}\text { Geomor- } \\
\text { phic reach } \\
\text { (fig. 3) }\end{array}$} & \multirow[b]{2}{*}{ Stream } & \multirow[b]{2}{*}{$\begin{array}{c}\text { Stage of } \\
\text { channel } \\
\text { evolution }{ }^{1}\end{array}$} & \multicolumn{2}{|c|}{ Bank stability index² } & \multicolumn{4}{|c|}{ Form-based classification ${ }^{3}$} \\
\hline & & & & $\begin{array}{l}\text { Index } \\
\text { value }\end{array}$ & $\begin{array}{c}\text { Classifi- } \\
\text { cation }\end{array}$ & $\begin{array}{l}\text { Entrench- } \\
\text { ment ratio }\end{array}$ & W:D ratio & $\begin{array}{c}\text { Reach } \\
\text { sinuosity }\end{array}$ & $\begin{array}{c}\text { Reach } \\
\text { slope (foot } \\
\text { per foot) }\end{array}$ \\
\hline C-77-SB-APP & 5 & $\mathrm{C}$ & 4 & 15 & Unstable & 2.7 & 3.3 & 1.21 & 0.0028 \\
\hline $\mathrm{C}-23-01$ & 5 & $\mathrm{C}$ & 4 & 14 & Unstable & 28.5 & 3.6 & 1.21 & .0028 \\
\hline $\mathrm{C}-1 \mathrm{st}-\mathrm{EX}$ & 5 & $\mathrm{C}$ & 4 & 14 & Unstable & 1.4 & 6.7 & 1.21 & .0028 \\
\hline C-1st-APP & 5 & $\mathrm{C}$ & 4 & 13 & Unstable & 1.4 & 6.1 & 1.21 & .0028 \\
\hline $\mathrm{C}-22-57$ & 5 & $\mathrm{C}$ & 4 & 13 & Unstable & 1.4 & 6.3 & 1.21 & .0028 \\
\hline $\mathrm{C}-22-56$ & 5 & $\mathrm{C}$ & 4 & 13 & Unstable & 2.2 & 3.5 & 1.21 & .0028 \\
\hline $\mathrm{C}-22-53$ & 4 & $\mathrm{C}$ & 4 & 14 & Unstable & 14.1 & 3.4 & 2.20 & .0012 \\
\hline C-22-52 & 4 & $\mathrm{C}$ & 4 & 12 & Unstable & 1.1 & 14.3 & 2.20 & .0012 \\
\hline C-22-51 & 4 & $\mathrm{C}$ & 4 & 13 & Unstable & 1.3 & 9.2 & 2.20 & .0012 \\
\hline C-22-06 & 4 & $\mathrm{C}$ & 4 & 14 & Unstable & 3.9 & 4.1 & 2.20 & .0012 \\
\hline $\mathrm{C}-22-50$ & 4 & $\mathrm{C}$ & 4 & 13 & Unstable & 1.4 & 6.3 & 2.20 & .0012 \\
\hline C-22-05 & 4 & $\mathrm{C}$ & 4 & 13 & Unstable & 23.3 & 3.9 & 2.20 & .0012 \\
\hline C-22-04 & 4 & $\mathrm{C}$ & 4 & 13 & Unstable & 13.1 & 3.9 & 2.20 & .0012 \\
\hline C-22-03 & 4 & $\mathrm{C}$ & 4 & 12 & Unstable & 17.4 & 5.5 & 2.20 & .0012 \\
\hline $\mathrm{C}-21-02$ & 4 & $\mathrm{C}$ & 4 & 13 & Unstable & 1.6 & 6.3 & 2.20 & .0012 \\
\hline $\mathrm{C}-21-03$ & 4 & $\mathrm{C}$ & 4 & 11 & Unstable & 1.0 & 16.0 & 2.20 & .0012 \\
\hline C-21-04 & 4 & $\mathrm{C}$ & 4 & 12 & Unstable & 1.2 & 13.8 & 2.20 & .0012 \\
\hline $\mathrm{C}-21-05$ & 4 & $\mathrm{C}$ & NA & NA & NA & 1.3 & 9.7 & 2.20 & .0012 \\
\hline C-21-06 & 4 & $\mathrm{C}$ & NA & NA & NA & 1.1 & 11.3 & 2.20 & .0012 \\
\hline C-21-07 & 4 & $\mathrm{C}$ & 5 & 13 & Unstable & 2.2 & 4.1 & 2.20 & .0012 \\
\hline$C-21-55$ & 4 & $\mathrm{C}$ & 4 & 14 & Unstable & 1.5 & 5.7 & 2.20 & .0012 \\
\hline C-21-54 & 4 & $\mathrm{C}$ & 4 & 12 & Unstable & 1.4 & 4.9 & 2.20 & .0012 \\
\hline C-21-53-DS & 4 & $\mathrm{C}$ & 4 & 14 & Unstable & 1.1 & 5.6 & 2.20 & .0012 \\
\hline C-21-53-US & 4 & $\mathrm{C}$ & 4 & 13 & Unstable & 1.3 & 6.0 & 2.20 & .0012 \\
\hline$C-21-52$ & 4 & $\mathrm{C}$ & 4 & 11 & Unstable & 4.5 & 3.8 & 2.20 & .0012 \\
\hline C-21-51 & 4 & $\mathrm{C}$ & 4 & 12 & Unstable & 1.6 & 4.4 & 2.20 & .0012 \\
\hline C-21-50 & 1 & $\mathrm{C}$ & 4 & NA & NA & 1.5 & 3.5 & 1.50 & .0019 \\
\hline
\end{tabular}


Appendix 3. Classification of channels in the Cardwell Branch study area.-Continued

[XSID, cross-section identifier; NA, not enough information to assess; C, Cardwell Branch; T1, unnamed tributary; W:D, width-to-depth ratio]

\begin{tabular}{|c|c|c|c|c|c|c|c|c|c|}
\hline \multirow[b]{2}{*}{ XSID } & \multirow[b]{2}{*}{$\begin{array}{c}\text { Geomor- } \\
\text { phic reach } \\
\text { (fig. } 3 \text { ) }\end{array}$} & \multirow[b]{2}{*}{ Stream } & \multirow[b]{2}{*}{$\begin{array}{l}\text { Stage of } \\
\text { channel } \\
\text { evolution }\end{array}$} & \multicolumn{2}{|c|}{ Bank stability index ${ }^{2}$} & \multicolumn{4}{|c|}{ Form-based classification ${ }^{3}$} \\
\hline & & & & $\begin{array}{l}\text { Index } \\
\text { value }\end{array}$ & $\begin{array}{c}\text { Classifi- } \\
\text { cation }\end{array}$ & $\begin{array}{l}\text { Entrench- } \\
\text { ment ratio }\end{array}$ & W:D ratio & $\begin{array}{c}\text { Reach } \\
\text { sinuosity }\end{array}$ & $\begin{array}{c}\text { Reach } \\
\text { slope (foot } \\
\text { per foot) }\end{array}$ \\
\hline C-27TH-EX & 1 & $\mathrm{C}$ & 4 & NA & NA & 1.9 & 5.5 & 1.50 & 0.0019 \\
\hline C-27TH-APP & 1 & $\mathrm{C}$ & 4 & 10 & At risk & 5.1 & 5.0 & 1.50 & .0019 \\
\hline C-20-16 & 1 & $\mathrm{C}$ & 5 & 10 & At risk & 2.4 & 5.6 & 1.50 & .0019 \\
\hline C-20-15 & 1 & $\mathrm{C}$ & 4 & 12 & Unstable & 1.7 & 6.0 & 1.50 & .0019 \\
\hline C-20-14 & 1 & $\mathrm{C}$ & 5 & 10 & At risk & 2.1 & 4.9 & 1.50 & .0019 \\
\hline C-20-13 & 1 & $\mathrm{C}$ & 5 & 10 & At risk & 4.3 & 5.8 & 1.50 & .0019 \\
\hline C-20-09 & 1 & $\mathrm{C}$ & NA & 10 & At risk & 1.9 & 5.8 & 1.50 & .0019 \\
\hline C-20-08 & 1 & $\mathrm{C}$ & 4 & 12 & Unstable & 1.6 & 7.2 & 1.50 & .0019 \\
\hline $\mathrm{C}-20-07$ & 1 & $\mathrm{C}$ & 4 & 13 & Unstable & 3.6 & 3.2 & 1.50 & .0019 \\
\hline C-20-06 & 1 & $\mathrm{C}$ & 4 & 11 & Unstable & 2.5 & 4.7 & 1.50 & .0019 \\
\hline C-20-05 & 1 & $\mathrm{C}$ & NA & NA & NA & 2.8 & 5.3 & 1.50 & .0019 \\
\hline $\mathrm{C}-20-04$ & 1 & $\mathrm{C}$ & 4 & 10 & At risk & 1.6 & 8.1 & 1.50 & .0019 \\
\hline C-20-03 & 1 & $\mathrm{C}$ & 4 & 12 & Unstable & 1.8 & 6.9 & 1.50 & .0019 \\
\hline C-20-02 & 1 & $\mathrm{C}$ & NA & NA & NA & 1.3 & 9.7 & 1.50 & .0019 \\
\hline C-19-06 & 1 & $\mathrm{C}$ & 4 & 13 & Unstable & 12.8 & 4.4 & 1.50 & .0019 \\
\hline C-19-05 & 1 & $\mathrm{C}$ & 4 & 13 & Unstable & 3.3 & 6.3 & 1.50 & .0019 \\
\hline C-19-04 & 1 & $\mathrm{C}$ & NA & NA & NA & 9.6 & 4.7 & 1.50 & .0019 \\
\hline $\mathrm{T} 1-21-51$ & 3 & $\mathrm{~T} 1$ & 4 & 13 & Unstable & 2.3 & 4.6 & 1.48 & .0033 \\
\hline T1-CARDDR-APP & 3 & $\mathrm{~T} 1$ & 4 & 13 & Unstable & 3.9 & 3.5 & 1.48 & .0033 \\
\hline $\mathrm{T} 1-21-52$ & 3 & $\mathrm{~T} 1$ & 4 & 12 & Unstable & 1.4 & 6.7 & 1.48 & .0033 \\
\hline $\mathrm{T} 1-21-53$ & 3 & $\mathrm{~T} 1$ & 4 & NA & NA & 3.0 & 4.2 & 1.48 & .0033 \\
\hline $\mathrm{T} 1-21-06$ & 3 & $\mathrm{~T} 1$ & 4 & 11 & Unstable & 1.6 & 5.5 & 1.48 & .0033 \\
\hline $\mathrm{T} 1-21-54$ & 3 & $\mathrm{~T} 1$ & 4 & 13 & Unstable & 1.5 & 4.6 & 1.48 & .0033 \\
\hline $\mathrm{T} 1-21-05$ & 3 & $\mathrm{~T} 1$ & NA & NA & NA & 34.8 & 8.0 & 1.48 & .0033 \\
\hline $\mathrm{T} 1-21-04$ & 3 & $\mathrm{~T} 1$ & NA & 13 & Unstable & 22.9 & 4.0 & 1.48 & .0033 \\
\hline $\mathrm{T} 1-21-03$ & 3 & $\mathrm{~T} 1$ & 4 & 13 & Unstable & 3.2 & 9.4 & 1.48 & .0033 \\
\hline T1-21-02 & 3 & $\mathrm{~T} 1$ & 4 & 11 & Unstable & 1.9 & 10.2 & 1.48 & .0033 \\
\hline
\end{tabular}


Appendix 3. Classification of channels in the Cardwell Branch study area.-Continued

[XSID, cross-section identifier; NA, not enough information to assess; C, Cardwell Branch; T1, unnamed tributary; W:D, width-to-depth ratio]

\begin{tabular}{|c|c|c|c|c|c|c|c|c|c|}
\hline \multirow[b]{2}{*}{ XSID } & \multirow[b]{2}{*}{$\begin{array}{l}\text { Geomor- } \\
\text { phic reach } \\
\text { (fig. 3) }\end{array}$} & \multirow[b]{2}{*}{ Stream } & \multirow[b]{2}{*}{$\begin{array}{c}\text { Stage of } \\
\text { channel } \\
\text { evolution }{ }^{1}\end{array}$} & \multicolumn{2}{|c|}{ Bank stability index² } & \multicolumn{4}{|c|}{ Form-based classification ${ }^{3}$} \\
\hline & & & & $\begin{array}{l}\text { Index } \\
\text { value }\end{array}$ & $\begin{array}{c}\text { Classifi- } \\
\text { cation }\end{array}$ & $\begin{array}{l}\text { Entrench- } \\
\text { ment ratio }\end{array}$ & W:D ratio & $\begin{array}{c}\text { Reach } \\
\text { sinuosity }\end{array}$ & $\begin{array}{c}\text { Reach } \\
\text { slope (foot } \\
\text { per foot) }\end{array}$ \\
\hline T1-21-01 & 3 & $\mathrm{~T} 1$ & 4 & 11 & Unstable & 1.6 & 5.5 & 1.48 & 0.0033 \\
\hline T1-27TH-EX & 3 & $\mathrm{~T} 1$ & 4 & 10 & At risk & 5.7 & 3.2 & 1.48 & .0033 \\
\hline T1-20-02 & 3 & $\mathrm{~T} 1$ & 4 & 12 & Unstable & 1.6 & 4.7 & 1.48 & .0033 \\
\hline T1-20-03 & 3 & $\mathrm{~T} 1$ & 4 & 13 & Unstable & 6.2 & 4.2 & 1.48 & .0033 \\
\hline T1-20-04 & 3 & $\mathrm{~T} 1$ & 4 & 12 & Unstable & 1.3 & 5.3 & 1.48 & .0033 \\
\hline T1-20-05 & 3 & $\mathrm{~T} 1$ & 4 & 12 & Unstable & 18.9 & 2.9 & 1.48 & .0033 \\
\hline T1-29-02 & 3 & $\mathrm{~T} 1$ & 4 & 14 & Unstable & 1.5 & 7.8 & 1.48 & .0033 \\
\hline T1-29-03 & 2 & $\mathrm{~T} 1$ & 4 & 12 & Unstable & 1.2 & 7.1 & 1.31 & .0052 \\
\hline T1-CUL29-EX & 2 & $\mathrm{~T} 1$ & NA & NA & NA & 20.5 & 7.0 & 1.31 & .0052 \\
\hline T1-CUL29-APP & 2 & $\mathrm{~T} 1$ & NA & NA & NA & 12.4 & 9.7 & 1.31 & .0052 \\
\hline T1-29-04 & 2 & $\mathrm{~T} 1$ & NA & 11 & Unstable & 1.2 & 11.7 & 1.31 & .0052 \\
\hline T1-29-05 & 2 & $\mathrm{~T} 1$ & NA & NA & NA & 1.4 & 11.1 & 1.31 & .0052 \\
\hline T1-29-06 & 2 & $\mathrm{~T} 1$ & 4 & 9 & At risk & 1.3 & 10.8 & 1.31 & .0052 \\
\hline T1-29-07 & 2 & $\mathrm{~T} 1$ & 4 & 11 & Unstable & 41.8 & 4.6 & 1.31 & .0052 \\
\hline T1-CUL32-EX & 2 & $\mathrm{~T} 1$ & NA & NA & NA & 17.4 & 6.9 & 1.31 & .0052 \\
\hline T1-CUL32-APP & 2 & $\mathrm{~T} 1$ & NA & NA & NA & 1.6 & 4.6 & 1.31 & .0052 \\
\hline T1-32-03 & 2 & $\mathrm{~T} 1$ & 4 & 9 & At risk & 1.2 & 10.2 & 1.31 & .0052 \\
\hline T1-32-04 & 2 & $\mathrm{~T} 1$ & NA & NA & NA & 1.3 & 8.5 & 1.31 & .0052 \\
\hline T1-32-05 & 2 & $\mathrm{~T} 1$ & 4 & 11 & Unstable & 13.0 & 9.9 & 1.31 & .0052 \\
\hline T1-32-06 & 2 & $\mathrm{~T} 1$ & 4 & 11 & Unstable & 4.2 & 7.6 & 1.31 & .0052 \\
\hline
\end{tabular}

\footnotetext{
${ }^{1}$ From Simon (1989).
}

${ }^{2}$ From Fitzpatrick and others (1998).

${ }^{3}$ From Rosgen (1994). 
46 Assessment of Hydrology, Fluvial Geomorphology, and Stream Ecology in the Cardwell Branch Watershed, Nebraska

Appendix 4. Meander geometry measured at selected meanders in the Cardwell Branch study area.

[No identifiable meanders exist in reach 5; ID, identification; RC, radius of curvature]

\begin{tabular}{|c|c|c|c|c|c|c|}
\hline $\begin{array}{c}\text { Meander ID } \\
\text { (fig. 3) }\end{array}$ & $\begin{array}{l}\text { Geomorphic } \\
\text { reach (fig. 3) }\end{array}$ & $\begin{array}{c}\text { Meander wavelength } \\
\text { (feet) }\end{array}$ & $\begin{array}{c}\text { Belt width } \\
\text { (feet) }\end{array}$ & $\begin{array}{c}\text { RC of first bend } \\
\text { (feet) }\end{array}$ & $\begin{array}{c}\text { RC of second bend } \\
\text { (feet) }\end{array}$ & $\begin{array}{c}\text { Mean RC } \\
\text { (feet) }\end{array}$ \\
\hline $1-1$ & 1 & 280 & 91 & 28 & 35 & 32 \\
\hline $1-3$ & 1 & 310 & 120 & 45 & 44 & 45 \\
\hline $1-4$ & 1 & 200 & 63 & 27 & 30 & 29 \\
\hline $2-1$ & 2 & 870 & 200 & 115 & 85 & 100 \\
\hline $2-2$ & 2 & 1,130 & 260 & 100 & 100 & 100 \\
\hline $2-3$ & 2 & 940 & 380 & 75 & 150 & 113 \\
\hline $3-1$ & 3 & 480 & 140 & 50 & 55 & 53 \\
\hline $3-2$ & 3 & 470 & 170 & 52 & 28 & 40 \\
\hline $3-3$ & 3 & 430 & 190 & 32 & 35 & 34 \\
\hline $3-4$ & 3 & 240 & 62 & 18 & 13 & 16 \\
\hline $3-5$ & 3 & 390 & 110 & 25 & 38 & 32 \\
\hline $4-1$ & 4 & 570 & 210 & 43 & 55 & 49 \\
\hline $4-2$ & 4 & 910 & 410 & 50 & 55 & 53 \\
\hline $4-3$ & 4 & 850 & 210 & 86 & 95 & 91 \\
\hline
\end{tabular}


Appendix 5. Water-quality constituents in samples from Cardwell Branch (USGS station 404413096431401), Nebraska, 2003-04.

[National Water Information System parameter codes associated with each constituent given in parentheses; remark codes used in the table: E, estimated; <, less than; --, not measured; M, constituent was detected but not quantified; V, constituent may be affected by presumed contamination sources]

\begin{tabular}{|c|c|c|c|c|c|c|c|c|}
\hline $\begin{array}{c}\text { Sample } \\
\text { date } \\
\text { (month/day/ } \\
\text { year) }\end{array}$ & Time & $\begin{array}{c}\text { Discharge, } \\
\text { instantaneous } \\
\text { (cubic feet } \\
\text { per second) } \\
\text { (00061) }\end{array}$ & $\begin{array}{c}\text { Specific } \\
\text { conductance, } \\
\text { water, } \\
\text { unfiltered } \\
\text { (microsie- } \\
\text { mens per } \\
\text { centimeter } \\
\text { at } 25 \text { degrees } \\
\text { Celsius) } \\
\text { (00095) }\end{array}$ & $\begin{array}{l}\text { pH, water, } \\
\text { unfiltered, } \\
\text { field } \\
\text { (standard } \\
\text { units) } \\
\text { (00400) }\end{array}$ & $\begin{array}{c}\text { Temperature, } \\
\text { air } \\
\text { (degrees } \\
\text { Celsius) } \\
\text { (00020) }\end{array}$ & $\begin{array}{c}\text { Temperature, } \\
\text { water } \\
\text { (degrees } \\
\text { Celsius) } \\
\text { (00010) }\end{array}$ & $\begin{array}{c}\text { Barometric } \\
\text { pressure } \\
\text { (millimeters } \\
\text { of mercury) } \\
\text { (00025) }\end{array}$ & $\begin{array}{c}\text { Turbidity, water, } \\
\text { unfiltered, } \\
\text { broad band } \\
\text { light source } \\
\text { (400-680 } \\
\text { nanometers), } \\
\text { detectors at } \\
\text { multiple angles } \\
\text { including } 90 \\
\text { +30 degrees, } \\
\text { ratiometric } \\
\text { correction } \\
\text { (nephelometric } \\
\text { turbidity ratio } \\
\text { units) } \\
\text { (63676) }\end{array}$ \\
\hline $2 / 4 / 04$ & 9:00 & .01 & 780 & 7.7 & -6.4 & -.8 & 734 & 17 \\
\hline $3 / 1 / 04$ & 9:00 & .84 & 460 & 7.5 & -- & 1.6 & 713 & 65 \\
\hline $5 / 24 / 04$ & 11:00 & 8.2 & 277 & 6.5 & 23 & 18.3 & 725 & 1,600 \\
\hline $6 / 14 / 04$ & $13: 30$ & 6.8 & 288 & 7.8 & 31.7 & 21.7 & 726 & 1,300 \\
\hline $7 / 19 / 04$ & $9: 30$ & .84 & 423 & 7.7 & 29.5 & 22.2 & 723 & 140 \\
\hline $8 / 25 / 04$ & $9: 30$ & .1 & 576 & 7.8 & 25.5 & 21.1 & 722 & E25 \\
\hline $11 / 1 / 04$ & 10:00 & .73 & 675 & 7.8 & 13.7 & 11.9 & 721 & 68 \\
\hline $\begin{array}{c}\text { Sample } \\
\text { date } \\
\text { (month/day/ } \\
\text { year) }\end{array}$ & Time & $\begin{array}{c}\text { Dissolved } \\
\text { oxygen, water, } \\
\text { unfiltered } \\
\text { (milligrams } \\
\text { per liter) } \\
\text { (00300) }\end{array}$ & $\begin{array}{l}\text { Chemical } \\
\text { oxygen } \\
\text { demand, high } \\
\text { level, water, } \\
\text { unfiltered } \\
\text { (milligrams } \\
\text { per liter) } \\
\text { (00340) }\end{array}$ & $\begin{array}{l}\text { Biochemical } \\
\text { oxygen de- } \\
\text { mand, water, } \\
\text { unfiltered, } \\
5 \text { days at } \\
20 \text { degrees } \\
\text { Celsius } \\
\text { (milligrams } \\
\text { per liter) } \\
\text { (00310) }\end{array}$ & $\begin{array}{l}\text { Hardness, } \\
\text { water } \\
\text { (milligrams } \\
\text { per liter as } \\
\text { calcium } \\
\text { carbonate) } \\
\text { (00900) }\end{array}$ & $\begin{array}{c}\text { Noncarbon- } \\
\text { ate hardness, } \\
\text { water, filtered, } \\
\text { laboratory } \\
\text { (milligrams } \\
\text { per liter as } \\
\text { calcium } \\
\text { carbonate) } \\
\text { (00905) }\end{array}$ & $\begin{array}{c}\text { Alkalin- } \\
\text { ity, water, } \\
\text { filtered, fixed } \\
\text { endpoint } \\
\text { (pH 4.5) } \\
\text { titration, } \\
\text { laboratory } \\
\text { (milligrams } \\
\text { per liter as } \\
\text { calcium } \\
\text { carbonate) } \\
\text { (29801) }\end{array}$ & $\begin{array}{c}\text { Dissolved } \\
\text { solids } \\
\text { (milligrams per } \\
\text { liter) } \\
(70300)\end{array}$ \\
\hline $8 / 28 / 03$ & $9: 00$ & 2.4 & 30 & 2.6 & 230 & -- & 311 & 427 \\
\hline $12 / 15 / 03$ & $11: 00$ & 10.8 & 20 & 2 & 260 & -- & 323 & 461 \\
\hline $2 / 4 / 04$ & 9:00 & 10.9 & 10 & E1.8 & 300 & -- & 352 & 520 \\
\hline 3/1/04 & 9:00 & 10.3 & $<10$ & 3.7 & 160 & -- & 164 & 289 \\
\hline $5 / 24 / 04$ & $11: 00$ & 8.9 & 90 & 9.8 & 98 & 32 & 67 & 181 \\
\hline $6 / 14 / 04$ & $13: 30$ & 7.6 & $<10$ & 5.8 & 97 & 11 & 86 & 153 \\
\hline $7 / 19 / 04$ & $9: 30$ & 6.5 & 30 & 3.2 & 170 & 10 & 158 & 264 \\
\hline $8 / 25 / 04$ & $9: 30$ & 4.4 & 20 & 2.8 & 230 & -- & 249 & 332 \\
\hline $11 / 1 / 04$ & 10:00 & 6.7 & 30 & 4.9 & 250 & -- & 305 & 422 \\
\hline
\end{tabular}


Appendix 5. Water-quality constituents in samples from Cardwell Branch (USGS station 404413096431401), Nebraska, 2003-04.—Continued

[National Water Information System parameter codes associated with each constituent given in parentheses; remark codes used in the table: E, estimated; <, less than; --, not measured; $\mathrm{M}$, constituent was detected but not quantified; $\mathrm{V}$, constituent may be affected by presumed contamination sources]

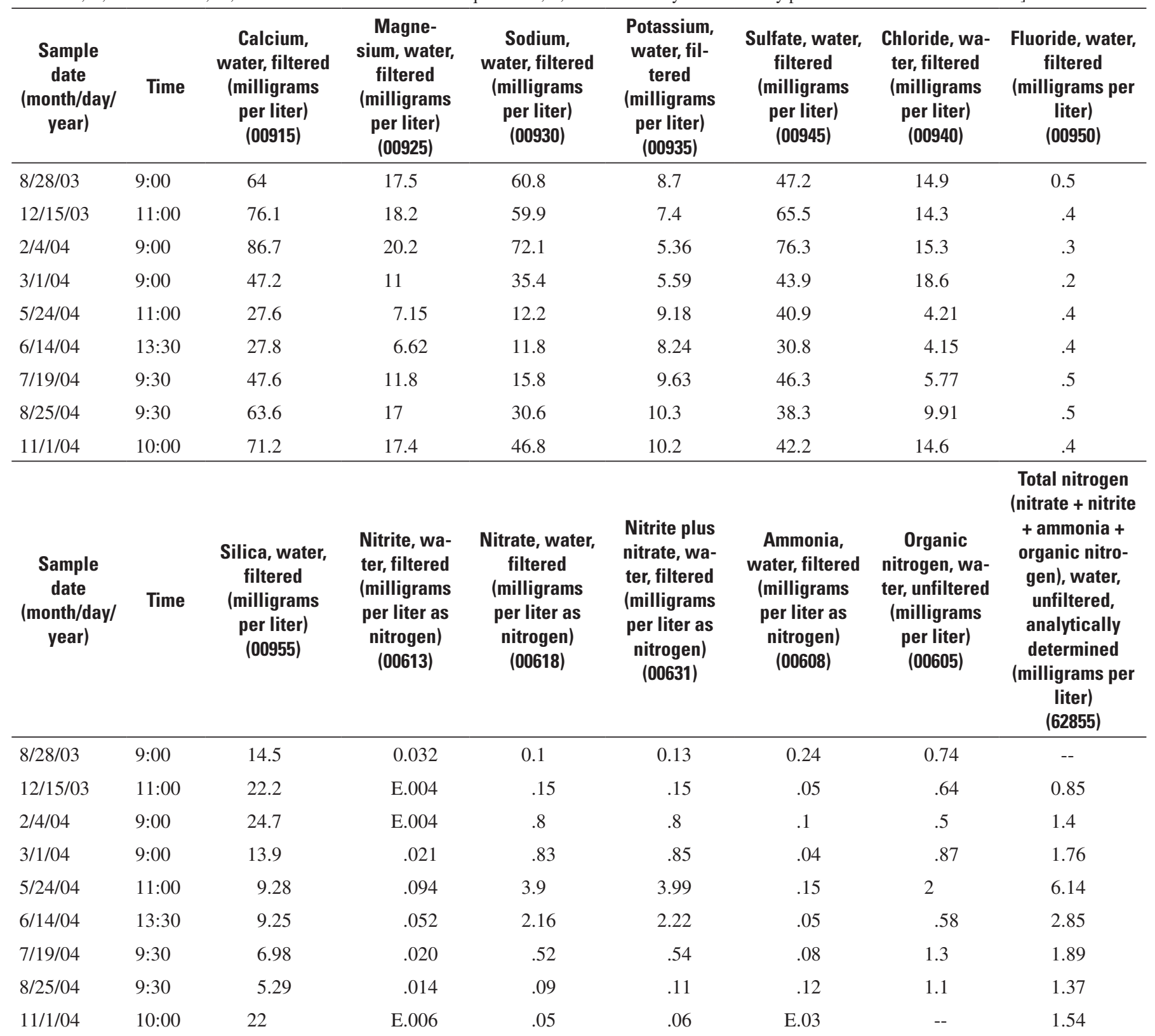


Appendix 5. Water-quality constituents in samples from Cardwell Branch (USGS station 404413096431401), Nebraska, 2003-04.—Continued

[National Water Information System parameter codes associated with each constituent given in parentheses; remark codes used in the table: E, estimated; < less than; --, not measured; M, constituent was detected but not quantified; V, constituent may be affected by presumed contamination sources]

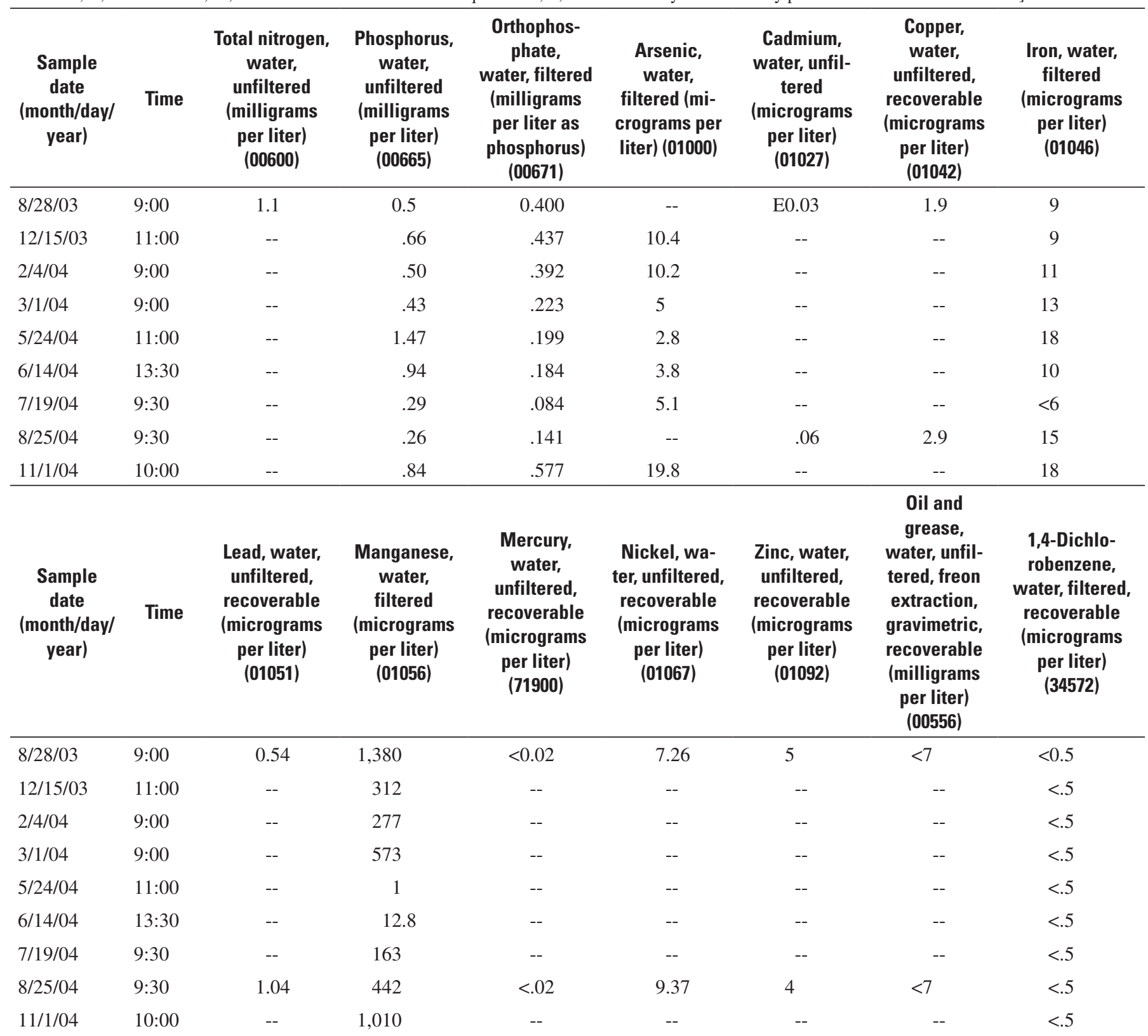


Appendix 5. Water-quality constituents in samples from Cardwell Branch (USGS station 404413096431401), Nebraska, 2003-04.—Continued

[National Water Information System parameter codes associated with each constituent given in parentheses; remark codes used in the table: E, estimated; <, less than; --, not measured; $\mathrm{M}$, constituent was detected but not quantified; $\mathrm{V}$, constituent may be affected by presumed contamination sources]

\begin{tabular}{|c|c|c|c|c|c|c|c|c|}
\hline $\begin{array}{c}\text { Sample } \\
\text { date } \\
\text { (month/day/ } \\
\text { year) }\end{array}$ & Time & $\begin{array}{l}\text { 1-Methyl- } \\
\text { naphthalene, } \\
\text { water, filtered, } \\
\text { recoverable } \\
\text { (micrograms } \\
\text { per liter) } \\
\text { (62054) }\end{array}$ & $\begin{array}{c}\text { 2,6-Diethyl- } \\
\text { aniline, wa- } \\
\text { ter, filtered } \\
\text { (0.7-micron } \\
\text { glass } \\
\text { fiber filter), } \\
\text { recoverable } \\
\text { (micrograms } \\
\text { per liter) } \\
\text { (82660) }\end{array}$ & $\begin{array}{c}\text { 2,6-Dimethyl- } \\
\text { naphthalene, } \\
\text { water, filtered, } \\
\text { recoverable } \\
\text { (micrograms } \\
\text { per liter) } \\
\text { (62055) }\end{array}$ & $\begin{array}{l}\text { 2-Chloro-4- } \\
\text { isopropylami- } \\
\text { no-6-amino- } \\
\text { s-triazine, } \\
\text { water, } \\
\text { filtered, re- } \\
\text { coverable } \\
\text { (micrograms } \\
\text { per liter) } \\
\text { (04040) }\end{array}$ & $\begin{array}{c}\text { 2-Methyl- } \\
\text { naphthalene, } \\
\text { water, filtered, } \\
\text { recoverable } \\
\text { (micrograms } \\
\text { per liter) } \\
\text { (62056) }\end{array}$ & $\begin{array}{c}\text { 3-beta-Co- } \\
\text { prostanol, } \\
\text { water, } \\
\text { filtered, } \\
\text { recoverable } \\
\text { (micrograms } \\
\text { per liter) } \\
\text { (62057) }\end{array}$ & $\begin{array}{l}\text { 3-Methyl-1H- } \\
\text { indole, water, } \\
\text { filtered, } \\
\text { recoverable } \\
\text { (micrograms } \\
\text { per liter) } \\
\text { (62058) }\end{array}$ \\
\hline $8 / 28 / 03$ & 9:00 & $<0.5$ & $<0.006$ & $<0.5$ & E0.020 & $<0.5$ & $<2$ & $<1$ \\
\hline $12 / 15 / 03$ & 11:00 & $<.5$ & $<.006$ & $<.5$ & E.006 & $<.5$ & $<2$ & $<1$ \\
\hline $2 / 4 / 04$ & 9:00 & M & $<.006$ & $<.5$ & E.008 & M & $<2$ & $<1$ \\
\hline $3 / 1 / 04$ & 9:00 & $<.5$ & $<.006$ & $<.5$ & E.062 & $<.5$ & $<2$ & $<1$ \\
\hline 7/19/04 & $9: 30$ & $<.5$ & $<.006$ & $<.5$ & E.721 & $<.5$ & $<2$ & $<1$ \\
\hline $8 / 25 / 04$ & $9: 30$ & $<.5$ & $<.006$ & $<.5$ & E.338 & $<.5$ & $<2$ & $<1$ \\
\hline $11 / 1 / 04$ & $10: 00$ & $<.5$ & $<.006$ & $<.5$ & E.056 & $<.5$ & $<2$ & M \\
\hline $\begin{array}{c}\text { Sample } \\
\text { date } \\
\text { (month/day/ } \\
\text { year) }\end{array}$ & Time & $\begin{array}{c}\text { 3-tert-Butyl- } \\
\text { 4-hydroxy- } \\
\text { anisole, } \\
\text { water, filtered, } \\
\text { recoverable } \\
\text { (micrograms } \\
\text { per liter) } \\
\text { (62059) }\end{array}$ & $\begin{array}{l}\text { 4-Cumylphe- } \\
\text { nol, water, } \\
\text { filtered, } \\
\text { recoverable } \\
\text { (micrograms } \\
\text { per liter) } \\
\text { (62060) }\end{array}$ & $\begin{array}{l}\text { 4-0ctylphenol, } \\
\text { water, filtered, } \\
\text { recoverable } \\
\text { (micrograms } \\
\text { per liter) } \\
\text { (62061) }\end{array}$ & $\begin{array}{l}\text { 4-Nonylphe- } \\
\text { nol, water, } \\
\text { filtered, } \\
\text { recoverable } \\
\text { (micrograms } \\
\text { per liter) } \\
\text { (62085) }\end{array}$ & $\begin{array}{c}\text { 4-tert-0c- } \\
\text { tylphenol, } \\
\text { water, filtered, } \\
\text { recoverable } \\
\text { (micrograms } \\
\text { per liter) } \\
\text { (62062) }\end{array}$ & $\begin{array}{c}\text { 5-Methyl- } \\
\text { 1H-benzotri- } \\
\text { azole, water, } \\
\text { filtered, } \\
\text { recoverable } \\
\text { (micrograms } \\
\text { per liter) } \\
\text { (62063) }\end{array}$ & $\begin{array}{l}\text { 9,10-Anthra- } \\
\text { quinone, } \\
\text { water, filtered, } \\
\text { recoverable } \\
\text { (micrograms } \\
\text { per liter) } \\
\text { (62066) }\end{array}$ \\
\hline $6 / 14 / 04$ & $13: 30$ & $<5$ & $<1$ & $<1$ & $<5$ & M & $<2$ & $<.5$ \\
\hline 7/19/04 & $9: 30$ & $<5$ & $<1$ & $<1$ & $<5$ & $<1$ & $<2$ & $<.5$ \\
\hline $8 / 25 / 04$ & $9: 30$ & $<5$ & $<1$ & $<1$ & E1 & $<1$ & $<2$ & $<.5$ \\
\hline $11 / 1 / 04$ & 10:00 & $<5$ & $<1$ & $<1$ & E3 & $<1$ & $<2$ & $<.5$ \\
\hline
\end{tabular}


Appendix 5. Water-quality constituents in samples from Cardwell Branch (USGS station 404413096431401), Nebraska, 2003-04.—Continued

[National Water Information System parameter codes associated with each constituent given in parentheses; remark codes used in the table: E, estimated; <, less than; --, not measured; M, constituent was detected but not quantified; V, constituent may be affected by presumed contamination sources]

\begin{tabular}{|c|c|c|c|c|c|c|c|c|}
\hline $\begin{array}{c}\text { Sample } \\
\text { date } \\
\text { (month/day/ } \\
\text { year) }\end{array}$ & Time & $\begin{array}{l}\text { 9H-Fluo- } \\
\text { rene, water, } \\
\text { unfiltered, } \\
\text { recoverable } \\
\text { (micrograms } \\
\text { per liter) } \\
\text { (34381) }\end{array}$ & $\begin{array}{c}\text { Acenaph- } \\
\text { thene, water, } \\
\text { unfiltered, } \\
\text { recoverable } \\
\text { (micrograms } \\
\text { per liter) } \\
\text { (34205) }\end{array}$ & $\begin{array}{c}\text { Acenaph- } \\
\text { thylene, } \\
\text { water, } \\
\text { unfiltered, } \\
\text { recoverable } \\
\text { (micrograms } \\
\text { per liter) } \\
\text { (34200) }\end{array}$ & $\begin{array}{l}\text { Acetochlor, } \\
\text { water, } \\
\text { filtered, } \\
\text { recoverable } \\
\text { (micrograms } \\
\text { per liter) } \\
\text { (49260) }\end{array}$ & $\begin{array}{c}\text { Acetophe- } \\
\text { none, water, } \\
\text { filtered, } \\
\text { recoverable } \\
\text { (micrograms } \\
\text { per liter) } \\
\text { (62064) }\end{array}$ & $\begin{array}{c}\text { Acetyl } \\
\text { hexamethyl } \\
\text { tetrahydro } \\
\text { naphtha- } \\
\text { lene, water, } \\
\text { filtered, } \\
\text { recoverable } \\
\text { (micrograms } \\
\text { per liter) } \\
\text { (62065) }\end{array}$ & $\begin{array}{l}\text { Alachlor, water, } \\
\text { filtered, } \\
\text { recoverable } \\
\text { (micrograms } \\
\text { per liter) } \\
\text { (46342) }\end{array}$ \\
\hline $8 / 28 / 03$ & 9:00 & $<2$ & $<2$ & $<2$ & $<0.006$ & $<0.5$ & $<0.5$ & $<0.004$ \\
\hline $12 / 15 / 03$ & 11:00 & -- & -- & -- & $<.006$ & $<.5$ & $<.5$ & $<.005$ \\
\hline $2 / 4 / 04$ & 9:00 & -- & -- & -- & $<.006$ & $<.5$ & M & $<.005$ \\
\hline $3 / 1 / 04$ & 9:00 & -- & -- & -- & $<.006$ & $<.5$ & $<.5$ & $<.005$ \\
\hline $7 / 19 / 04$ & $9: 30$ & -- & -- & -- & .009 & $<.5$ & $<.5$ & $<.005$ \\
\hline $8 / 25 / 04$ & $9: 30$ & $<2$ & M & $<2$ & $<.006$ & V.1 & $<.5$ & $<.005$ \\
\hline $11 / 1 / 04$ & $10: 00$ & -- & -- & -- & $<.006$ & $<.5$ & $<.5$ & $<.005$ \\
\hline $\begin{array}{c}\text { Sample } \\
\text { date } \\
\text { (month/day/ } \\
\text { year) }\end{array}$ & Time & $\begin{array}{c}\text { alpha-HCH, } \\
\text { water, filtered, } \\
\text { recoverable } \\
\text { (micrograms } \\
\text { per liter) } \\
\text { (34253) }\end{array}$ & $\begin{array}{l}\text { Anthracene, } \\
\text { water, } \\
\text { filtered, } \\
\text { recoverable } \\
\text { (micrograms } \\
\text { per liter) } \\
\text { (34221) }\end{array}$ & $\begin{array}{c}\text { Anthra- } \\
\text { cene, water, } \\
\text { unfiltered, } \\
\text { recoverable } \\
\text { (micrograms } \\
\text { per liter) } \\
\text { (34220) }\end{array}$ & $\begin{array}{l}\text { Atrazine, wa- } \\
\text { ter, filtered, } \\
\text { recoverable } \\
\text { (micrograms } \\
\text { per liter) } \\
\text { (39632) }\end{array}$ & $\begin{array}{l}\text { Azinphos- } \\
\text { methyl, water, } \\
\text { filtered } \\
\text { (0.7-micron } \\
\text { glass fiber } \\
\text { filter), } \\
\text { recoverable } \\
\text { (micrograms } \\
\text { per liter) } \\
\text { (82686) }\end{array}$ & $\begin{array}{c}\text { Benflura- } \\
\text { lin, water, } \\
\text { filtered } \\
\text { (0.7-micron } \\
\text { glass fiber } \\
\text { filter), recov- } \\
\text { erable } \\
\text { (micrograms } \\
\text { per liter) } \\
\text { (82673) }\end{array}$ & $\begin{array}{c}\text { Benzo[a]- } \\
\text { anthracene, } \\
\text { water, } \\
\text { unfiltered, } \\
\text { recoverable } \\
\text { (micrograms } \\
\text { per liter) } \\
\text { (34526) }\end{array}$ \\
\hline $5 / 24 / 04$ & 11:00 & $<.005$ & $<.5$ & -- & 11.8 & $<.050$ & $<.010$ & -- \\
\hline $6 / 14 / 04$ & $13: 30$ & $<.005$ & $<.5$ & -- & 13.3 & $<.050$ & $<.010$ & -- \\
\hline 7/19/04 & $9: 30$ & $<.005$ & $<.5$ & -- & 4.59 & $<.050$ & $<.010$ & -- \\
\hline $8 / 25 / 04$ & $9: 30$ & $<.005$ & $<.5$ & $<2$ & 1.3 & $<.050$ & $<.010$ & $<2$ \\
\hline $11 / 1 / 04$ & 10:00 & $<.005$ & $<.5$ & -- & .156 & $<.050$ & $<.010$ & -- \\
\hline
\end{tabular}


Appendix 5. Water-quality constituents in samples from Cardwell Branch (USGS station 404413096431401), Nebraska, 2003-04.—Continued

[National Water Information System parameter codes associated with each constituent given in parentheses; remark codes used in the table: E, estimated; <, less than; --, not measured; $\mathrm{M}$, constituent was detected but not quantified; $\mathrm{V}$, constituent may be affected by presumed contamination sources]

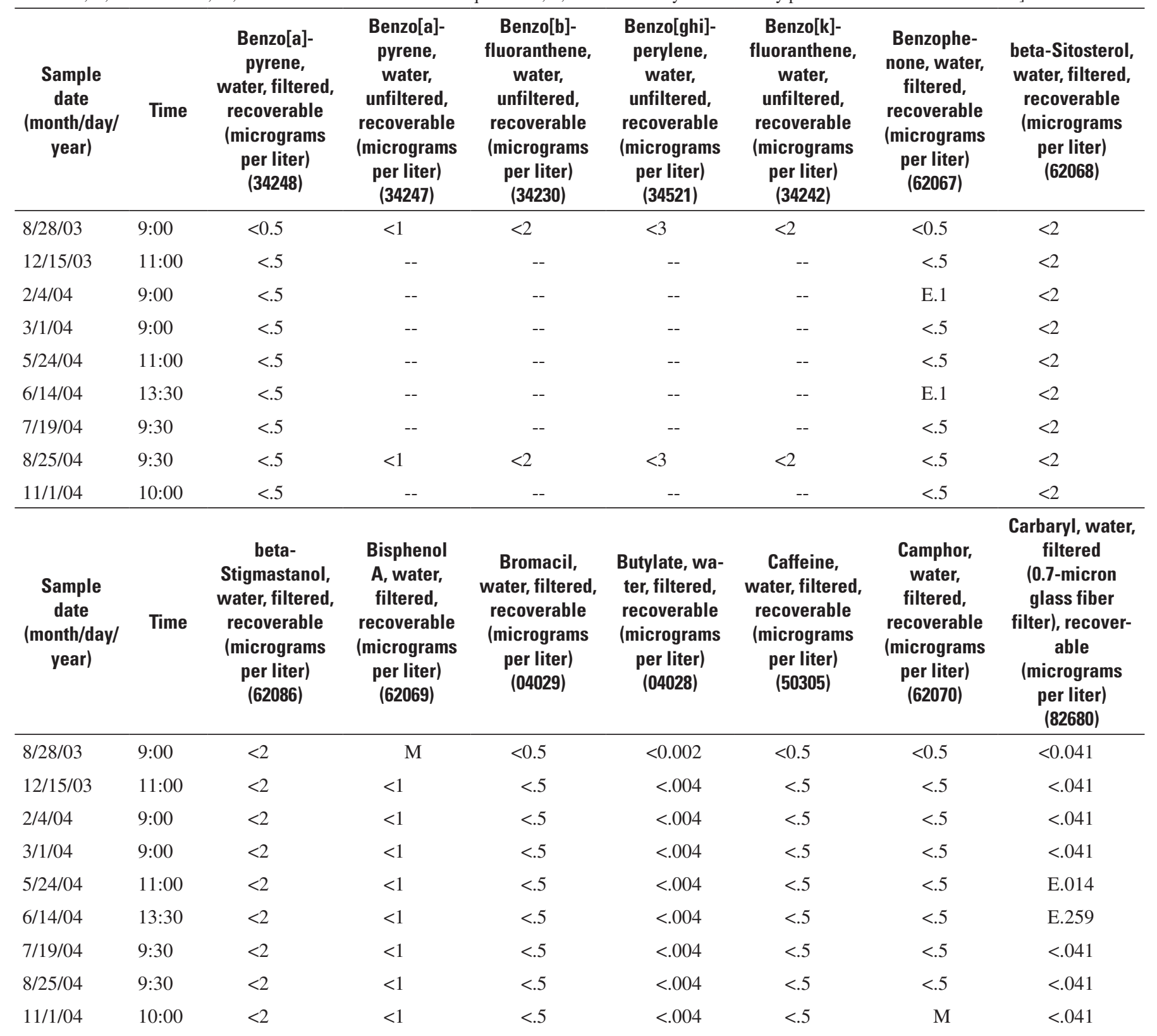


Appendix 5. Water-quality constituents in samples from Cardwell Branch (USGS station 404413096431401), Nebraska, 2003-04.—Continued

[National Water Information System parameter codes associated with each constituent given in parentheses; remark codes used in the table: E, estimated; <, less than; --, not measured; M, constituent was detected but not quantified; $\mathrm{V}$, constituent may be affected by presumed contamination sources]

\begin{tabular}{|c|c|c|c|c|c|c|c|c|}
\hline $\begin{array}{c}\text { Sample } \\
\text { date } \\
\text { (month/day/ } \\
\text { year) }\end{array}$ & Time & $\begin{array}{l}\text { Carbazole, } \\
\text { water, filtered, } \\
\text { recoverable } \\
\text { (micrograms } \\
\text { per liter) } \\
\text { (62071) }\end{array}$ & $\begin{array}{c}\text { Carbofu- } \\
\text { ran, water, } \\
\text { filtered } \\
\text { (0.7-micron } \\
\text { glass } \\
\text { fiber filter), } \\
\text { recoverable } \\
\text { (micrograms } \\
\text { per liter) } \\
\text { (82674) }\end{array}$ & $\begin{array}{l}\text { Chlorpyrifos, } \\
\text { water, filtered, } \\
\text { recoverable } \\
\text { (micrograms } \\
\text { per liter) } \\
\text { (38933) }\end{array}$ & $\begin{array}{c}\text { Choles- } \\
\text { terol, water, } \\
\text { filtered, } \\
\text { recoverable } \\
\text { (micrograms } \\
\text { per liter) } \\
\text { (62072) }\end{array}$ & $\begin{array}{c}\text { Chrysene, } \\
\text { water, } \\
\text { unfiltered, } \\
\text { recoverable } \\
\text { (micrograms } \\
\text { per liter) } \\
\text { (34320) }\end{array}$ & $\begin{array}{c}\text { cis-Perme- } \\
\text { thrin, water, } \\
\text { filtered } \\
\text { (0.7-micron } \\
\text { glass } \\
\text { fiber filter), } \\
\text { recoverable } \\
\text { (micrograms } \\
\text { per liter) } \\
\text { (82687) }\end{array}$ & $\begin{array}{c}\text { Cotinine, water, } \\
\text { filtered, recov- } \\
\text { erable } \\
\text { (micrograms } \\
\text { per liter) } \\
\text { (62005) }\end{array}$ \\
\hline $8 / 28 / 03$ & 9:00 & $<0.5$ & $<0.020$ & $<0.005$ & $<2$ & $<3$ & $<0.006$ & $<1.00$ \\
\hline $12 / 15 / 03$ & 11:00 & $<.5$ & $<.020$ & $<.005$ & $<2$ & -- & $<.006$ & $<1.00$ \\
\hline $2 / 4 / 04$ & 9:00 & M & $<.020$ & $<.005$ & $<2$ & -- & $<.006$ & $<1.00$ \\
\hline 7/19/04 & $9: 30$ & $<.5$ & $<.020$ & $<.005$ & E1 & -- & $<.006$ & $<1.00$ \\
\hline $8 / 25 / 04$ & $9: 30$ & $<.5$ & $<.020$ & $<.005$ & $<2$ & $<3$ & $<.006$ & $<1.00$ \\
\hline $11 / 1 / 04$ & 10:00 & $<.5$ & $<.020$ & $<.005$ & $<2$ & -- & $<.006$ & $<1.00$ \\
\hline $\begin{array}{c}\text { Sample } \\
\text { date } \\
\text { (month/day/ } \\
\text { year) }\end{array}$ & Time & $\begin{array}{c}\text { Cyanazine, } \\
\text { water, filtered, } \\
\text { recoverable } \\
\text { (micrograms } \\
\text { per liter) } \\
\text { (04041) }\end{array}$ & $\begin{array}{c}\text { DCPA, water, } \\
\text { filtered } \\
\text { (0.7-mi- } \\
\text { cron glass } \\
\text { fiber filter), } \\
\text { recoverable } \\
\text { (micrograms } \\
\text { per liter) } \\
\text { (82682) }\end{array}$ & $\begin{array}{l}\text { DEET, water, } \\
\text { filtered, } \\
\text { recoverable } \\
\text { (micrograms } \\
\text { per liter) } \\
\text { (62082) }\end{array}$ & $\begin{array}{c}\text { Desulfinyl } \\
\text { fipronil, } \\
\text { water, } \\
\text { filtered, } \\
\text { recoverable } \\
\text { (micrograms } \\
\text { per liter) } \\
\text { (62170) }\end{array}$ & $\begin{array}{c}\text { Diazinon, } \\
\text { water, filtered, } \\
\text { recoverable } \\
\text { (micrograms } \\
\text { per liter) } \\
\text { (39572) }\end{array}$ & $\begin{array}{c}\text { Dibenzo[a,h] } \\
\text { anthracene, } \\
\text { water, } \\
\text { unfiltered, } \\
\text { recoverable } \\
\text { (micrograms } \\
\text { per liter) } \\
\text { (34556) }\end{array}$ & $\begin{array}{l}\text { Dieldrin, water, } \\
\text { filtered, } \\
\text { recoverable } \\
\text { (micrograms } \\
\text { per liter) } \\
\text { (39381) }\end{array}$ \\
\hline $5 / 24 / 04$ & 11:00 & $<.018$ & $<.003$ & V.1 & $<.012$ & $<.006$ & -- & $<.009$ \\
\hline $6 / 14 / 04$ & $13: 30$ & $<.018$ & $<.003$ & V.1 & $<.012$ & $<.005$ & -- & $<.009$ \\
\hline $7 / 19 / 04$ & $9: 30$ & $<.018$ & $<.003$ & V.1 & $<.012$ & $<.005$ & -- & $<.009$ \\
\hline $8 / 25 / 04$ & $9: 30$ & $<.018$ & $<.003$ & V.1 & $<.012$ & $<.005$ & $<3$ & $<.009$ \\
\hline $11 / 1 / 04$ & $10: 00$ & $<.018$ & $<.003$ & E.2 & $<.012$ & $<.005$ & -- & $<.009$ \\
\hline
\end{tabular}


Appendix 5. Water-quality constituents in samples from Cardwell Branch (USGS station 404413096431401), Nebraska, 2003-04.—Continued

[National Water Information System parameter codes associated with each constituent given in parentheses; remark codes used in the table: E, estimated; <, less than; --, not measured; M, constituent was detected but not quantified; V, constituent may be affected by presumed contamination sources]

\begin{tabular}{|c|c|c|c|c|c|c|c|c|}
\hline $\begin{array}{c}\text { Sample } \\
\text { date } \\
\text { (month/day/ } \\
\text { year) }\end{array}$ & Time & $\begin{array}{l}\text { Diethoxyno- } \\
\text { nylphenol, } \\
\text { water, filtered, } \\
\text { recoverable } \\
\text { (micrograms } \\
\text { per liter) } \\
\text { (62083) }\end{array}$ & $\begin{array}{c}\text { Diethoxyoc- } \\
\text { tylphenol, } \\
\text { water, } \\
\text { filtered, } \\
\text { recoverable } \\
\text { (micrograms } \\
\text { per liter) } \\
\text { (61705) }\end{array}$ & $\begin{array}{c}\text { Disulfoton, } \\
\text { water, filtered } \\
\text { (0.7-micron } \\
\text { glass fiber } \\
\text { filter), } \\
\text { recoverable } \\
\text { (micrograms } \\
\text { per liter) } \\
\text { (82677) }\end{array}$ & $\begin{array}{c}\text { D-Limo- } \\
\text { nene, water, } \\
\text { filtered, } \\
\text { recoverable } \\
\text { (micrograms } \\
\text { per liter) } \\
\text { (62073) }\end{array}$ & $\begin{array}{c}\text { EPTC, water, } \\
\text { filtered } \\
\text { (0.7-micron } \\
\text { glass fiber } \\
\text { filter), } \\
\text { recoverable } \\
\text { (micrograms } \\
\text { per liter) } \\
\text { (82668) }\end{array}$ & $\begin{array}{l}\text { Ethalflura- } \\
\text { lin, water, } \\
\text { filtered } \\
\text { (0.7-micron } \\
\text { glass } \\
\text { fiber filter), } \\
\text { recoverable } \\
\text { (micrograms } \\
\text { per liter) } \\
\text { (82663) }\end{array}$ & $\begin{array}{c}\text { Ethoprop, water, } \\
\text { filtered } \\
\text { (0.7-micron } \\
\text { glass fiber } \\
\text { filter), } \\
\text { recoverable } \\
\text { (micrograms } \\
\text { per liter) } \\
\text { (82672) }\end{array}$ \\
\hline $8 / 28 / 03$ & 9:00 & $<5$ & $<1$ & $<0.02$ & E0.1 & $<0.002$ & $<0.009$ & $<0.005$ \\
\hline $12 / 15 / 03$ & $11: 00$ & $<5$ & $<1$ & $<.02$ & $<.5$ & $<.004$ & $<.009$ & $<.005$ \\
\hline $2 / 4 / 04$ & 9:00 & $<5$ & $<1$ & $<.02$ & $<.5$ & $<.004$ & $<.009$ & $<.005$ \\
\hline $3 / 1 / 04$ & 9:00 & $<5$ & $<1$ & $<.02$ & $<.5$ & $<.004$ & $<.009$ & $<.005$ \\
\hline $8 / 25 / 04$ & $9: 30$ & $<5$ & $<1$ & $<.02$ & $<.5$ & $<.004$ & $<.009$ & $<.005$ \\
\hline $11 / 1 / 04$ & 10:00 & $<5$ & $<1$ & $<.02$ & $<.5$ & $<.004$ & $<.009$ & $<.005$ \\
\hline $\begin{array}{c}\text { Sample } \\
\text { date } \\
\text { (month/day/ } \\
\text { year) }\end{array}$ & Time & $\begin{array}{c}\text { Ethoxyoc- } \\
\text { tylphenol, } \\
\text { water, filtered, } \\
\text { recoverable } \\
\text { (micrograms } \\
\text { per liter) } \\
\text { (61706) }\end{array}$ & $\begin{array}{c}\text { Desulfi- } \\
\text { nylfipronil } \\
\text { amide, water, } \\
\text { filtered, } \\
\text { recoverable } \\
\text { (micrograms } \\
\text { per liter) } \\
\text { (62169) }\end{array}$ & $\begin{array}{c}\text { Fipronil } \\
\text { sulfide, } \\
\text { water, filtered, } \\
\text { recoverable } \\
\text { (micrograms } \\
\text { per liter) } \\
\text { (62167) }\end{array}$ & $\begin{array}{c}\text { Fipronil } \\
\text { sulfone, } \\
\text { water, } \\
\text { filtered, } \\
\text { recoverable } \\
\text { (micrograms } \\
\text { per liter) } \\
\text { (62168) } \\
\end{array}$ & $\begin{array}{c}\text { Fipronil, } \\
\text { water, filtered, } \\
\text { recoverable } \\
\text { (micrograms } \\
\text { per liter) } \\
\text { (62166) }\end{array}$ & $\begin{array}{c}\text { Fluoran- } \\
\text { thene, } \\
\text { water, } \\
\text { filtered, } \\
\text { recoverable } \\
\text { (micrograms } \\
\text { per liter) } \\
\text { (34377) } \\
\end{array}$ & $\begin{array}{l}\text { Fluoranthene, } \\
\text { water, } \\
\text { unfiltered, } \\
\text { recoverable } \\
\text { (micrograms } \\
\text { per liter) } \\
\text { (34376) }\end{array}$ \\
\hline $6 / 14 / 04$ & $13: 30$ & $<1$ & $<.029$ & $<.013$ & $<.024$ & $<.016$ & $<.5$ & -- \\
\hline $7 / 19 / 04$ & $9: 30$ & $<1$ & $<.029$ & $<.013$ & $<.024$ & $<.016$ & $<.5$ & -- \\
\hline $8 / 25 / 04$ & $9: 30$ & $<1$ & $<.029$ & $<.013$ & $<.024$ & $<.016$ & $<.5$ & $<2$ \\
\hline $11 / 1 / 04$ & 10:00 & $<1$ & $<.029$ & $<.013$ & $<.024$ & $<.016$ & $<.5$ & -- \\
\hline
\end{tabular}


Appendix 5. Water-quality constituents in samples from Cardwell Branch (USGS station 404413096431401), Nebraska, 2003-04.—Continued

[National Water Information System parameter codes associated with each constituent given in parentheses; remark codes used in the table: E, estimated; <, less than; --, not measured; M, constituent was detected but not quantified; $\mathrm{V}$, constituent may be affected by presumed contamination sources]

\begin{tabular}{|c|c|c|c|c|c|c|c|c|}
\hline $\begin{array}{c}\text { Sample } \\
\text { date } \\
\text { (month/day/ } \\
\text { year) }\end{array}$ & Time & $\begin{array}{c}\text { Fonofos, } \\
\text { water, filtered, } \\
\text { recoverable } \\
\text { (micrograms } \\
\text { per liter) } \\
\text { (04095) }\end{array}$ & $\begin{array}{c}\text { Hexahydro- } \\
\text { hexamethyl } \\
\text { cyclopenta- } \\
\text { benzopyran, } \\
\text { water, } \\
\text { filtered, } \\
\text { recoverable } \\
\text { (micrograms } \\
\text { per liter) } \\
\text { (62075) }\end{array}$ & $\begin{array}{c}\text { Indeno[1,2,3- } \\
\text { cd]pyrene, } \\
\text { water, } \\
\text { unfiltered, } \\
\text { recoverable } \\
\text { (micrograms } \\
\text { per liter) } \\
\text { (34403) }\end{array}$ & $\begin{array}{c}\text { Indole, water, } \\
\text { filtered, } \\
\text { recoverable } \\
\text { (micrograms } \\
\text { per liter) } \\
\text { (62076) }\end{array}$ & $\begin{array}{l}\text { Isoborneol, } \\
\text { water, filtered, } \\
\text { recoverable } \\
\text { (micrograms } \\
\text { per liter) } \\
\text { (62077) }\end{array}$ & $\begin{array}{l}\text { Isophorone, } \\
\text { water, } \\
\text { filtered, } \\
\text { recoverable } \\
\text { (micrograms } \\
\text { per liter) } \\
\text { (34409) }\end{array}$ & $\begin{array}{l}\text { Isopropylben- } \\
\text { zene, water, } \\
\text { filtered, } \\
\text { recoverable } \\
\text { (micrograms } \\
\text { per liter) } \\
\text { (62078) }\end{array}$ \\
\hline $8 / 28 / 03$ & $9: 00$ & $<0.003$ & $<0.5$ & $<3$ & $<0.5$ & $<0.5$ & $<0.5$ & $<0.5$ \\
\hline $12 / 15 / 03$ & 11:00 & $<.003$ & $<.5$ & -- & $<.5$ & $<.5$ & $<.5$ & $<.5$ \\
\hline $2 / 4 / 04$ & 9:00 & $<.003$ & E.1 & -- & $<.5$ & $<.5$ & $<.5$ & $<.5$ \\
\hline $7 / 19 / 04$ & $9: 30$ & $<.003$ & $<.5$ & -- & $<.5$ & $<.5$ & $<.5$ & $<.5$ \\
\hline $8 / 25 / 04$ & $9: 30$ & $<.003$ & $<.5$ & $<3$ & $<.5$ & $<.5$ & $<.5$ & $<.5$ \\
\hline $11 / 1 / 04$ & $10: 00$ & $<.003$ & $<.5$ & -- & M & $<.5$ & $\mathrm{M}$ & $<.5$ \\
\hline $\begin{array}{c}\text { Sample } \\
\text { date } \\
\text { (month/day/ } \\
\text { year) }\end{array}$ & Time & $\begin{array}{l}\text { Isoquinoline, } \\
\text { water, filtered, } \\
\text { recoverable } \\
\text { (micrograms } \\
\text { per liter) } \\
\text { (62079) }\end{array}$ & $\begin{array}{c}\text { Lindane, } \\
\text { water, } \\
\text { filtered, } \\
\text { recoverable } \\
\text { (micrograms } \\
\text { per liter) } \\
\text { (39341) }\end{array}$ & $\begin{array}{c}\text { Linuron, } \\
\text { water, filtered } \\
\text { (0.7-micron } \\
\text { glass fiber } \\
\text { filter), } \\
\text { recoverable } \\
\text { (micrograms } \\
\text { per liter) } \\
\text { (82666) }\end{array}$ & $\begin{array}{c}\text { Mala- } \\
\text { thion, water, } \\
\text { filtered, } \\
\text { recoverable } \\
\text { (micrograms } \\
\text { per liter) } \\
\text { (39532) }\end{array}$ & $\begin{array}{l}\text { Menthol, } \\
\text { water, filtered, } \\
\text { recoverable } \\
\text { (micrograms } \\
\text { per liter) } \\
\text { (62080) }\end{array}$ & $\begin{array}{l}\text { Metalaxyl, } \\
\text { water, } \\
\text { filtered, } \\
\text { recoverable } \\
\text { (micrograms } \\
\text { per liter) } \\
\text { (50359) }\end{array}$ & $\begin{array}{c}\text { Methyl } \\
\text { parathion, } \\
\text { water, filtered } \\
\text { (0.7-micron } \\
\text { glass fiber } \\
\text { filter), } \\
\text { recoverable } \\
\text { (micrograms } \\
\text { per liter) } \\
\text { (82667) }\end{array}$ \\
\hline $3 / 1 / 04$ & 9:00 & $<.5$ & $<.004$ & $<.035$ & $<.027$ & $<.5$ & $<.5$ & $<.015$ \\
\hline $5 / 24 / 04$ & $11: 00$ & $<.5$ & $<.004$ & $<.035$ & $<.027$ & $<.5$ & $<.5$ & $<.015$ \\
\hline $6 / 14 / 04$ & $13: 30$ & $<.5$ & $<.004$ & $<.035$ & $<.027$ & E.1 & $<.5$ & $<.015$ \\
\hline $7 / 19 / 04$ & $9: 30$ & $<.5$ & $<.004$ & $<.035$ & $<.027$ & $<.5$ & $<.5$ & $<.015$ \\
\hline $8 / 25 / 04$ & $9: 30$ & $<.5$ & $<.004$ & $<.035$ & $<.027$ & $<.5$ & $<.5$ & $<.015$ \\
\hline $11 / 1 / 04$ & 10:00 & $<.5$ & $<.004$ & $<.035$ & $<.027$ & $<.5$ & $<.5$ & $<.015$ \\
\hline
\end{tabular}


Appendix 5. Water-quality constituents in samples from Cardwell Branch (USGS station 404413096431401), Nebraska, 2003-04.—Continued

[National Water Information System parameter codes associated with each constituent given in parentheses; remark codes used in the table: E, estimated; <, less than; --, not measured; $\mathrm{M}$, constituent was detected but not quantified; $\mathrm{V}$, constituent may be affected by presumed contamination sources]

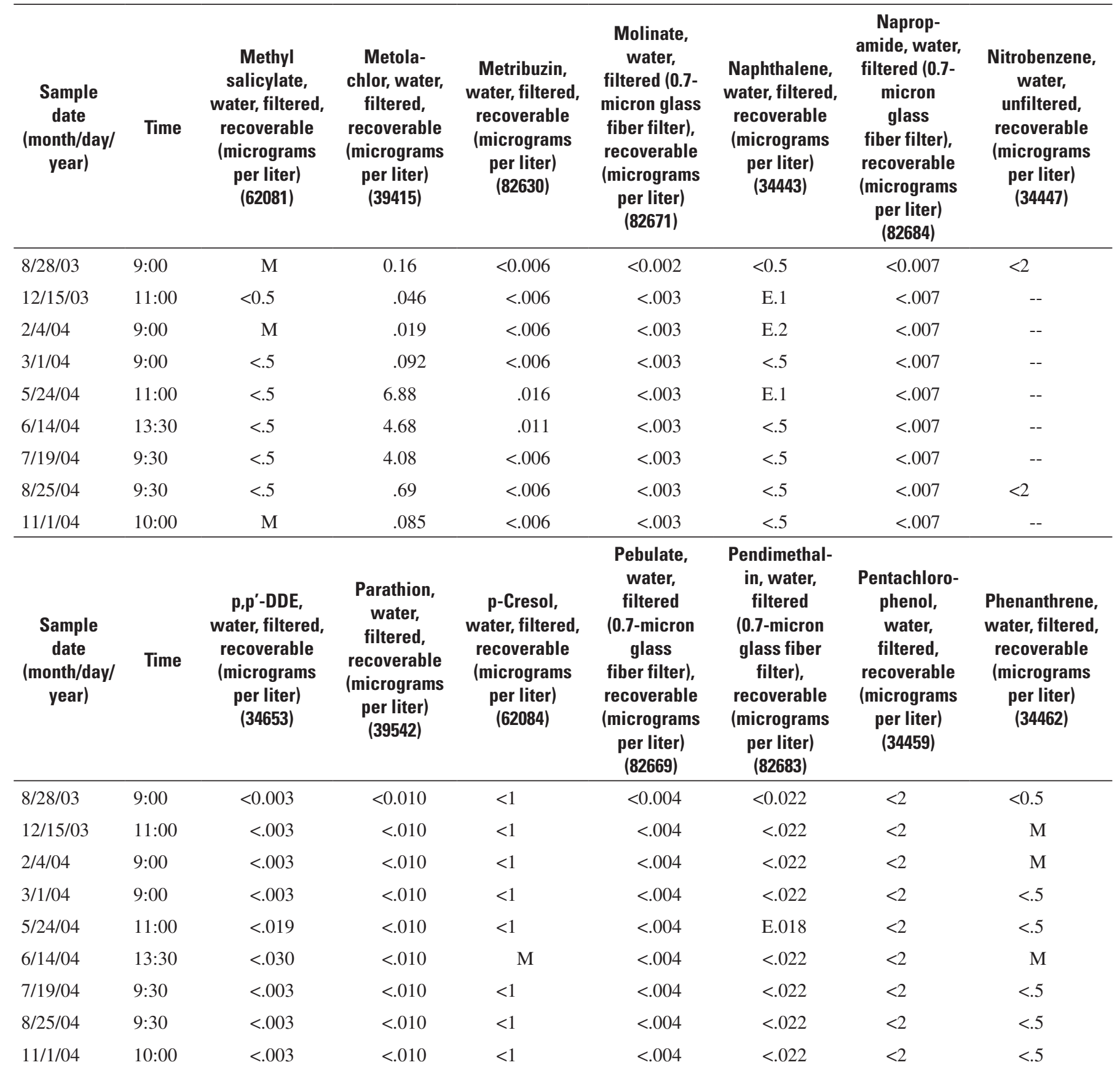


Appendix 5. Water-quality constituents in samples from Cardwell Branch (USGS station 404413096431401), Nebraska, 2003-04.—Continued

[National Water Information System parameter codes associated with each constituent given in parentheses; remark codes used in the table: E, estimated; <, less than; --, not measured; M, constituent was detected but not quantified; V, constituent may be affected by presumed contamination sources]

\begin{tabular}{|c|c|c|c|c|c|c|c|c|}
\hline $\begin{array}{c}\text { Sample } \\
\text { date } \\
\text { (month/day/ } \\
\text { year) }\end{array}$ & Time & $\begin{array}{l}\text { Phenan- } \\
\text { threne, water, } \\
\text { unfiltered, } \\
\text { recoverable } \\
\text { (micrograms } \\
\text { per liter) } \\
\text { (34461) }\end{array}$ & $\begin{array}{c}\text { Phenol, } \\
\text { water, } \\
\text { filtered, } \\
\text { recoverable } \\
\text { (micrograms } \\
\text { per liter) } \\
\text { (34466) }\end{array}$ & $\begin{array}{c}\text { Phorate, } \\
\text { water, filtered } \\
\text { (0.7-micron } \\
\text { glass fiber } \\
\text { filter), } \\
\text { recoverable } \\
\text { (micrograms } \\
\text { per liter) } \\
\text { (82664) }\end{array}$ & $\begin{array}{c}\text { Prometon, } \\
\text { water, } \\
\text { filtered, } \\
\text { recoverable } \\
\text { (micrograms } \\
\text { per liter) } \\
\text { (04037) }\end{array}$ & $\begin{array}{c}\text { Propyzamide, } \\
\text { water, filtered } \\
\text { (0.7-micron } \\
\text { glass fiber } \\
\text { filter), } \\
\text { recoverable } \\
\text { (micrograms } \\
\text { per liter) } \\
\text { (82676) }\end{array}$ & $\begin{array}{l}\text { Propach- } \\
\text { lor, water, } \\
\text { filtered, } \\
\text { recoverable } \\
\text { (micrograms } \\
\text { per liter) } \\
\text { (04024) }\end{array}$ & $\begin{array}{c}\text { Propanil, water, } \\
\text { filtered } \\
\text { (0.7-micron } \\
\text { glass fiber } \\
\text { filter), } \\
\text { recoverable } \\
\text { (micrograms } \\
\text { per liter) } \\
\text { (82679) }\end{array}$ \\
\hline $8 / 28 / 03$ & 9:00 & $<2$ & $<0.5$ & $<0.011$ & M & $<0.004$ & $<0.010$ & $<0.011$ \\
\hline $12 / 15 / 03$ & 11:00 & -- & $<.5$ & $<.011$ & 0.01 & $<.004$ & $<.025$ & $<.011$ \\
\hline $2 / 4 / 04$ & $9: 00$ & -- & $<.5$ & $<.011$ & $<.01$ & $<.004$ & $<.025$ & $<.011$ \\
\hline $3 / 1 / 04$ & $9: 00$ & -- & $<.5$ & $<.011$ & $<.01$ & $<.004$ & $<.025$ & $<.011$ \\
\hline $8 / 25 / 04$ & $9: 30$ & $<2$ & $<.5$ & $<.011$ & 0.01 & $<.004$ & $<.025$ & $<.011$ \\
\hline $11 / 1 / 04$ & 10:00 & -- & $<.5$ & $<.011$ & $<.01$ & $<.004$ & $<.025$ & $<.011$ \\
\hline $\begin{array}{c}\text { Sample } \\
\text { date } \\
\text { (month/day/ } \\
\text { year) }\end{array}$ & Time & $\begin{array}{c}\text { Propargite, } \\
\text { water, filtered } \\
\text { (0.7-micron } \\
\text { glass fiber } \\
\text { filter), } \\
\text { recoverable } \\
\text { (micrograms } \\
\text { per liter) } \\
\text { (82685) }\end{array}$ & $\begin{array}{c}\text { Pyrene, } \\
\text { water, } \\
\text { filtered, } \\
\text { recoverable } \\
\text { (micrograms } \\
\text { per liter) } \\
\text { (34470) }\end{array}$ & $\begin{array}{c}\text { Pyrene, water, } \\
\text { unfiltered, } \\
\text { recoverable } \\
\text { (micrograms } \\
\text { per liter) } \\
\text { (34469) }\end{array}$ & $\begin{array}{c}\text { Simazine, } \\
\text { water, } \\
\text { filtered, } \\
\text { recoverable } \\
\text { (micrograms } \\
\text { per liter) } \\
\text { (04035) }\end{array}$ & $\begin{array}{c}\text { Tebuthiuron, } \\
\text { water, filtered } \\
\text { (0.7-micron } \\
\text { glass fiber } \\
\text { filter), } \\
\text { recoverable } \\
\text { (micrograms } \\
\text { per liter) } \\
\text { (82670) }\end{array}$ & $\begin{array}{c}\text { Terbacil, } \\
\text { water, } \\
\text { filtered } \\
\text { (0.7-micron } \\
\text { glass } \\
\text { fiber filter), } \\
\text { recoverable } \\
\text { (micrograms } \\
\text { per liter) } \\
\text { (82665) }\end{array}$ & $\begin{array}{l}\text { Terbufos, water, } \\
\text { filtered } \\
\text { (0.7-micron } \\
\text { glass fiber } \\
\text { filter), } \\
\text { recoverable } \\
\text { (micrograms } \\
\text { per liter) } \\
\text { (82675) }\end{array}$ \\
\hline $5 / 24 / 04$ & 11:00 & $<.02$ & $<.5$ & -- & .064 & $<.02$ & $<.034$ & $<.02$ \\
\hline $6 / 14 / 04$ & $13: 30$ & $<.02$ & $<.5$ & -- & .053 & $<.02$ & $<.034$ & $<.02$ \\
\hline 7/19/04 & $9: 30$ & $<.02$ & $<.5$ & -- & .019 & $<.02$ & $<.034$ & $<.02$ \\
\hline $8 / 25 / 04$ & $9: 30$ & $<.02$ & $<.5$ & $<2$ & $<.005$ & $<.02$ & $<.034$ & $<.02$ \\
\hline $11 / 1 / 04$ & 10:00 & $<.02$ & $<.5$ & -- & $<.005$ & $<.02$ & $<.034$ & $<.02$ \\
\hline
\end{tabular}


Appendix 5. Water-quality constituents in samples from Cardwell Branch (USGS station 404413096431401), Nebraska, 2003-04.—Continued

[National Water Information System parameter codes associated with each constituent given in parentheses; remark codes used in the table: E, estimated; <, less than; --, not measured; M, constituent was detected but not quantified; V, constituent may be affected by presumed contamination sources]

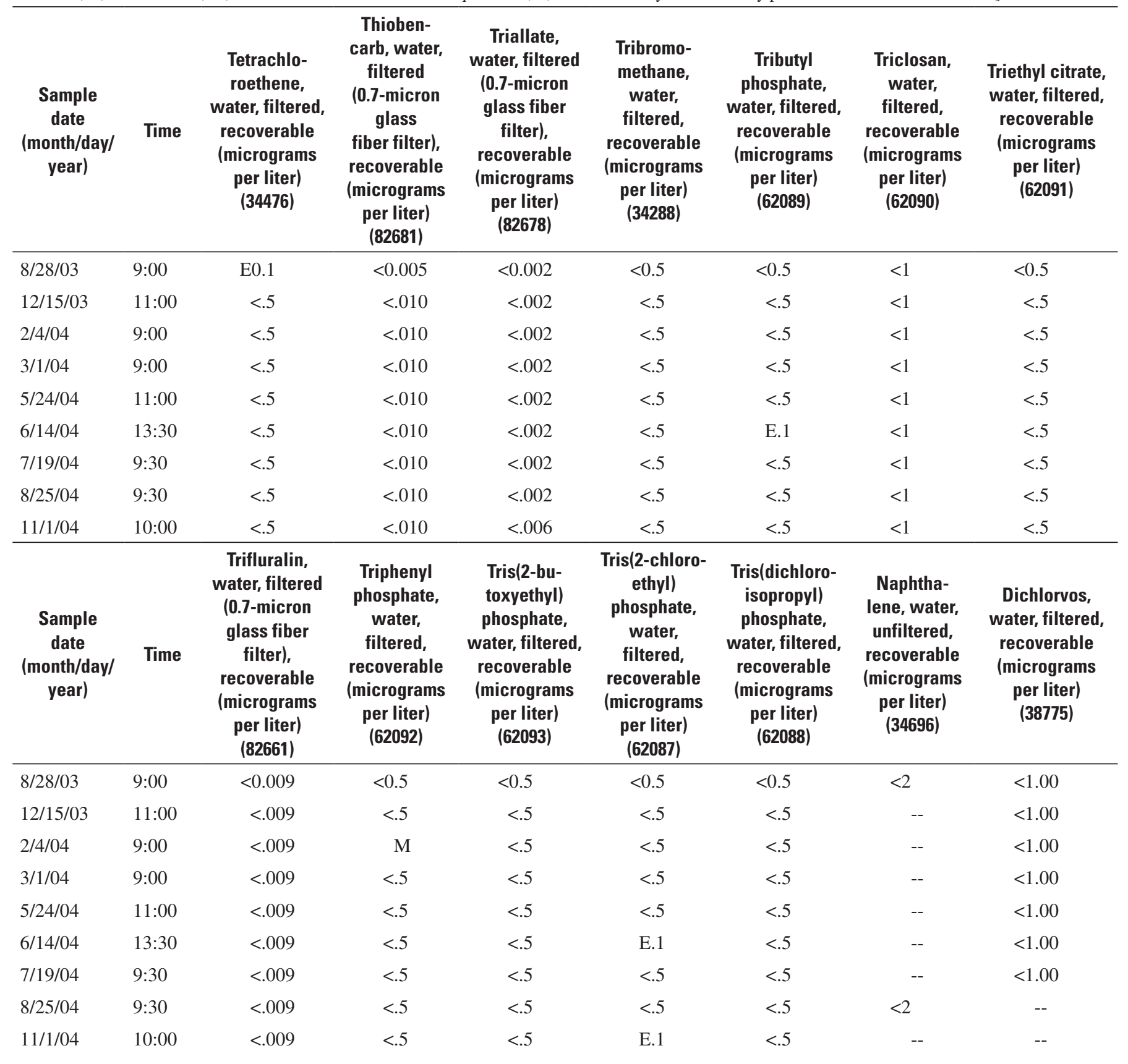


Appendix 5. Water-quality constituents in samples from Cardwell Branch (USGS station 404413096431401), Nebraska, 2003-04.-Continued

[National Water Information System parameter codes associated with each constituent given in parentheses; remark codes used in the table: E, estimated; <, less than; --, not measured; M, constituent was detected but not quantified; V, constituent may be affected by presumed contamination sources]

\begin{tabular}{|c|c|c|c|c|c|}
\hline $\begin{array}{c}\text { Sample } \\
\text { date } \\
\text { (month/day/ } \\
\text { year) }\end{array}$ & Time & $\begin{array}{c}\text { Escherichia coli, } \\
\text { modified m-TEC membrane } \\
\text { filtration method, water } \\
\text { (colonies per } 100 \text { millili- } \\
\text { ters) (90902) }\end{array}$ & $\begin{array}{l}\text { Chlorophyll a, periphyton, } \\
\text { chromatographic-fluoro- } \\
\text { metric method (milligrams } \\
\text { per square meter) (70957) }\end{array}$ & $\begin{array}{c}\text { Pheophytin } \\
\text { a, periphyton } \\
\text { (milligrams per } \\
\text { square) meter } \\
\text { (62359) }\end{array}$ & $\begin{array}{c}\text { Total suspended } \\
\text { solids } \\
\text { (milligrams per } \\
\text { liter) (00530) }\end{array}$ \\
\hline $8 / 28 / 03$ & 9:00 & -- & 2.8 & 4.1 & 54 \\
\hline $12 / 15 / 03$ & $11: 00$ & -- & -- & -- & $<10$ \\
\hline 2/4/04 & 9:00 & -- & -- & -- & 18 \\
\hline 3/1/04 & 9:00 & -- & -- & -- & 54 \\
\hline $5 / 24 / 04$ & $11: 00$ & -- & -- & -- & 610 \\
\hline $6 / 14 / 04$ & $13: 30$ & $\mathrm{E} 4,900$ & -- & -- & 500 \\
\hline $7 / 19 / 04$ & $9: 30$ & 1,400 & -- & -- & 140 \\
\hline $8 / 25 / 04$ & $9: 30$ & 200 & -- & -- & 24 \\
\hline $11 / 1 / 04$ & $10: 00$ & E120 & -- & -- & 66 \\
\hline
\end{tabular}




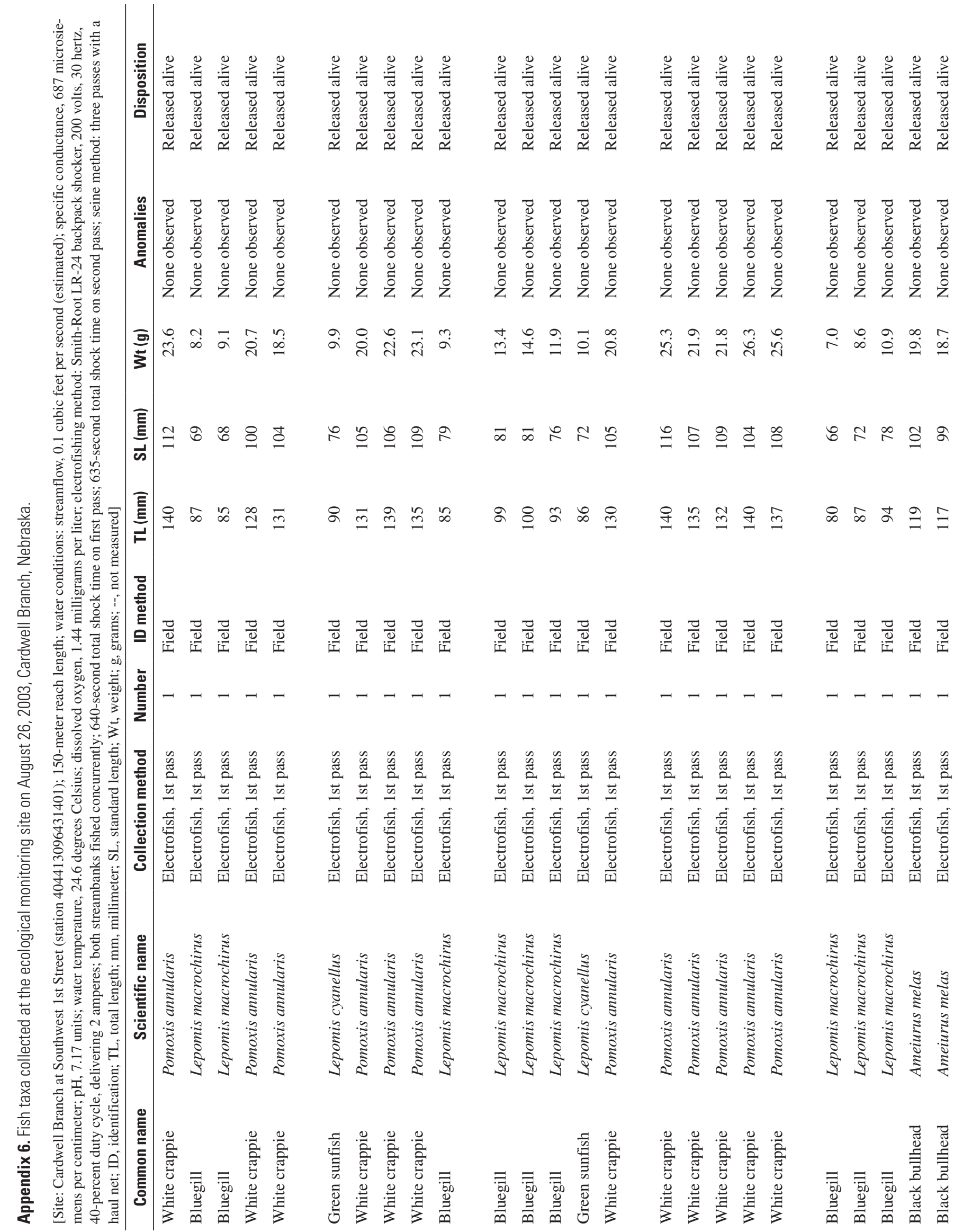




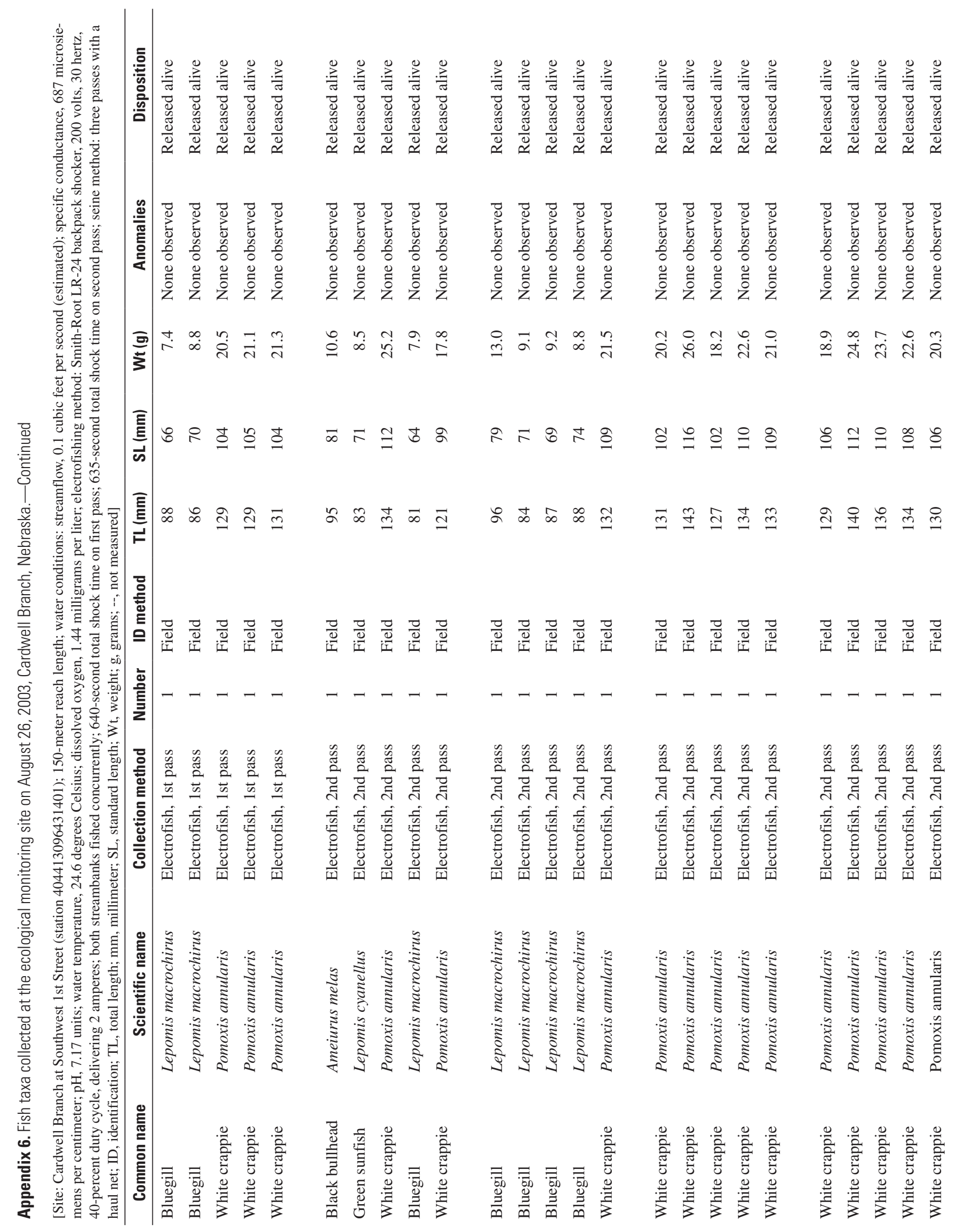




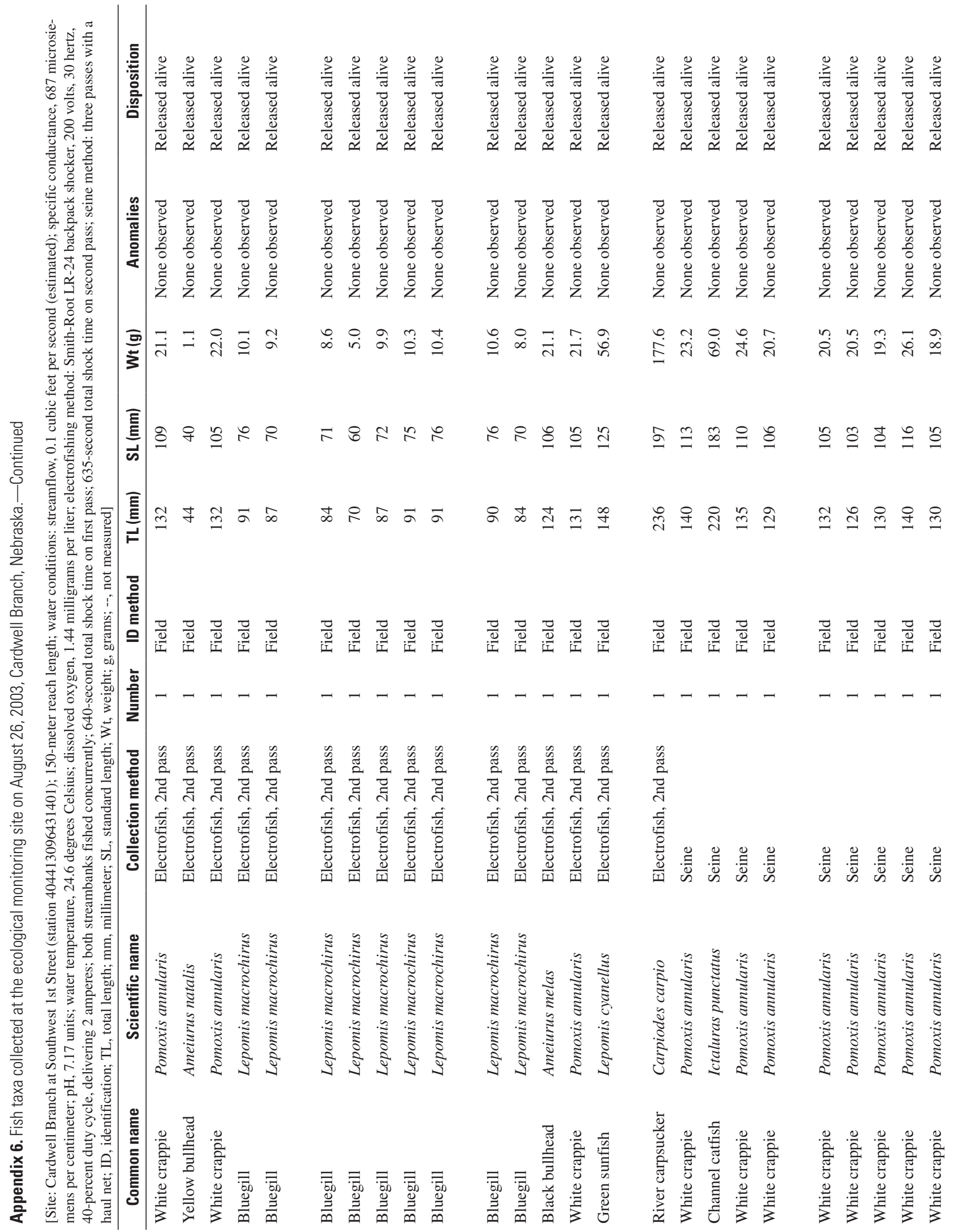




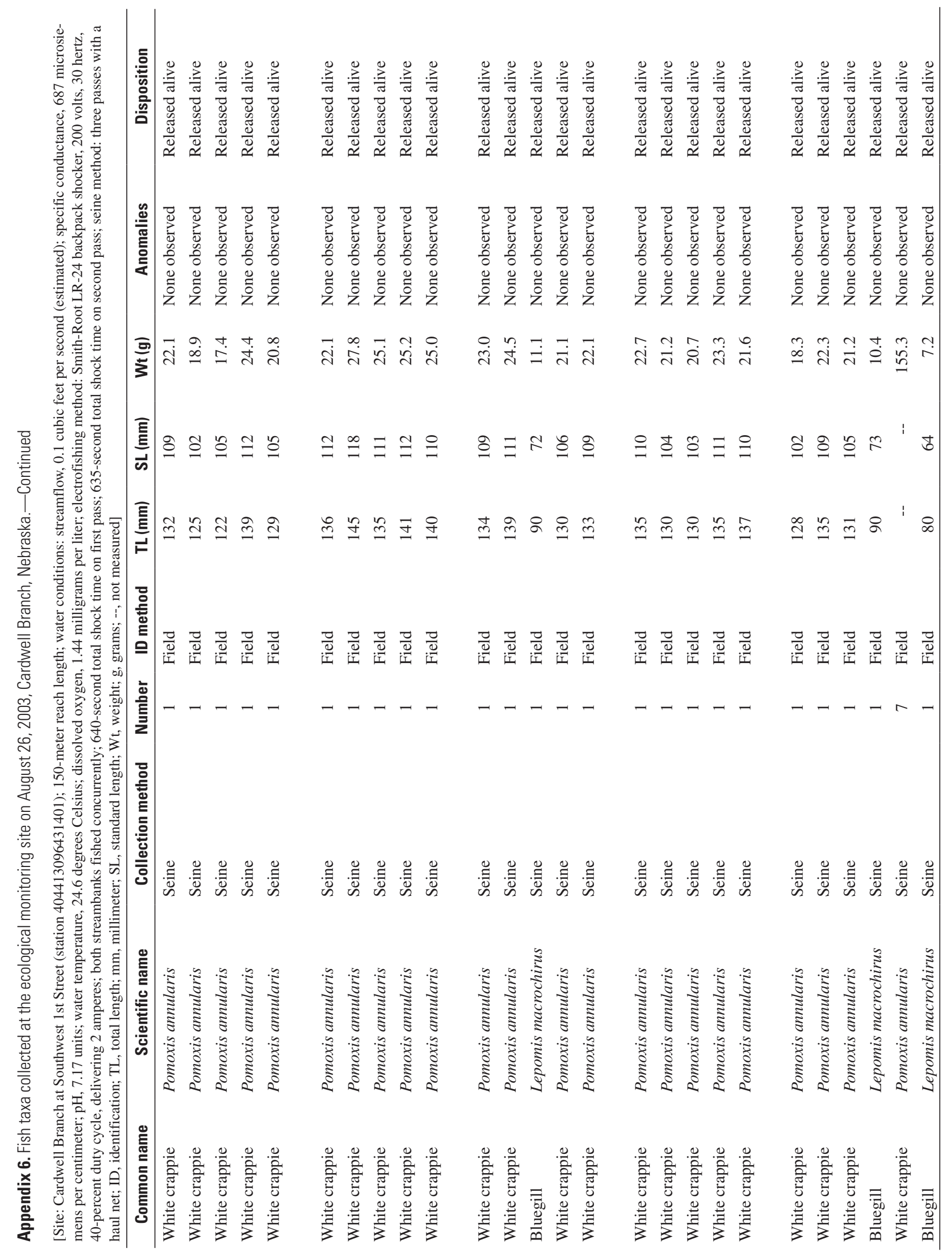




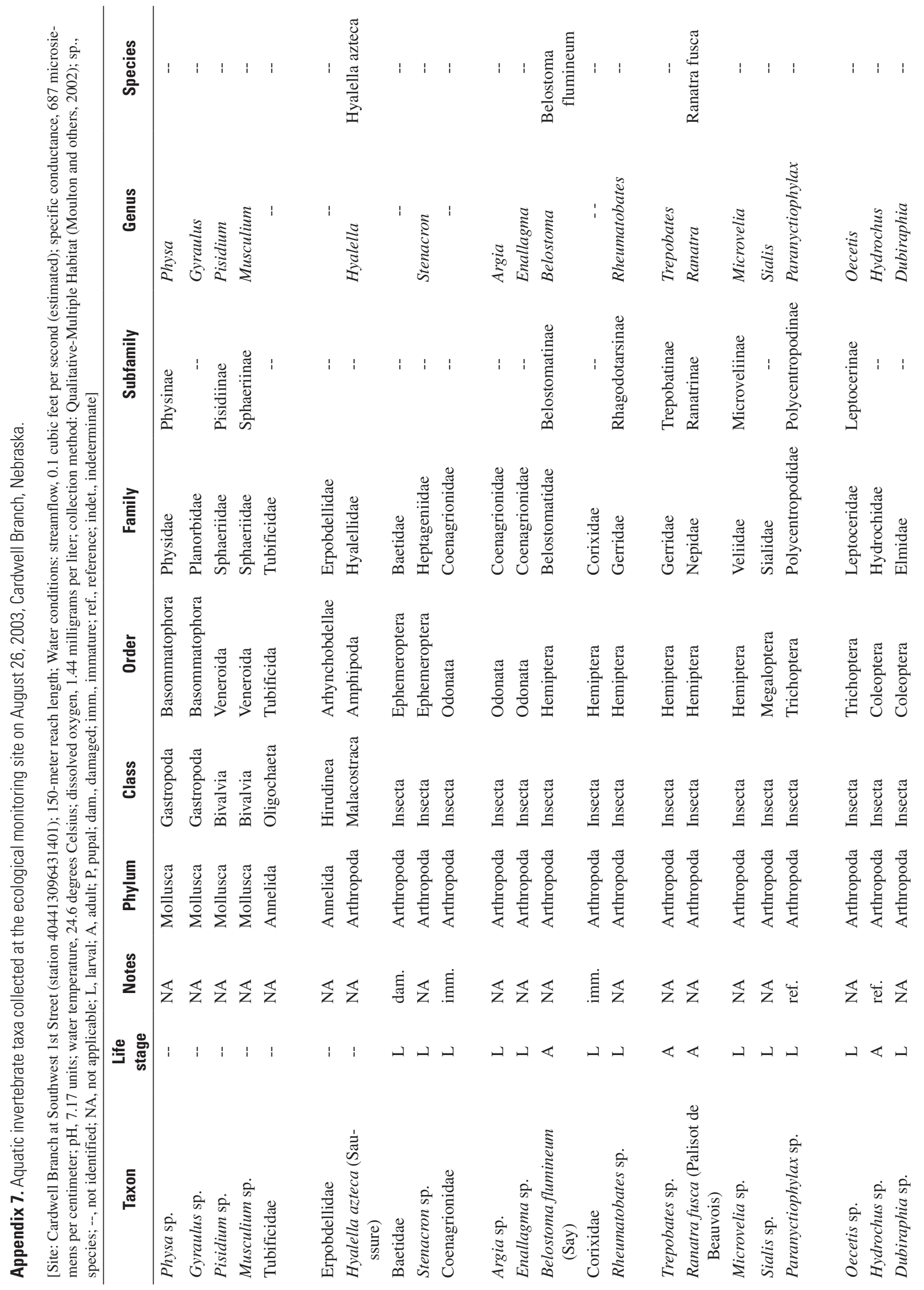




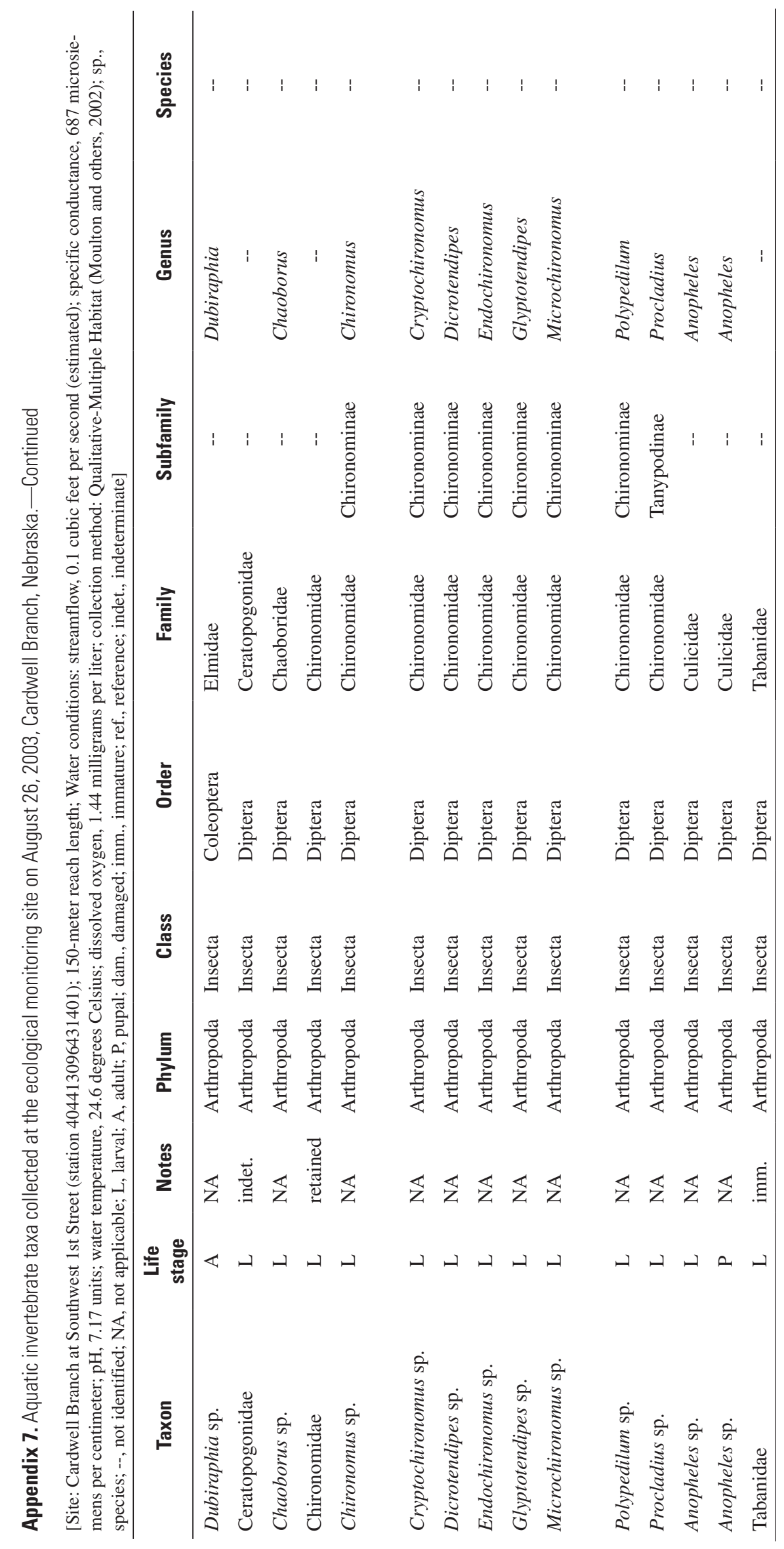


Appendix 8. Algal taxa collected at the ecological monitoring site on August 26, 2003, Cardwell Branch, Nebraska.

[Site: Cardwell Branch at Southwest 1st Street (station 404413096431401); 150-meter reach length; water conditions: streamflow, 0.1 cubic feet per second (estimated); specific conductance, 687 microsiemens per centimeter; pH, 7.17 units; water temperature, 24.6 degrees Celsius; dissolved oxygen, 1.44 milligrams per liter; collection method: Qualitative-Multiple Habitat (Moulton and others, 2002); Obs., observed, but not counted; --, not identified]

\begin{tabular}{|c|c|c|c|c|c|}
\hline Division & Common division name & Genus & Species & Variety & Count \\
\hline Bacillariophyta & Diatomaceous algae & Achnanthidium & minutissimum & -- & Obs. \\
\hline Bacillariophyta & Diatomaceous algae & Amphora & copulata & -- & Obs. \\
\hline Bacillariophyta & Diatomaceous algae & Amphora & montana & -- & Obs. \\
\hline Bacillariophyta & Diatomaceous algae & Aulacoseira & canadensis & -- & Obs. \\
\hline Bacillariophyta & Diatomaceous algae & Aulacoseira & granulata & -- & Obs. \\
\hline Bacillariophyta & Diatomaceous algae & Caloneis & bacillum & -- & Obs. \\
\hline Bacillariophyta & Diatomaceous algae & Caloneis & schumanniana & -- & Obs. \\
\hline Bacillariophyta & Diatomaceous algae & Caloneis & silicula & -- & Obs. \\
\hline Bacillariophyta & Diatomaceous algae & Cocconeis & placentula & -- & 13 \\
\hline Bacillariophyta & Diatomaceous algae & Craticula & ambigua & -- & 2 \\
\hline Bacillariophyta & Diatomaceous algae & Craticula & citrus & -- & Obs. \\
\hline Bacillariophyta & Diatomaceous algae & Cymbella & -- & -- & Obs. \\
\hline Bacillariophyta & Diatomaceous algae & Cymbella & triangulum & -- & 7 \\
\hline Bacillariophyta & Diatomaceous algae & Encyonema & silesiacum & -- & Obs. \\
\hline Bacillariophyta & Diatomaceous algae & Eolimna & minima & -- & 12 \\
\hline Bacillariophyta & Diatomaceous algae & Fallacia & tenera & -- & Obs. \\
\hline Bacillariophyta & Diatomaceous algae & Gomphonema & affine & -- & Obs. \\
\hline Bacillariophyta & Diatomaceous algae & Gomphonema & angustatum & -- & 18 \\
\hline Bacillariophyta & Diatomaceous algae & Gomphonema & gracile & -- & Obs. \\
\hline Bacillariophyta & Diatomaceous algae & Gomphonema & kobayasii & -- & Obs. \\
\hline Bacillariophyta & Diatomaceous algae & Gomphonema & parvulum & -- & 20 \\
\hline Bacillariophyta & Diatomaceous algae & Gyrosigma & acuminatum & -- & Obs. \\
\hline Bacillariophyta & Diatomaceous algae & Gyrosigma & scalproides & -- & 3 \\
\hline Bacillariophyta & Diatomaceous algae & Hantzschia & amphioxys & -- & Obs. \\
\hline Bacillariophyta & Diatomaceous algae & Hippodonta & hungarica & -- & Obs. \\
\hline Bacillariophyta & Diatomaceous algae & Luticola & mutica & -- & Obs. \\
\hline Bacillariophyta & Diatomaceous algae & Luticola & -- & -- & Obs. \\
\hline Bacillariophyta & Diatomaceous algae & Navicula & erifuga & -- & 25 \\
\hline Bacillariophyta & Diatomaceous algae & Navicula & libonensis & -- & Obs. \\
\hline Bacillariophyta & Diatomaceous algae & Navicula & menisculus & -- & Obs. \\
\hline Bacillariophyta & Diatomaceous algae & Navicula & oligotraphenta & -- & Obs. \\
\hline Bacillariophyta & Diatomaceous algae & Navicula & recens & -- & Obs. \\
\hline Bacillariophyta & Diatomaceous algae & Navicula & salinicola & -- & 4 \\
\hline Bacillariophyta & Diatomaceous algae & Navicula & schroeterii & -- & Obs. \\
\hline Bacillariophyta & Diatomaceous algae & Navicula & subminuscula & -- & Obs. \\
\hline
\end{tabular}


Appendix 8. Algal taxa collected at the ecological monitoring site on August 26, 2003, Cardwell Branch, Nebraska.—Continued

[Site: Cardwell Branch at Southwest 1st Street (station 404413096431401); 150-meter reach length; water conditions: streamflow, 0.1 cubic feet per second (estimated); specific conductance, 687 microsiemens per centimeter; $\mathrm{pH}, 7.17$ units; water temperature, 24.6 degrees Celsius; dissolved oxygen, 1.44 milligrams per liter; collection method: Qualitative-Multiple Habitat (Moulton and others, 2002); Obs., observed, but not counted; --, not identified]

\begin{tabular}{|c|c|c|c|c|c|}
\hline Division & Common division name & Genus & Species & Variety & Count \\
\hline Bacillariophyta & Diatomaceous algae & Navicula & symmetrica & -- & 3 \\
\hline Bacillariophyta & Diatomaceous algae & Navicula & trivialis & -- & 8 \\
\hline Bacillariophyta & Diatomaceous algae & Navicula & veneta & -- & Obs. \\
\hline Bacillariophyta & Diatomaceous algae & Nitzschia & amphibia & -- & 45 \\
\hline Bacillariophyta & Diatomaceous algae & Nitzschia & angustatula & -- & 4 \\
\hline Bacillariophyta & Diatomaceous algae & Nitzschia & frustulum & -- & 4 \\
\hline Bacillariophyta & Diatomaceous algae & Nitzschia & frustulum & v. subsalina & 8 \\
\hline Bacillariophyta & Diatomaceous algae & Nitzschia & intermedia & -- & Obs. \\
\hline Bacillariophyta & Diatomaceous algae & Nitzschia & linearis & -- & 4 \\
\hline Bacillariophyta & Diatomaceous algae & Nitzschia & palea & -- & Obs. \\
\hline Bacillariophyta & Diatomaceous algae & Nitzschia & rosenstockii & -- & Obs. \\
\hline Bacillariophyta & Diatomaceous algae & Nitzschia & sigma & -- & 2 \\
\hline Bacillariophyta & Diatomaceous algae & Nitzschia & siliqua & -- & Obs. \\
\hline Bacillariophyta & Diatomaceous algae & Nitzschia & -- & -- & Obs. \\
\hline Bacillariophyta & Diatomaceous algae & Nitzschia & supralitorea & -- & 3 \\
\hline Bacillariophyta & Diatomaceous algae & Nitzschia & umbonata & -- & Obs. \\
\hline Bacillariophyta & Diatomaceous algae & Nitzschia & valdestriata & -- & Obs. \\
\hline Bacillariophyta & Diatomaceous algae & Nitzschia & vitrea & -- & Obs. \\
\hline Bacillariophyta & Diatomaceous algae & Pinnularia & microstauron & -- & Obs. \\
\hline Bacillariophyta & Diatomaceous algae & Planothidium & frequentissimum & -- & Obs. \\
\hline Bacillariophyta & Diatomaceous algae & Rhoicosphenia & abbreviata & -- & 1 \\
\hline Bacillariophyta & Diatomaceous algae & Rhopalodia & brebissonii & -- & Obs. \\
\hline Bacillariophyta & Diatomaceous algae & Stauroneis & anceps & -- & Obs. \\
\hline Bacillariophyta & Diatomaceous algae & Stauroneis & anceps & f. gracilis & Obs. \\
\hline Bacillariophyta & Diatomaceous algae & Stauroneis & -- & -- & Obs. \\
\hline Bacillariophyta & Diatomaceous algae & Stephanocyclus & meneghiniana & -- & 6 \\
\hline Bacillariophyta & Diatomaceous algae & Surirella & angusta & -- & Obs. \\
\hline Bacillariophyta & Diatomaceous algae & Tryblionella & apiculata & -- & Obs. \\
\hline Bacillariophyta & Diatomaceous algae & Tryblionella & calida & -- & 8 \\
\hline Bacillariophyta & Diatomaceous algae & Tryblionella & hungarica & -- & Obs. \\
\hline Chlorophyta & Green Algae & Ankistrodesmus & -- & -- & Obs. \\
\hline Euglenophyta & Euglenoid Algae & Euglena & -- & -- & Obs. \\
\hline Cyanophyta & Cyanobacteria (blue-green algae) & Geitlerinema & -- & -- & Obs. \\
\hline Cyanophyta & Cyanobacteria (blue-green algae) & Hyella & -- & -- & Obs. \\
\hline Cyanophyta & Cyanobacteria (blue-green algae) & Planktothrix & -- & -- & Obs. \\
\hline Cyanophyta & Cyanobacteria (blue-green algae) & Pseudanabaena & -- & -- & Obs. \\
\hline
\end{tabular}


Appendix 9. Potential aquatic habitat observed in the Cardwell Branch study area, 2003-04.

[XSID, cross-sectional identifier; C, Cardwell Branch; T1, unnamed tributary; Y, present; N, not present; NA, not enough information to assess]

\begin{tabular}{|c|c|c|c|c|c|c|c|}
\hline XSID & $\begin{array}{l}\text { Geomorphic } \\
\text { reach (fig. 3) }\end{array}$ & Stream & $\begin{array}{l}\text { Woody } \\
\text { debris }\end{array}$ & $\begin{array}{c}\text { Overhanging } \\
\text { vegetation }\end{array}$ & $\begin{array}{c}\text { Undercut } \\
\text { banks }\end{array}$ & $\begin{array}{c}\text { Artificial } \\
\text { habitat }\end{array}$ & No habitat \\
\hline C-77-SB-APP & 5 & $\mathrm{C}$ & $\mathrm{Y}$ & $\mathrm{Y}$ & $\mathrm{N}$ & $\mathrm{N}$ & $\mathrm{N}$ \\
\hline C-23-01 & 5 & $\mathrm{C}$ & $\mathrm{N}$ & $\mathrm{N}$ & $\mathrm{N}$ & $\mathrm{Y}$ & $\mathrm{N}$ \\
\hline C-RR-EX & 5 & $\mathrm{C}$ & $\mathrm{Y}$ & $\mathrm{Y}$ & $\mathrm{Y}$ & $\mathrm{N}$ & $\mathrm{N}$ \\
\hline C-RR-APP & 5 & $\mathrm{C}$ & $\mathrm{Y}$ & Y & $\mathrm{N}$ & $\mathrm{N}$ & $\mathrm{N}$ \\
\hline C-1st-EX & 5 & $\mathrm{C}$ & $\mathrm{Y}$ & $\mathrm{Y}$ & $\mathrm{N}$ & $\mathrm{N}$ & $\mathrm{N}$ \\
\hline C-1st-APP & 5 & $\mathrm{C}$ & $\mathrm{Y}$ & Y & $\mathrm{N}$ & $\mathrm{N}$ & $\mathrm{N}$ \\
\hline C-22-57 & 5 & $\mathrm{C}$ & $\mathrm{Y}$ & $\mathrm{Y}$ & $\mathrm{N}$ & $\mathrm{N}$ & $\mathrm{N}$ \\
\hline$C-22-56$ & 5 & $\mathrm{C}$ & Y & $\mathrm{Y}$ & $\mathrm{N}$ & $\mathrm{N}$ & $\mathrm{N}$ \\
\hline $\mathrm{C}-22-55$ & 5 & $\mathrm{C}$ & $\mathrm{Y}$ & $\mathrm{Y}$ & $\mathrm{N}$ & $\mathrm{N}$ & $\mathrm{N}$ \\
\hline C-22-54 & 5 & $\mathrm{C}$ & $\mathrm{Y}$ & $\mathrm{N}$ & $\mathrm{N}$ & $\mathrm{N}$ & $\mathrm{N}$ \\
\hline$C-22-53$ & 4 & $\mathrm{C}$ & NA & NA & NA & NA & NA \\
\hline $\mathrm{C}-22-52$ & 4 & $\mathrm{C}$ & $\mathrm{Y}$ & $\mathrm{N}$ & $\mathrm{N}$ & $\mathrm{N}$ & $\mathrm{N}$ \\
\hline C-22-51 & 4 & $\mathrm{C}$ & NA & NA & NA & NA & NA \\
\hline C-22-06 & 4 & $\mathrm{C}$ & NA & NA & NA & NA & NA \\
\hline C-22-50 & 4 & $\mathrm{C}$ & $\mathrm{N}$ & $\mathrm{N}$ & $\mathrm{N}$ & $\mathrm{N}$ & $\mathrm{Y}$ \\
\hline C-22-05 & 4 & $\mathrm{C}$ & $\mathrm{N}$ & $\mathrm{N}$ & $\mathrm{Y}$ & $\mathrm{N}$ & $\mathrm{N}$ \\
\hline C-22-04 & 4 & $\mathrm{C}$ & NA & NA & NA & NA & NA \\
\hline $\mathrm{C}-22-03$ & 4 & $\mathrm{C}$ & $\mathrm{N}$ & $\mathrm{N}$ & $\mathrm{N}$ & $\mathrm{N}$ & $\mathrm{Y}$ \\
\hline C-22-02 & 4 & $\mathrm{C}$ & $\mathrm{N}$ & $\mathrm{N}$ & $\mathrm{Y}$ & $\mathrm{N}$ & $\mathrm{N}$ \\
\hline $\mathrm{C}-22-01$ & 4 & $\mathrm{C}$ & $\mathrm{Y}$ & $\mathrm{N}$ & $\mathrm{N}$ & $\mathrm{N}$ & $\mathrm{N}$ \\
\hline C-12TH-EX & 4 & $\mathrm{C}$ & $\mathrm{N}$ & $\mathrm{Y}$ & $\mathrm{N}$ & $\mathrm{N}$ & $\mathrm{N}$ \\
\hline C-12TH-APP & 4 & $\mathrm{C}$ & $\mathrm{Y}$ & $\mathrm{Y}$ & $\mathrm{N}$ & $\mathrm{N}$ & $\mathrm{N}$ \\
\hline C-21-01 & 4 & $\mathrm{C}$ & Y & $\mathrm{Y}$ & $\mathrm{N}$ & $\mathrm{N}$ & $\mathrm{N}$ \\
\hline C-21-02 & 4 & $\mathrm{C}$ & $\mathrm{Y}$ & $\mathrm{N}$ & $\mathrm{N}$ & $\mathrm{N}$ & $\mathrm{N}$ \\
\hline $\mathrm{C}-21-03$ & 4 & $\mathrm{C}$ & $\mathrm{Y}$ & $\mathrm{Y}$ & $\mathrm{N}$ & $\mathrm{N}$ & $\mathrm{N}$ \\
\hline C-21-04 & 4 & $\mathrm{C}$ & $\mathrm{Y}$ & $\mathrm{Y}$ & $\mathrm{N}$ & $\mathrm{N}$ & $\mathrm{N}$ \\
\hline $\mathrm{C}-21-05$ & 4 & $\mathrm{C}$ & NA & NA & NA & NA & NA \\
\hline $\mathrm{C}-21-06$ & 4 & $\mathrm{C}$ & NA & NA & NA & NA & NA \\
\hline C-21-07 & 4 & $\mathrm{C}$ & $\mathrm{Y}$ & $\mathrm{Y}$ & $\mathrm{N}$ & $\mathrm{N}$ & $\mathrm{N}$ \\
\hline $\mathrm{C}-21-55$ & 4 & $\mathrm{C}$ & $\mathrm{Y}$ & $\mathrm{N}$ & $\mathrm{N}$ & $\mathrm{N}$ & $\mathrm{N}$ \\
\hline C-21-54 & 4 & $\mathrm{C}$ & $\mathrm{Y}$ & Y & $\mathrm{N}$ & $\mathrm{N}$ & $\mathrm{N}$ \\
\hline C-21-53-DS & 4 & $\mathrm{C}$ & NA & NA & NA & NA & NA \\
\hline C-21-53-US & 4 & $\mathrm{C}$ & $\mathrm{Y}$ & Y & $\mathrm{N}$ & $\mathrm{N}$ & $\mathrm{N}$ \\
\hline$C-21-52$ & 4 & $\mathrm{C}$ & NA & NA & NA & NA & NA \\
\hline $\mathrm{C}-21-51$ & 4 & $\mathrm{C}$ & $\mathrm{N}$ & Y & $\mathrm{N}$ & $\mathrm{N}$ & $\mathrm{N}$ \\
\hline$C-21-50$ & 1 & $\mathrm{C}$ & Y & Y & $\mathrm{N}$ & $\mathrm{N}$ & $\mathrm{N}$ \\
\hline C-27TH-EX & 1 & $\mathrm{C}$ & $\mathrm{Y}$ & $\mathrm{Y}$ & $\mathrm{N}$ & $\mathrm{N}$ & $\mathrm{N}$ \\
\hline C-27TH-APP & 1 & $\mathrm{C}$ & Y & $\mathrm{Y}$ & $\mathrm{N}$ & $\mathrm{N}$ & $\mathrm{N}$ \\
\hline C-20-18 & 1 & $\mathrm{C}$ & $\mathrm{Y}$ & $\mathrm{Y}$ & $\mathrm{Y}$ & $\mathrm{N}$ & $\mathrm{N}$ \\
\hline
\end{tabular}


Appendix 9. Potential aquatic habitat observed in the Cardwell Branch study area, 2003-04.-Continued

[XSID, cross-sectional identifier; C, Cardwell Branch; T1, unnamed tributary; Y, present; N, not present; NA, not enough information to assess]

\begin{tabular}{|c|c|c|c|c|c|c|c|}
\hline XSID & $\begin{array}{l}\text { Geomorphic } \\
\text { reach (fig. 3) }\end{array}$ & Stream & $\begin{array}{l}\text { Woody } \\
\text { debris }\end{array}$ & $\begin{array}{l}\text { Overhanging } \\
\text { vegetation }\end{array}$ & $\begin{array}{l}\text { Undercut } \\
\text { banks }\end{array}$ & $\begin{array}{c}\text { Artificial } \\
\text { habitat }\end{array}$ & No habitat \\
\hline C-20-17 & 1 & $\mathrm{C}$ & $\mathrm{Y}$ & $\mathrm{Y}$ & $\mathrm{Y}$ & $\mathrm{N}$ & $\mathrm{N}$ \\
\hline C-20-16 & 1 & $\mathrm{C}$ & $\mathrm{Y}$ & Y & $\mathrm{N}$ & $\mathrm{N}$ & $\mathrm{N}$ \\
\hline C-20-15 & 1 & $\mathrm{C}$ & Y & Y & $\mathrm{N}$ & $\mathrm{N}$ & $\mathrm{N}$ \\
\hline C-20-14 & 1 & $\mathrm{C}$ & Y & $\mathrm{N}$ & $\mathrm{N}$ & $\mathrm{N}$ & $\mathrm{N}$ \\
\hline C-20-13 & 1 & $\mathrm{C}$ & Y & Y & $\mathrm{N}$ & $\mathrm{N}$ & $\mathrm{N}$ \\
\hline C-20-12 & 1 & $\mathrm{C}$ & NA & NA & NA & NA & NA \\
\hline C-20-11 & 1 & $\mathrm{C}$ & Y & Y & $\mathrm{N}$ & $\mathrm{N}$ & $\mathrm{N}$ \\
\hline C-20-10 & 1 & $\mathrm{C}$ & NA & NA & NA & NA & NA \\
\hline C-20-09 & 1 & $\mathrm{C}$ & $\mathrm{Y}$ & Y & $\mathrm{N}$ & $\mathrm{N}$ & $\mathrm{N}$ \\
\hline C-20-08 & 1 & $\mathrm{C}$ & $\mathrm{Y}$ & Y & $\mathrm{N}$ & $\mathrm{N}$ & $\mathrm{N}$ \\
\hline C-20-07 & 1 & $\mathrm{C}$ & Y & Y & $\mathrm{N}$ & $\mathrm{N}$ & $\mathrm{N}$ \\
\hline C-20-06 & 1 & $\mathrm{C}$ & $\mathrm{Y}$ & $\mathrm{N}$ & $\mathrm{N}$ & $\mathrm{N}$ & $\mathrm{N}$ \\
\hline C-20-05 & 1 & $\mathrm{C}$ & NA & NA & NA & NA & NA \\
\hline C-20-04 & 1 & $\mathrm{C}$ & $\mathrm{N}$ & $\mathrm{Y}$ & $\mathrm{N}$ & $\mathrm{N}$ & $\mathrm{N}$ \\
\hline C-20-03 & 1 & $\mathrm{C}$ & $\mathrm{Y}$ & Y & $\mathrm{N}$ & $\mathrm{N}$ & $\mathrm{N}$ \\
\hline C-20-02 & 1 & $\mathrm{C}$ & NA & NA & NA & NA & NA \\
\hline C-20-01 & 1 & $\mathrm{C}$ & NA & NA & NA & NA & NA \\
\hline C-40TH-EX & 1 & $\mathrm{C}$ & $\mathrm{Y}$ & Y & $\mathrm{N}$ & $\mathrm{N}$ & $\mathrm{N}$ \\
\hline C-40TH-APP & 1 & $\mathrm{C}$ & $\mathrm{Y}$ & $\mathrm{N}$ & $\mathrm{N}$ & $\mathrm{N}$ & $\mathrm{N}$ \\
\hline C-19-09 & 1 & $\mathrm{C}$ & $\mathrm{N}$ & $\mathrm{N}$ & $\mathrm{N}$ & $\mathrm{N}$ & Y \\
\hline C-19-07 & 1 & $\mathrm{C}$ & $\mathrm{N}$ & $\mathrm{N}$ & $\mathrm{N}$ & $\mathrm{N}$ & Y \\
\hline C-19-06 & 1 & $\mathrm{C}$ & $\mathrm{N}$ & $\mathrm{N}$ & $\mathrm{N}$ & $\mathrm{N}$ & $\mathrm{Y}$ \\
\hline C-19-05 & 1 & $\mathrm{C}$ & $\mathrm{N}$ & $\mathrm{N}$ & $\mathrm{N}$ & $\mathrm{N}$ & $\mathrm{Y}$ \\
\hline C-19-04 & 1 & $\mathrm{C}$ & NA & NA & NA & NA & NA \\
\hline $\mathrm{T} 1-21-50$ & 3 & $\mathrm{~T} 1$ & $\mathrm{Y}$ & Y & $\mathrm{N}$ & $\mathrm{N}$ & $\mathrm{N}$ \\
\hline $\mathrm{T} 1-21-51$ & 3 & $\mathrm{~T} 1$ & $\mathrm{Y}$ & Y & $\mathrm{N}$ & $\mathrm{N}$ & $\mathrm{N}$ \\
\hline T1-CARDDR-APP & 3 & $\mathrm{~T} 1$ & $\mathrm{Y}$ & $\mathrm{N}$ & $\mathrm{N}$ & $\mathrm{N}$ & $\mathrm{N}$ \\
\hline $\mathrm{T} 1-21-52$ & 3 & $\mathrm{~T} 1$ & $\mathrm{~N}$ & $\mathrm{~N}$ & $\mathrm{~N}$ & $\mathrm{~N}$ & $\mathrm{Y}$ \\
\hline $\mathrm{T} 1-21-53$ & 3 & $\mathrm{~T} 1$ & $\mathrm{Y}$ & $\mathrm{N}$ & $\mathrm{N}$ & $\mathrm{N}$ & $\mathrm{N}$ \\
\hline T1-21-06 & 3 & $\mathrm{~T} 1$ & $\mathrm{Y}$ & $\mathrm{Y}$ & $\mathrm{N}$ & $\mathrm{N}$ & $\mathrm{N}$ \\
\hline $\mathrm{T} 1-21-54$ & 3 & $\mathrm{~T} 1$ & $\mathrm{Y}$ & $\mathrm{Y}$ & $\mathrm{N}$ & $\mathrm{N}$ & $\mathrm{N}$ \\
\hline $\mathrm{T} 1-21-05$ & 3 & $\mathrm{~T} 1$ & NA & NA & NA & NA & NA \\
\hline T1-21-04 & 3 & $\mathrm{~T} 1$ & NA & NA & NA & NA & NA \\
\hline T1-21-03 & 3 & $\mathrm{~T} 1$ & $\mathrm{Y}$ & $\mathrm{Y}$ & $\mathrm{Y}$ & $\mathrm{N}$ & $\mathrm{N}$ \\
\hline T1-21-02 & 3 & $\mathrm{~T} 1$ & $\mathrm{Y}$ & $\mathrm{Y}$ & $\mathrm{N}$ & $\mathrm{N}$ & $\mathrm{N}$ \\
\hline $\mathrm{T} 1-21-01$ & 3 & $\mathrm{~T} 1$ & NA & NA & NA & NA & NA \\
\hline T1-27TH-EX & 3 & $\mathrm{~T} 1$ & $\mathrm{~N}$ & $\mathrm{Y}$ & $\mathrm{N}$ & $\mathrm{N}$ & $\mathrm{N}$ \\
\hline T1-27TH-APP & 3 & $\mathrm{~T} 1$ & $\mathrm{~N}$ & $\mathrm{Y}$ & $\mathrm{N}$ & $\mathrm{N}$ & $\mathrm{N}$ \\
\hline $\mathrm{T} 1-20-01$ & 3 & $\mathrm{~T} 1$ & $\mathrm{Y}$ & $\mathrm{N}$ & $\mathrm{N}$ & $\mathrm{N}$ & $\mathrm{N}$ \\
\hline T1-20-02 & 3 & $\mathrm{~T} 1$ & $\mathrm{Y}$ & $\mathrm{Y}$ & $\mathrm{N}$ & $\mathrm{N}$ & $\mathrm{N}$ \\
\hline $\mathrm{T} 1-20-03$ & 3 & $\mathrm{~T} 1$ & $\mathrm{Y}$ & Y & $\mathrm{N}$ & $\mathrm{N}$ & $\mathrm{N}$ \\
\hline
\end{tabular}


Appendix 9. Potential aquatic habitat observed in the Cardwell Branch study area, 2003-04.-Continued

[XSID, cross-sectional identifier; C, Cardwell Branch; T1, unnamed tributary; Y, present; N, not present; NA, not enough information to assess.]

\begin{tabular}{|c|c|c|c|c|c|c|c|}
\hline XSID & $\begin{array}{l}\text { Geomorphic } \\
\text { reach (fig. 3) }\end{array}$ & Stream & $\begin{array}{l}\text { Woody } \\
\text { debris }\end{array}$ & $\begin{array}{l}\text { Overhanging } \\
\text { vegetation }\end{array}$ & $\begin{array}{l}\text { Undercut } \\
\text { banks }\end{array}$ & $\begin{array}{c}\text { Artificial } \\
\text { habitat }\end{array}$ & No habita \\
\hline T1-20-04 & 3 & $\mathrm{~T} 1$ & $\mathrm{~N}$ & Y & $\mathrm{N}$ & $\mathrm{N}$ & $\mathrm{N}$ \\
\hline T1-20-05 & 3 & $\mathrm{~T} 1$ & $\mathrm{~N}$ & Y & $\mathrm{N}$ & $\mathrm{N}$ & $\mathrm{N}$ \\
\hline T1-20-06 & 3 & $\mathrm{~T} 1$ & NA & NA & NA & NA & NA \\
\hline T1-29-01 & 3 & $\mathrm{~T} 1$ & Y & $\mathrm{N}$ & $\mathrm{N}$ & $\mathrm{N}$ & $\mathrm{N}$ \\
\hline T1-29-02 & 3 & $\mathrm{~T} 1$ & $\mathrm{~N}$ & $\mathrm{Y}$ & Y & $\mathrm{N}$ & $\mathrm{N}$ \\
\hline T1-29-03 & 2 & $\mathrm{~T} 1$ & $\mathrm{~N}$ & $\mathrm{Y}$ & $\mathrm{N}$ & $\mathrm{N}$ & $\mathrm{N}$ \\
\hline T1-CUL29-EX & 2 & $\mathrm{~T} 1$ & NA & NA & NA & NA & NA \\
\hline T1-CUL29-APP & 2 & $\mathrm{~T} 1$ & NA & NA & NA & NA & NA \\
\hline T1-29-04 & 2 & $\mathrm{~T} 1$ & NA & NA & NA & NA & NA \\
\hline T1-29-05 & 2 & $\mathrm{~T} 1$ & NA & NA & NA & NA & NA \\
\hline T1-29-06 & 2 & $\mathrm{~T} 1$ & Y & $\mathrm{Y}$ & $\mathrm{N}$ & $\mathrm{N}$ & $\mathrm{N}$ \\
\hline T1-29-07 & 2 & $\mathrm{~T} 1$ & NA & NA & NA & NA & NA \\
\hline T1-29-08 & 2 & $\mathrm{~T} 1$ & NA & NA & NA & NA & NA \\
\hline T1-ROK-EX & 2 & $\mathrm{~T} 1$ & NA & NA & NA & NA & NA \\
\hline T1-ROK-APP & 2 & $\mathrm{~T} 1$ & $\mathrm{~N}$ & $\mathrm{Y}$ & $\mathrm{N}$ & $\mathrm{N}$ & $\mathrm{N}$ \\
\hline T1-32-01 & 2 & $\mathrm{~T} 1$ & NA & NA & NA & NA & NA \\
\hline T1-32-02 & 2 & $\mathrm{~T} 1$ & NA & NA & NA & NA & NA \\
\hline T1-CUL32-EX & 2 & $\mathrm{~T} 1$ & NA & NA & NA & NA & NA \\
\hline T1-CUL32-APP & 2 & $\mathrm{~T} 1$ & NA & NA & NA & NA & NA \\
\hline T1-32-03 & 2 & $\mathrm{~T} 1$ & $\mathrm{~N}$ & $\mathrm{~N}$ & Y & $\mathrm{N}$ & $\mathrm{N}$ \\
\hline T1-32-04 & 2 & $\mathrm{~T} 1$ & NA & NA & NA & NA & NA \\
\hline T1-32-05 & 2 & $\mathrm{~T} 1$ & Y & $\mathrm{Y}$ & $\mathrm{N}$ & $\mathrm{N}$ & $\mathrm{N}$ \\
\hline Т1-32-06 & 2 & $\mathrm{~T} 1$ & $\mathrm{~N}$ & Y & $\mathrm{N}$ & $\mathrm{N}$ & $\mathrm{N}$ \\
\hline
\end{tabular}

Publishing support provided by:

Rolla Publishing Service Center

For more information concerning this publication, contact:

Director, USGS Nebraska Water Science Center

5231 S. 19 Street

Lincoln, NE 68512

(402) $328-4100$

Or visit the Nebraska Water Science Center Web site at:

http://ne.water.usgs.gov 


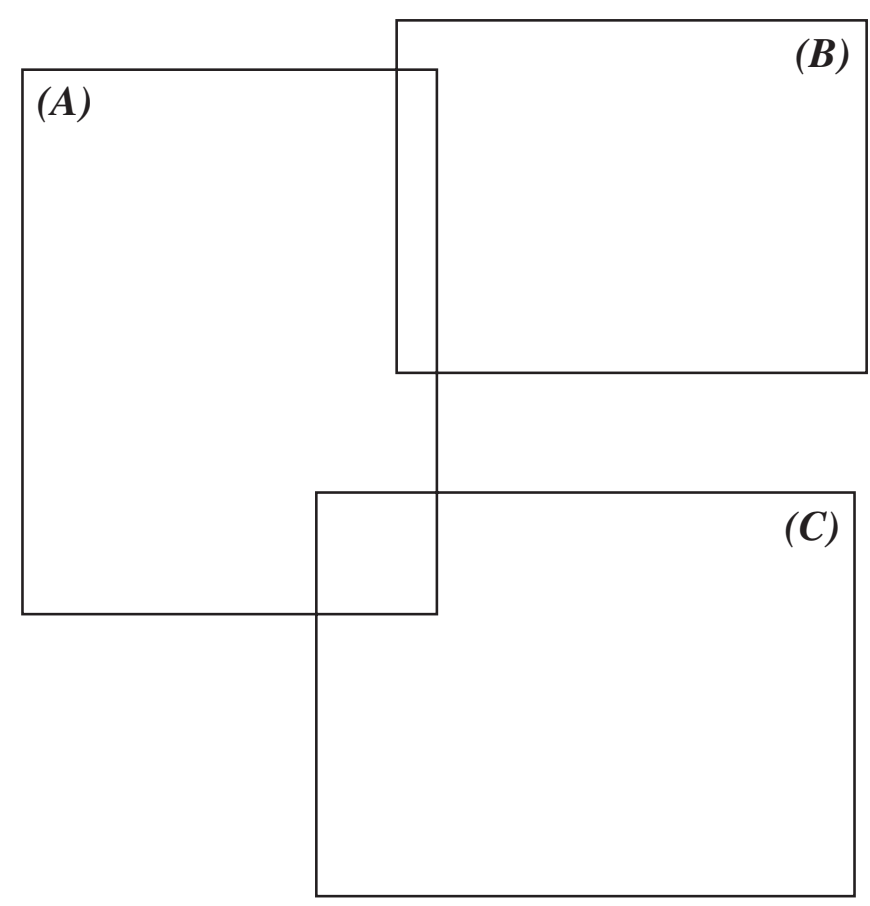

Back cover: (A)U.S. Geological Survey personnel surveying a Cardwell Branch cross section. (B) U.S. Geological Survey personnel collecting biota from woody habitat. (C) A representative stream channel in the Cardwell Branch watershed. 

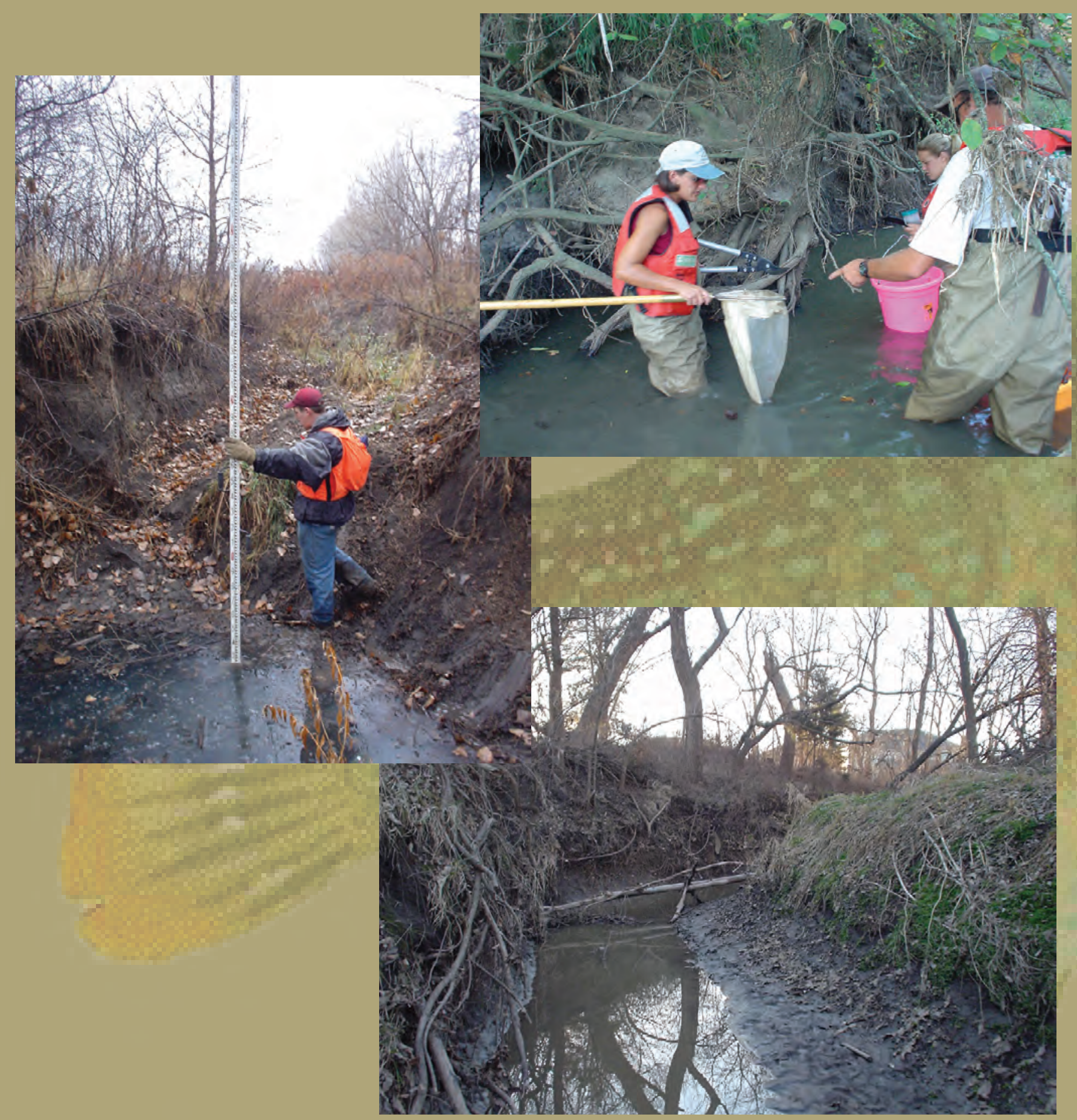

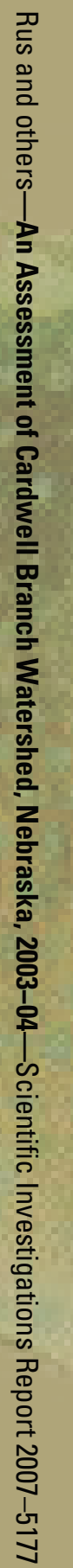

